\author{
Universidade de São Paulo \\ Faculdade de Filosofia, Letras e Ciências Humanas \\ Departamento de Geografia \\ Programa de Pós-Graduação em Geografia Humana
}

\author{
Ronaldo Gomes Carmona
}

\title{
GEOPOLÍTICA CLÁSSICA E GEOPOLÍTICA BRASILEIRA CONTEMPORÂNEA: \\ MAHAN, MACKINDER e a "grande estratégia" do Brasil para o século XXI
}

São Paulo

2012 


\section{Ronaldo Gomes Carmona}

\section{GEOPOLÍTICA CLÁSSICA E GEOPOLÍTICA BRASILEIRA CONTEMPORÂNEA: MAHAN, MACKINDER e a "grande estratégia" do Brasil para o século XXI}

Dissertação apresentada ao Programa de Pós-Graduação em Geografia Humana do Departamento de Geografia da Faculdade de Filosofia, Letras e Ciências Humanas da Universidade de São Paulo, para obtenção do título de Mestre em Geografia Humana.

Área de concentração: Geografia Humana

Orientador: Prof. Dr. André Roberto Martin

São Paulo

2012 
Autorizo a reprodução e divulgação total ou parcial deste trabalho, por qualquer meio convencional ou eletrônico, para fins de estudo e pesquisa, desde que citada a fonte.

Carmona, Ronaldo Gomes

Geopolítica clássica e geopolítica brasileira contemporânea: Mahan, Mackinder e a "grande estratégia" do Brasil para o século XXI./Ronaldo Gomes Carmona; Orientador: Professor Doutor André Roberto Martin - São Paulo, 2012.

$166 \mathrm{fls}$

Dissertação (Mestrado - Programa de Pós-graduação em Geografia Humana, Área de concentração: Geografia Humana) - Faculdade de Filosofia, Letras e Ciências Humanas da Universidade de São Paulo 
Nome: CARMONA, Ronaldo Gomes

Título: Geopolítica clássica e geopolítica brasileira contemporânea: Mahan, Mackinder e a "grande estratégia" do Brasil para o século XXI.

Dissertação apresentada ao Programa de Geografia Humana, do Departamento de Geografia da Faculdade de Filosofia, Letras e Ciências Humanas da Universidade de São Paulo, para obtenção do título de Mestre em Geografia Humana.

Aprovado em:

Banca Examinadora

Prof. Dr. Instituição:

Julgamento: Assinatura:

Prof. Dr. Instituição:

Julgamento: Assinatura:

Prof. Dr. Instituição:

Julgamento: Assinatura: 


\section{RESUMO}

País de território misto, marcado a um só tempo pela continentalidade e pela maritimidade, o Brasil tem, na análise dos clássicos da teoria geopolítica relacionados ao poder naval, na pessoa de Alfred Mahan e na teoria do poder terrestre, desenvolvida por Halford Mackinder, importantes questões para a discussão de sua visão estratégica contemporânea, num contexto em que há um importante aumento da estatura política e econômica do país no cenário mundial. Neste sentido, a presente Dissertação busca, após a revisão dos conceitos principais dos dois teóricos clássicos citados, identificar aspectos relevantes da evolução recente e das grandes tendências do cenário internacional, bem como do curso do pensamento estratégico brasileiro. Como conclusão, o estudo busca relacionar estes debates aos documentos oficiais recentes publicados na área de Defesa Nacional que esboçam a visão geopolítica e estratégica contemporânea do Brasil.

Palavras-chave: Brasil, geopolítica, relações internacionais, poder marítimo e poder terrestre

\section{ABSTRACT}

A country of mixed territory, marked both of a continental extension and by a long cost on the sea, Brazil has, in the analysis of classical geopolitical theory related to sea power in the person of Alfred Mahan and on the theory of land power, developed by Halford Mackinder, important questions for discussion of its contemporary strategic vision, in a context where there is a significant increase in political and economic stature of the country on the world scenery. In this sense, this thesis seeks after a review of the main concepts of the two classical theorists cited, identify relevant aspects of recent developments and major trends on the international scene, as well as the course of the Brazilian strategic thinking. In conclusion, the study seeks to relate these discussions to official documents published in the recent National Defense field, outlining the geopolitical and strategic vision of contemporary Brazil.

Key words: Brazil, geopolitics, international relations, sea power and land power 


\section{CAPÍTULO I}

Teoria do Poder Naval e Teoria do Poder Terrestre: apresentação sistemática do pensamento geopolítico de Alfred Thayer Mahan e Halford John Mackinder.

\section{CAPÍTULO II}

Atualidade e superações, pontos de contato e diferenças em Mahan e Mackinder.

.58

\section{CAPÍTULO III}

As grandes tendências geopolíticas da situação internacional contemporânea. 82

\section{CAPÍTULO IV}

A escola geopolítica brasileira: notas retrospectivas e contemporâneas. 107

\section{CONCLUSÕES}

A geopolítica de Mahan e Mackinder e a "grande estratégia" brasileira. 125 


\section{INTRODUÇÃO}

Extrair lições e ensinamentos dos clássicos, ou do conhecimento pretérito, para projetar variáveis para o futuro ou para buscar produzir inovações, é metodologia comum às ciências sociais e às ciências naturais. De modo geral, é a forma pela qual o ser humano acumula conhecimento e gera novos, buscando, assim, avançar no conhecimento humano nas mais diversas áreas de interesse humano.

A geopolítica, questão discutida já no primeiro capitulo, após uma emergência virtuosa no final do século XIX, início do XX, foi da proscrição e interdição no debate acadêmico a uma reemergência neste início de século XX.

Esta emergência virtuosa relacionou-se com a própria ascensão dos Estadosnações, especialmente no continente europeu. Apoiando-se na geopolítica, muitos Estados buscavam definir sua estruturação nacional, quais seus objetivos centrais e onde se localizariam no concerto das nações. Nesse contexto, alguns resvalaram para atitudes abertamente imperialistas, em especial os Estados Unidos e a Alemanha nazista.

Tais atitudes, em grande medida é creditada a orientação realista, que por definição, é a base da visão de mundo, da qual parte a geopolítica, fazendo então iniciar um período de interdição e prescrição, especialmente na academia, ainda que as escolas e os centros de estudos estratégicos ligados às Forças Armadas, em todo o mundo, continuassem, em maior ou menor medida, estudando-a e aplicando-a em sua orientação cotidiana e em suas análises prospectivas.

As abruptas mudanças no quadro internacional no final do século $\mathrm{XX}$, entretanto, tiveram efeitos de grande importância nas relações internacionais e na própria visão das nações acerca de sua inserção internacional.

Primeiro, pela euforia liberal do início dos anos 1990, provocado pela vitória de "um dos lados" na contenda da guerra fria, após mais de meio século de forte embate, não apenas ideológico como também político, científico-tecnológico, econômicofinanceiro e estratégico-militar. Disseminou-se então, como orientação hegemônica no mundo, teses que defendiam a diminuição do papel do Estado, no que, obviamente, teria como consequência num desuso das orientações geopolíticas. 
Entretanto, a embriaguez dos vencedores durou pouco e a unipolaridade não tardou para se chocar com os mais diversos interesses nacionais, e, assim, logo uma tendência a multipolaridade, não tardou a se estabelecer com a emergência, portanto, de polos e atores estatais que buscavam "seu lugar ao sol" no sistema internacional.

Assim, com passos largos a multipolaridade e com a reemergência dos Estadosnações - e mais amplamente, do interesse nacional - iniciamos o século XXI, que, no momento em que redigimos estas notas, já entra para sua segunda década. Momento propício, portanto, para a reemergência das teorias geopolíticas, que voltam a ser instrumento de análise na academia.

Num contexto em que o Brasil começa a deixar para trás seu famoso "complexo de vira-lata" - expressão de Nelson Rodrigues, popularizada pelo presidente Lula, em suas referências à política externa -, e, assim, emerge como um dos importantes atores no cenário internacional, a retomada dos preceitos geopolíticos, sobretudo os clássicos, pode jogar alguma luz sobre a discussão acerca de uma "grande estratégia" que se esboça em nosso país. Esboço, digamos, que todavia necessita ajustes e precisões.

Ao mesmo tempo, o horizonte temporal de implementação das medidas que se anunciam é relativamente largo, cerca de vinte anos, aproximadamente. Se por um lado isto não é de todo ruim, uma vez que parece termos voltado a ter alguma capacidade de planejamento de longo prazo, por outro a urgência da superação do hiato entre o crescente poder político e econômico do país e sua baixa estatura estratégico-militar é um problema "para ontem".

Na presente Dissertação, dada a evolução recente da geopolítica, do mundo e do próprio Brasil, que acabamos de descrever de forma breve, pareceu-nos adequado retomar as grandes teses defendidas por dois dos geopolíticos de maior envergadura e consistência que se apresentam, cujos argumentos, em boa parte, seguem vigentes e é base para orientações estratégicas por parte de diversos Estados nacionais.

Assim, começamos nosso CAPÍTULO I, denominado "Teoria do Poder Naval e Teoria do Poder Terrestre: apresentação sistemática do pensamento geopolítico de Alfred Mahan e Halford Mackinder". 
Aqui se poderá observar um painel que busca ser o mais completo possível na revelação das principais teses destes dois pensadores clássicos. Embora sejam teses muito estudadas, sobretudo nas cadeiras de geografia política dos Departamentos de Geografia das boas Universidades, mundo a fora, sistematizar estas teses nesta Dissertação tem o objetivo de indicar os pontos de partida que repercutirão no conjunto do estudo.

O CAPÍTULO II também é autoexplicativo por seu título, denominando-se “Atualidade e superações, pontos de contato e diferenças em Mahan e Mackinder".

Trata-se aqui, primeiramente, de justificar o uso destes clássicos, observando o que se mantém, o que está defasado, datado. E junto à isso, observar como os autores dialogam e quais os pontos em que apresentam diferenças eventualmente irreconciliáveis.

Estes dois primeiros capítulos pretendem, portanto, ser uma introdução sistemática ao pensamento dos dois autores, visando alicerces sólidos para avançar em nosso estudo.

Na sequência, temos o CAPÍTULO III - "As grandes tendências geopolíticas da situação internacional contemporânea”. É preciso agora, pois, fixar uma análise para aonde caminha o mundo, o que virá por aí, tendo como base um estudo de conjuntura e avaliações prospectivas, sendo utilizado, para tanto, documentos e pronunciamentos das grandes nações e ao mesmo tempo tendências apontadas por importantes acadêmicos e analistas das relações internacionais.

Já no CAPÍTULO IV, intitulado "Escola geopolítica brasileira: notas retrospectivas e contemporâneas", buscamos, ainda que de forma relativamente pontual, observar o curso histórico e contemporâneo do que podemos denominar como pensamento estratégico brasileiro, no sentido de apresentar sistematicamente seu curso e seu estado atual.

E para finalizar, desenvolvemos as CONCLUSÕES desta Dissertação, as quais denominamos de "A geopolítica de Mahan e Mackinder e a "grande estratégia" brasileira". 
Nesta parte final, relacionamos todo o debate teórico anterior, seja das grandes teses de Mahan e Mackinder, seja das tendências da situação internacional ou do curso do pensamento estratégico nacional às elaborações recentes de documentos que, como dissemos, esboçam linhas gerais da "grande estratégia" brasileira: o Livro Branco de Defesa Nacional (2012), a Estratégia Nacional de Defesa (2008 e 2012) e a Política Nacional de Defesa (2012) - antes, Política de Defesa Nacional, 1996 e 2005).

A opção pelos citados documentos, a despeito da impossibilidade do sempre recomendável distanciamento histórico, se dá, sobretudo, para que o presente trabalho acadêmico tenha a função de representar uma contribuição ao grande debate que se apresentará no Brasil, na medida em que o país eleve sua estatura no concerto das nações.

São Paulo, novembro de 2012. 


\section{CAPÍtULO I}

\section{Teoria do Poder Naval e Teoria do Poder Terrestre: apresentação sistemática do pensamento geopolítico de}

Alfred Thayer Mahan e Halford John Mackinder

O presente capítulo busca apresentar sistematicamente uma introdução ao pensamento geopolítico clássico, por meio do principal interprete da teoria do poder naval e do autor principal da teoria do poder terrestre, respectivamente, Alfred Mahan e Halford Mackinder.

Iniciamos com a apresentação das definições correntes de geopolítica para num segundo momento discorrermos sobre os fundamentos do pensamento de Mahan, seguido de Mackinder.

Para os propósitos da presente Dissertação, consideramos fundamental partir destas definições, visando assentar as bases teóricas a partir das quais buscamos avançar para o debate sobre atualidade dos dois autores, seguida de digressões sobre o cenário geopolítico e geoestratégico mundial, do curso do pensamento estratégico brasileiro e, finalmente, das implicações para a definição da "grande estratégia" brasileira - objeto, respectivamente, do segundo, terceiro e quarto capítulos e das conclusões.

\section{Conceituando epistemologicamente a Geopolítica}

Ao iniciarmos nosso primeiro capítulo constamos que há atualmente certa banalização do uso do termo geopolítica. Como argumenta MARTIN:

quando os noticiários apresentam qualquer chefe de governo ou chanceler justificando determinada decisão em política externa porque apoiada em razões 'geopolíticas' ou 'geoestratégicas', tal ato imediatamente parece adquirir a aura de uma sentença científica, não dando margem a nenhuma contestação (MARTIN, 2007, p. 08). 
Já COSTA (2008, p. 55), argumenta que "devido à confusão conceitual e terminológica que se estabeleceu em torno da definição de geopolítica", faz-se necessária dirimir a natureza conceitual da geopolítica.

Para ele,

a geopolítica, tal como foi exposta pelos principais teóricos, é antes de tudo um subproduto e um reducionismo técnico e pragmático da geografia política, na medida em que se apropria de parte de seus postulados gerais para aplicá-los na análise de situações concretas interessando ao jogo de forças estatais projetados no espaço (COSTA, 2008).

Segundo VESENTINI,

a partir do final da década de 1980 , devido às mudanças radicais no mapa-
múndi (vistas pela mídia, com razão, como redefinções geopolíticas), a
palavra geopolítica tornou-se moda. Hoje ela é usada, em alguns meios, para
se referir a praticamente todas as discussões políticas e econômicas
internacionais - os encontros relativos ao meio ambiente global, as reuniões
da OMC ou do FMI e os protestos contra eles, a ALCA ou a União Européia
etc. -, algo que evidentemente torna esta palavra desprovida de qualquer
significado preciso (VESENTINI, 2008, p. 10).

Mas, para além do uso quase coloquial do termo geopolítica, o fato é que, como argumenta MARTIN (2007, p. 06), "a luta pelo controle dos recursos naturais finitos vem se intensificando de tal maneira, que já se prenuncia uma onda de reabilitação e revalorização da centenária disciplina, apelidada por alguns de "ciência demoníaca"”. Eis um dado objetivo da realidade atual e que pede a revisitação do pensamento clássico da geopolítica, sintetizado nos dois autores que apresentamos a seguir, que pensamos, ajudarão a demonstrar esta "reabilitação e revalorização".

Atribui-se o uso original do termo geopolítica ao professor sueco Rudolf Kjéllen, tido como um germanófilo - pois é considerado discípulo de Ratzel e partidário das teses expansionistas alemãs - e professor de direito político nas Universidades de Gotemburgo e Upsala.

Rudolf Kjéllen filiava-se a visão organicista da geografia, segundo a qual o Estado se assemelha a um organismo biológico, em constante expansão ou, caso contrário, tenderá à morte. Como diria o próprio Kjéllen, "como tal" (organismos biológicos) "os Estados estão sujeitos a leis do crescimento". Assim, "os Estados 
vigorosos e cheios de vida que possuem um espaço limitado obedecem ao categórico imperativo de expandir seu espaço, seja por colonização, amalgamação ou conquista" (COSTA, 2008, p. 57).

Não é por acaso, portanto, segundo continua COSTA, "o sucesso de suas ideias junto aos círculos de poder de diversos países", incluindo os regimes fascistas europeus e "ambientes militares do Terceiro Mundo", numa visão que "pelo estilo e conteúdo, os artifícios e manipulações conceituais de Kjéllen mais se assemelham a um receituário de imperialismo". Cabe ponderar, entretanto, que este não é o propósito nem historicamente nem hodiernamente do Brasil, como veremos ao longo desta Dissertação.

País satisfeito territorialmente, a teoria geopolítica faz sentido, ontem e hoje para o Brasil, na salvaguarda de sua integridade e independência nacional.

Para Kjéllen, "geopolítica é a ciência do Estado como organismo geográfico e, significadamente, como soberania", segundo transcreve Vicens-Vives (MIYAMOTO, 1995, p. 22).

Entretanto, a despeito de ser o pioneiro no uso do termo geopolítica, podemos dizer, ao investigar o conteúdo do conceito, que não terá sido Kjéllen o primeiro geopolítico. Mahan, por exemplo, como veremos a seguir, foi um geopolítico por excelência, a despeito de à época, ainda não se utilizar tal categoria - mas certamente seu conteúdo em muito se se aproxima deste conceito. No Brasil, aquele que nos parece ser nosso primeiro e quiçá o maior geopolítico de nossa história, tendo em vista seu papel na conformação de nosso território, o patriarca José Bonifácio de Andrada e Silva, tampouco seria comunmente denominado como tal.

Passemos a outras definições conceituais de geopolítica.

Nesse contexto, Karl Haushofer, da Escola de Munique, afirmava que:

a geopolítica é a ciência que trata da dependência dos fatos políticos em relação ao solo. Apóia-se sobre as amplas bases da geografia, em especial da geografia política, doutrina da estrutura espacial dos organismos políticos (...). A geopolítica aspira a proporcionar as armas para a ação política, e os princípios que sirvam de guia na vida política. A geopolítica é a base da atuação política, na luta de vida ou morte dos organismos políticos pelo espaço vital (transcreve Weigert, apud MIYAMOTO, 1995, p. 22). 
O geopolítico norte-americano Hans W. Weigert, a propósito, afirma que:

a geopolítica é a geografia política na política do Poder Nacional e sua estratégia na paz ou na guerra (e) ao relacionar todo desenvolvimento histórico com as condições de espaço e solo (e) ao considerar a história determinada por estas forças eternas, a geopolítica tenta predizer o futuro (WEIGERT, apud MIYAMOTO, 1995, p. 22).

O mesmo Hans W. Weigert tem grande mérito ao defender a tese da existência de múltiplas geopolíticas, diferenciadas segundo objetivos estratégicos nacionais. Esclarece que:

\begin{abstract}
não existe algo como uma ciência geral da geopolítica, que possa ser subscrita por todas as organizações estatais. Há tantas geopolíticas quantos os sistemas estatais em luta sob condições geográficas, as quais, no caso do poder marítimo e do poder terrestre são fundamentalmente diferentes. Há uma "Geopolitik", uma "geopolitique" [...] Cada nação tem a geopolítica que pretende [...] Assim sendo, temos de olhar para a Geopolítica alemã como produto de um povo envolvido numa luta pelo domínio mundial (WEIGERT, 1942, p. 22-23).
\end{abstract}

Segundo Yves Lacoste, "o termo geopolítica, utilizado em nossos dias de múltiplas maneiras, designa na prática tudo relacionado com as rivalidades pelo poder ou a influencia sobre determinados territórios e suas populações" (LACOSTE, 2008, p. 08).

No Diccionario latinoamericano de seguridad y geopolítica, encontramos a seguinte definição para o verbete que trata de geopolítica:

área de análise multidisciplinar das ciências sociais que estuda a influência dos fatores geográficos na vida e na evolução dos Estados, a fim de extrair conclusões de caráter político que sirvam de guia ao estadista na condução da política interna e externa do Estado (BARRIOS, 2009, p. 193).

Com o mesmo sentido, no mesmo Dicionário (2009, p. 195), tem-se o estrategista norte-americano Zbigniew Brzezinki recordando que "se diz que Napoleão afirmou certa vez que reconhecer a geografia de um país equivale a conhecer sua política exterior".

Vale lembrar, ainda, uma máxima consagrada a Napoleão, que em 1804 afirmava que "la politique de toutes les puissances est dans leur geographie" (a politica de todas as potências está em sua geografia). 


\section{Algumas definições de autores brasileiros sobre geopolítica.}

O General Golbery do Couto e Silva, em sua obra clássica Geopolítica do Brasil, sustenta que:

para nós, a Geopolítica nada mais é que a fundamentação geográfica de linhas de ação política, quando não, por iniciativa, a proposição de diretrizes políticas formuladas à luz dos fatores geográficos, em particular de uma análise calcada, sobretudo, nos conceitos básicos de espaço e de posição (COUTO E SILVA, 1967, p. 64).

Para ele, a geopolítica é "um dos ramos, portanto, da política, como a imaginava o próprio Kjéllen e sempre a qualificou, e entre nós, o mestre Backheuser: 'política feita em decorrência das condições geográficas"” (1967, p. 64).

O General Meira Mattos diz que "em termos genéricos entendemos geopolítica como 'a política aplicada aos espaços geográficos"”. Para ele, "este conceito, por sua amplitude, cobre todos os demais, com o mérito de evitar a polêmica retórica sobre o assunto" (1984:3). Segundo o referido general, “o mais sintético e abrangente conceito de Geopolítica é de Ratzel: “espaço é poder”” (MEIRA MATTOS, 1975, p. 5).

Segundo Therezinha de Castro:

ciência da vinculação geográfica dos acontecimentos políticos, a Geopolítica tem por objetivo principal o aproveitamento racional de todos os ramos da geografia no planejamento das atividades do Estado, visando a resultados imediatos ou remotos. Em razão disto, a Geopolítica pode ser considerada como um estudo dos precedentes históricos em função dos ambientes geográficos; os resultados destes estudos levam a conclusões práticas, aplicáveis ou não à atualidade (CASTRO, 1999, p. 23).

Dada as características acima observadas, é comum a crítica - sobretudo em determinadas correntes contemporâneas, especialmente as de viés pós-moderno - acerca de uma natureza estadocêntrica da geopolítica - como denominou Raffestin (apud COSTA, 2008). Mas para efeito deste trabalho - que busca analisar a pertinência de análises da geopolítica clássica, e não do que poderíamos denominar como "novas geopolíticas", como argumenta o livro de Vesentini - não entraremos nesse debate. Ainda assim, cabe ressaltar, nosso pressuposto é a continuidade da centralidade do Estado como ator determinante no cenário internacional.

Vale dizer, como apresenta a geógrafa Berta BECKER, que: 
apoiada nos princípios do paradigma do realismo político, a geopolítica reforça a tradição político-geográfica dos estudos focados no Estado. Mais do que isto, de fato, os estudos geopolíticos clássicos reconhecem o Estado como o único protagonista das relações internacionais, depreendo-se desse reconhecimento à idéia de que o Estado é a única fonte de poder". Segundo ela, a máxima de Ratzel - "espaço é poder" - "abre um fértil caminho para análises que vinculassem as ações do Estado com a organização do espaço (BECKER, 2010, p. 147-148).

Berta Becker também define - de forma que nos parece muito apropriada -, um vínculo estreito entre a escola realista ou clássica e a geopolítica. Para ela, o realismo é o "balizador da geopolítica clássica".

Aqui, cabe recordar os seis princípios da teoria realista, sistematizado por Hans J. Morgenthau, em seu clássico A Política entre as Nações (2003, p. 4-28) - para se perceber o quanto é correta a afirmação acerca deste estreito vínculo. Utilizemos para tal, a síntese de Berta BECKER (2010, p. 148):

1) A política, tal como a sociedade é governada por leis objetivas, comparáveis à luta pela sobrevivência, refletindo-se na conduta dos Estados;

2) Todo e qualquer interesse - político, econômico ou cultural - dos atores internacionais deve ser traduzido na pretensão de alcançar mais poder;

3) O conceito-chave de interesse definido como poder é uma categoria objetiva com validade universal;

4) Não existem regras morais universais aplicadas a todas as situações e ações dos Estados;

5) O sistema internacional é absolutamente anárquico, isto é, desprovido de qualquer regulação supranacional;

6) Consagra a separação entre política interna e política externa dos Estados, ou seja, é o "império dos mais fortes".

A Geopolítica logo se dividiria em duas escolas: a determinista e a possibilista. Segundo nos explica Meira Mattos, 
determinista foi chamada a Escola alemã, porque defendia a tese de que $a$ geografia determina o destino dos povos, enquanto a escola possibilista, que teve como principal porta-voz o geógrafo Frances Vidal de la Blanche, ancorava-se na ideia de que a geografia possibilita soluções favoráveis ao destino dos povos (MATTOS, 1975, p. 3).

Ainda quanto ao debate epistemológico acerca da conceituação de geopolítica, cabe ver que COSTA $(2008$, p. 58) chama atenção para o fato dos primeiros estudos de geopolítica saudar as teses de Kjéllen por este haver operacionalizado os fundamentos de Ratzel, com uma "nova ciência", antes de tudo dinâmica - em contraponto a natureza supostamente estática da geografia política.

COSTA também registra o aparecimento da geopolítica como produto do contexto europeu da virada do século XIX para o XX. No plano geral, também atendia a uma tendência da época:

\footnotetext{
à relação entre espaço e poder (...) num momento histórico que envolvia o mundo em escala global, caracterizado pela emergência das potencias mundiais, e com elas, o imperialismo como forma histórica de relacionamento internacional (COSTA, 2008).
}

O autor apresenta, a seguir, a definição clássica de imperialismo em Vladimir Lênin (em O Imperialismo, fase superior do capitalismo), na qual o comunista russo apresenta a primeira guerra mundial como exemplo de "uma guerra imperialista (isto é, uma guerra de conquista, de bandidagem e de rapina), uma guerra pela repartição do mundo, pela distribuição e redistribuição das colônias, das 'esferas de influência' do capital financeiro etc." (apud Costa, 2008, p. 59-60). Parece-nos que a sofisticação da teoria do imperialismo de Lênin é apontada por "não se tratar simplesmente de 'conquista territorial', mas de competição entre Estados associados aos grandes monopólios". Assim, situa-se a fase imperialista com a própria evolução do modo de produção capitalista ou à dinâmica capitalista do mundo.

COSTA (2008, p. 63) também observa, dando razão a Mackinder, como veremos mais a frente, que a exceção do Japão - e acrescentemos, dos Estados Unidos -, todos os demais Impérios "caracterizavam-se basicamente pela concentração de suas políticas territoriais na vasta massa terrestre compreendida pela Eurásia”, pelo que, "suas fronteiras formais e aquelas que separavam as respectivas áreas de influência constituíam autenticas linhas de fricção e tensão, transformando essa região do globo 
num vasto campo de conflitos potenciais". Esse dado da realidade - disputas interimperialistas, como diria Lênin, na virada do século XIX para o XX - certamente inspirou Mackinder a formular sua teoria geopolítica.

Por fim, outro fator introdutório relevante para a compreensão da teoria geopolítica clássica, é a emergência dos Estados Unidos da América como grande potencia global no final do século XIX, cujo "desenvolvimento histórico foi pleno de notáveis particularidades" (COSTA, 2008, p. 64-65).

Afinal, os EUA surgem, desde sua independência em 1776, com todo seu empenho "concentrado no alargamento permanente de seu território original", no que daria razão aos organicistas. Assim, esta expansão geopolítica ao estilo preconizado pelos organicistas, o combustível ideológico era a ideia de Destino Manifesto, ou seja, a visão de mundo baseada na crença de um papel civilizador dos bárbaros por inspiração ou mesmo determinação divina, que justificava guerras e expansões tipicamente imperialistas. Isso se vê muito claramente nas justificativas de Mahan.

Com a expansão norte-americana e, em especial, com sua formulação básica de política externa a respeito da América para os americanos - forma de impedir a ingerência europeia sob seus "domínios" -, diz COSTA (2008, p. 68), replicando Mackinder, "o quadro geopolítico mundial estava completo". Afinal, "o mundo agora estava dividido por áreas de influência de cada uma" das potências mundiais.

Essa ideia pois, replica a ideia basilar de Mackinder, a qual sustenta que a virada do século XIX para o XX observou a emergência de um sistema político fechado, no qual todas as latitudes já estavam com um poder político estabelecido.

Assim, estavam dadas as condições, na qual "se desenvolverá a "nova geografia política' e a sua vertente aplicada às estratégias de domínio e de guerra, a geopolítica”. 


\section{As teses principais de ALFRED THAYER MAHAN}

Alfred Thayer Mahan nasceu em 27 de setembro de 1840, na cidade de West Point e viveu até dezembro de 1914. Era filho de um militar, professor da Academia Militar de West Point e de uma professora, ambos protestantes e profundamente religiosos, o que impactaria bastante sua visão de mundo.

É tido como o principal teórico do poder estratégico naval, tendo produzido teses geopolíticas, que como veremos, tiveram importantes consequências, seja para o expansionismo de seu país, os Estados Unidos, seja para fornecer argumentos favoráveis à expansão e fortalecimento das Armadas em distintas partes e em distintos períodos.

Num conhecido artigo sobre Mahan, Margaret Tuttle Sprout o qualifica como evangelista do poder marítimo, pois, segundo ela, "nenhuma outra pessoa influenciou tão direta e profundamente a teoria do poder marítimo e a estratégia naval como Alfred Thayer Mahan"1.

A importância de suas ideias é reconhecida por muitos estudiosos. Sua originalidade no período moderno é ressaltada por COSTA (2008, p. 68-69), para quem Mahan "é reconhecido como o precursor das teorias geopolíticas sobre o poder marítimo na época contemporânea".

Diz MELLO (1999, p. 15), que "na virada do século, o Sea Power, de Mahan, tornou-se a bíblia dos defensores do destino manifesto estadunidense e dos partidários da política de expansão do poderio naval norte-americano".

Para ALMEIDA (2010, p. 157) "é certo que Mahan não tinha conhecimento dessa nova disciplina (a geopolítica) que só seria sistematizada por Kjéllen 26 anos depois de seu clássico". Entretanto, pelo conteúdo de sua teoria, afirma CASTRO (1999, p. 106), "Mahan foi um dos precursores da geopolítica”.

\footnotetext{
${ }^{1}$ ALMEIDA, Francisco Eduardo Alves de. Alfred Thayer Mahan: o homem. Revista Marítima Brasileira (RBM), Região, p. 147-173, 2ำ trimestre de 2009.
} 
Interessante observar, que dois dos maiores protagonistas de geopolítica, que neste trabalho serão estudados, escreveram antes do aparecimento formal da disciplina como tal, com Rudolf Kjellén (1864-1922), um político e acadêmico sueco.

Explicita ALMEIDA que:

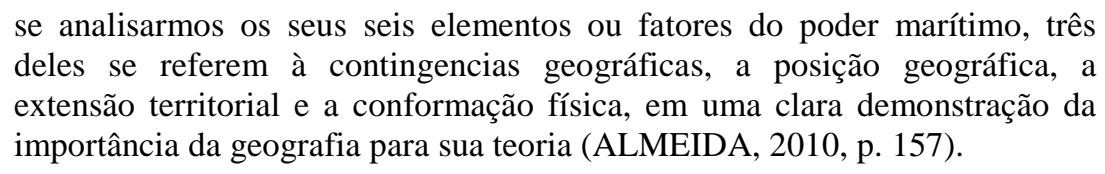

Como dissemos acima, a importância de Mahan para os estudos geopolíticos contemporâneos são ainda maiores tendo em vista seu papel precursor na teorização e na fundamentação da expansão norte-americana - dentre outros aspectos, por encargo divino, justificaria ele em sua arraigada crença conservadora protestante.

De fato, foi em torno da época em que viveu e escreveu Mahan o antecedente histórico imediato do período em que esse país elevou seu status à categoria de grande superpotência e que é concluído de fato - ou melhor, iniciado plenamente -, ao final da segunda grande guerra mundial.

Assim, pode-se dizer que o pensamento de Mahan foi base para os Estados Unidos transitarem à categoria de país hegemônico. Sua teoria aparece sob medida para o projeto de expansão imperialista estadunidense. 


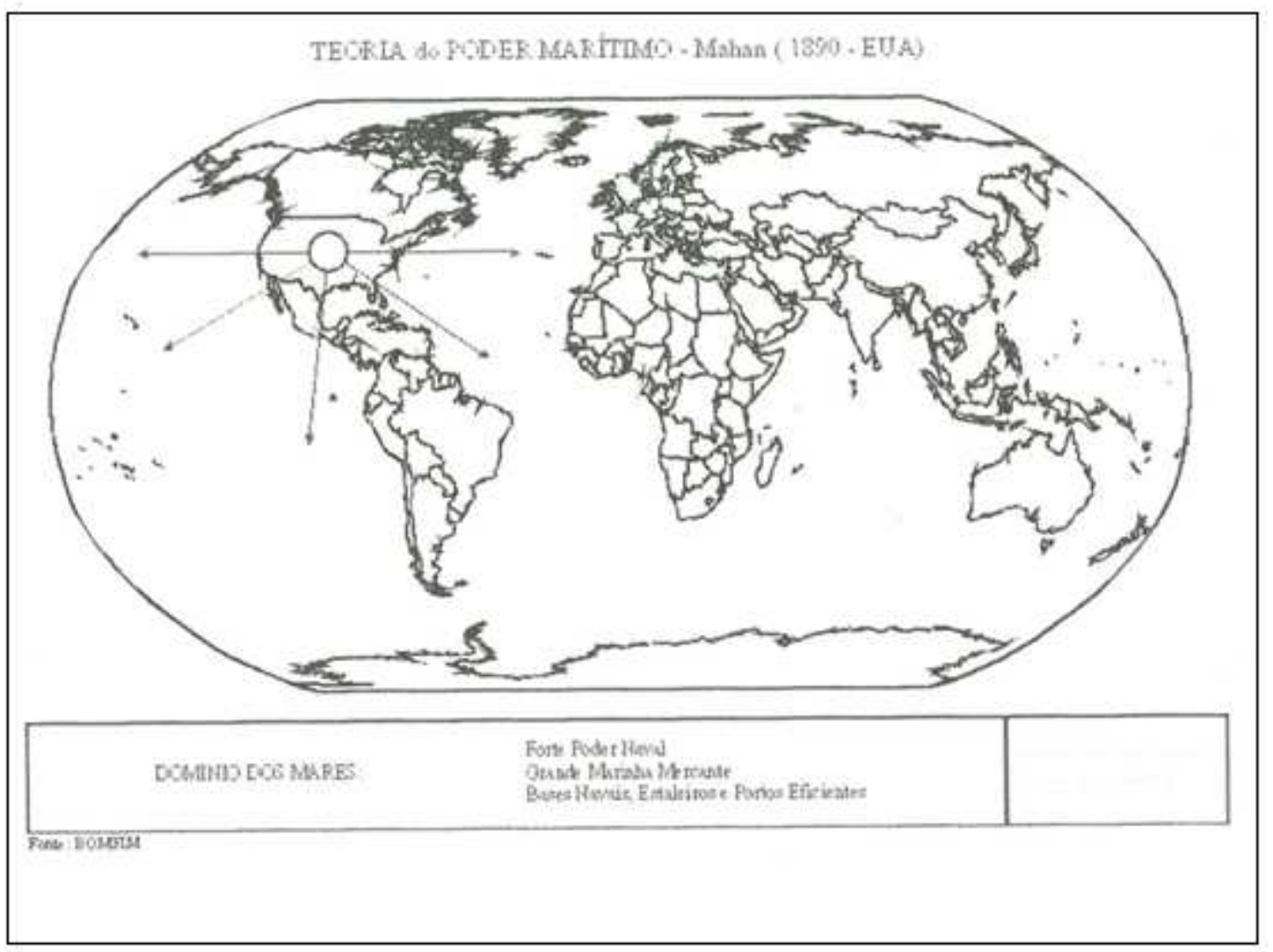

MAPA 01: BONFIM, Uraci Castro. Geopolítica. Brasília: Escola de Comando e EstadoMaior do Exército, 2005. p. 57.

Argumenta COSTA, que se em Ratzel, a geografia política é examinada, a partir de certa "óptica alemã", com Mahan, surge uma "óptica norte-americana", a partir de sua obra clássica The influence of sea power upon history: 1660-1783, publicada em 1890. Assim, Mahan foi considerado um "filósofo naval do imperialismo"2.

Como instrutor de história naval e estrategista da Escola de Guerra Naval, entre 1886 e 1893, Mahan iniciou a produção de volumosa obra, composta por diversos livros ${ }^{3}$.

Mas foi The influence of sea power sua principal obra. Nela, realizou "um estudo sistemático da história naval, centrando suas pesquisas nos séculos XVII e XVIII,

${ }^{2}$ Cf. MORISON; COMMAGER, apud COSTA, 2008, p. 69.

${ }^{3}$ Entre os quais, The Gulf and Inland Waters (1883); o próprio The Influence of sea power upon history, 1660-1783 (1890); The life of Nelson: the embodiment of the sea power of great Britain (1897); Lessons of the war with Spain, and Other articles (1899); e o ultimo, The major operations of the navies in the war of American independence (1913). 
procurando, assim, analogias entre as guerras terrestres e navais, de modo a constituir uma teoria da tática naval”4.

O plano da obra compõe-se de uma introdução e quatorze capítulos, no qual, após analisar The elements of sea power, Mahan passa em revista grandes batalhas navais da história, que vai da segunda guerra anglo-holandesa à sucessão espanhola, passando pelo Nilo, Copenhagen e Trafalgar.

A partir da análise histórica, essencialmente, "desde o início de sua proposição, Mahan procurou enfatizar a centralidade do mar nos destinos das nações". Assim, "sua obra teve impacto imediato no meio naval, principalmente na Grã-Bretanha (...) os ingleses se abismaram por ter sido um norte-americano e não um britânico que melhor descrevera as políticas navais inglesas da época”. (ALMEIDA, 2009, p.156)

Contudo, ainda que a obra, a despeito deste comentário, tenha sido altamente funcional à sustentação teórica da expansão imperialista norte-americana - como veremos -, "sem perceber, Mahan proveu de argumentos os políticos ingleses que desejavam a expansão britânica no mar". Também na Alemanha, "o livro foi um retumbante sucesso. O kaiser, ao ler a obra de Mahan, percebeu o respaldo necessário para a expansão colonial de sua nação e o desenvolvimento de um forte poder marítimo, de modo a contestar o poder da Grã-Bretanha" (ALMEIDA, 2009a, p. 155-157).

Mahan busca sistematizar leis gerais para os princípios acerca das operações navais. Para ele,

o teatro de guerra pode ser maior ou menor, suas dificuldades mais ou menos pronunciadas, as armadas maiores ou menores, os movimentos necessários mais ou menos fáceis, mas estas são simplesmente diferenças de escalas, de grau, não de tipo

Segundo o norte-americano, desde Hermócrates, há 2.300 anos,

os princípios, a natureza e as funções da marinha de guerra são os mesmos, cabendo-lhes a definição dos 'pontos de concentração', 'depósitos de munições e suprimentos', a 'comunicação entre esses pontos e a base original', o 'valor militar do comércio' e o modo pelo qual esse 'comércio combinado com as operações' pode ser conduzido" (MAHAN, apud COSTA, 2008, p. 69).

\footnotetext{
${ }^{4}$ Sprout apud ALMEIDA (2009a:155). Se Mahan tivesse conhecimento - improvável que tivesse - o autor poderia citar a épica batalha naval de 1613, comandada por Jêronimo de Albuquerque (1548-1618), que guiando 100 homens nos "caravelões", partindo do Recife, expulsou os franceses do Maranhão (LBDN, 2012, p. 78 e 79).
} 
Aqui, percebe-se como são constantes os grandes ensinamentos táticos e estratégicos.

\section{Os elementos do poder marítimo}

A síntese e o núcleo do pensamento mahaniano está no capítulo The elements of sea power (1984, p. 30-67), no qual ele apresenta os seis principais elementos, fatores ou condições, que poderiam afetar o poder marítimo de uma nação ${ }^{5}$. Nesta sistematização, encontram-se ensinamentos perenes, que têm sido objeto de aplicação na orientação de Armadas ao longo de décadas por todo o mundo.

\section{O primeiro elemento é a posição geográfica}

Para ele, países insulares, como a Inglaterra - e por analogia, o hemisfério americano em relação a Eurásia -, possuíam vantagens geográficas em relação a países continentais, como a França e a Holanda.

Para Mahan, se uma nação não está obrigada a defender-se por terra, "nem induzida a pensar em ampliar seu território de igual maneira”, isto é, via terrestre, pode voltar sua atenção para o mar. Assim, ele situa uma vantagem comparativa da Inglaterra em relação à Holanda e a França, países sempre ameaçados por um ataque a partir de suas fronteiras.

No caso brasileiro, carregamos nesta questão a herança de Alexandre Gusmão (1695-1753), negociador do Tratado de Madri de 1750 e do Barão do Rio Branco

\footnotetext{
${ }^{5}$ Para desenvolver "os seis elementos do poder marítimo", apoiamo-nos nos originais de MAHAN (1984), a nossa fonte primária, utilizando para isto publicação em língua inglesa, uma vez que não há tradução ao português. Como fontes secundárias, utilizamos trechos que tratam do autor na obra de COSTA (2008), e em "Alfred Mahan e os elementos do poder marítimo (III)". O texto faz parte de uma série de cinco artigos publicados em cinco edições da tradicional Revista Marítima Brasileira, entre os volumes 129, n. 04/06 (abr./jun./2009) e 130, n. 04/06 (abr./jun./2010).
} 
(1845-1912), personagens em nome de quem podemos creditar nossa "despreocupação" nacional de problemas relacionados à fronteira terrestre ${ }^{6}$.

Segundo COSTA (2008, p. 71), a configuração insular inglesa, com seus portos protegidos, faz com que "comércio marítimo, domínio colonial e poder naval formem um todo harmônico, verdadeiro modelo de poder marítimo”. Já a França, além do temor de um ataque por terra, do ponto de vista do poder naval, fazia sua esquadra dispersar-se em duas frentes, no Atlântico, ao norte - onde ademais, defrontava-se com o litoral de seu rival britânico -, e a Mediterrânea, ao sul. Para unir suas duas esquadras - em Brest e em Toulon - era obrigada "a contornar permanentemente a Península Ibérica por Gibraltar (controlado pelos ingleses)", numa clara demonstração de vulnerabilidade.

Aqui, Mahan vê uma evidente analogia com a posição do território dos Estados Unidos, igualmente dividido entre a costa Atlântica e do Pacífico. Chama atenção a centralidade, na questão relativa à posição geográfica, que "de tal natureza, requeira uma concentração ou dispersão de forças navais" (MAHAN, 1984, p.33).

Por certo, no caso brasileiro, com longo litoral disposto no sentido norte - sul sem interrupções que afetem significativamente o fluxo naval - tal preocupação não se aplica. Entretanto, dada sua centralidade no esquema de explicação da questão da posição geográfica em Mahan, cabe destacá-lo.

Afinal, tendo em vista a evidência desta condicionante geográfica na condição norte-americana - com um litoral cindido entre o Atlântico e o Pacífico -, Mahan propõe uma saída que, podemos dizer, repercute imediatamente, e mesmo até os dias de hoje. Ele defende como vital para os Estados Unidos, o controle do Caribe e, assim, do Istmo do Panamá. Mais a frente, como veremos, há a preocupação de Spykman relacionada ao norte da América do Sul, no que se localiza em chave similar relacionada ao pensamento estratégico.

Para Mahan, é essencial a construção do Canal do Panamá $^{7}$ para superar a vulnerabilidade estratégica da armada norte-americana. No que diz respeito ao controle

\footnotetext{
${ }^{6}$ Atualmente, os problemas de fronteira se referem menos a questões de natureza militar, e mais a questões relacionadas à segurança pública.

7 As teses de The influence of sea power [...] a este respeito, certamente influenciaram Teodore Roosevelt, um declarado entusiasta do livro de Mahan, a buscar, por todos os meios, efetivamente realizar a obra de abertura do Canal do Panamá - realizada, diga-se, anos após o
} 
do Caribe, três lugares seriam fundamentais: primeiro, o controle da boca do Rio Missisipi, próximo a Pensacola; segundo, a Zona do Canal do Panamá; por fím, conformando um Triângulo de defesa desta região, uma posição próxima a Ilha de Santa Lúcia.

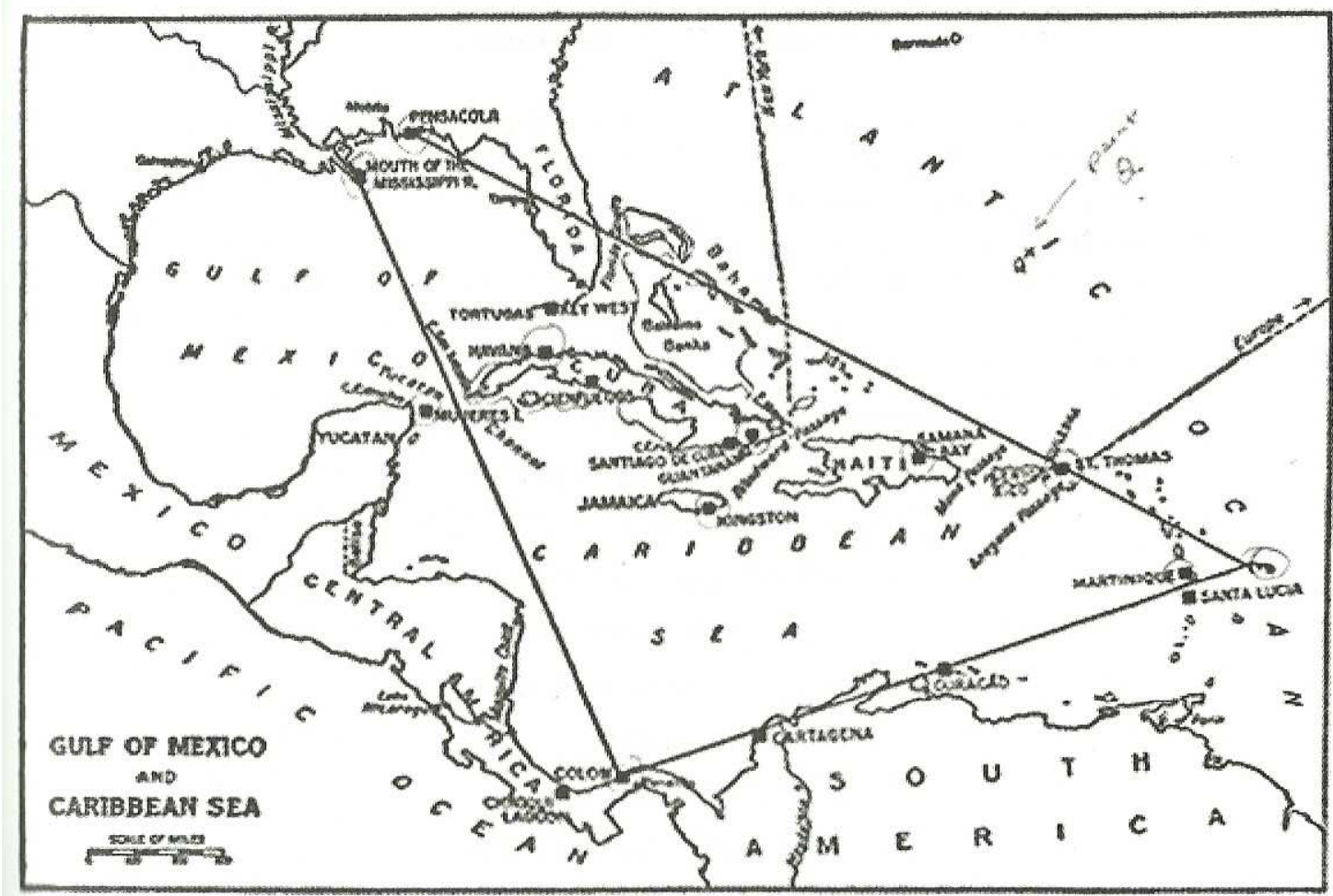

MAPA 02: ALMEIDA (2010). Alfred Thayer Mahan e a Geopolítica. Revista Marítima Brasileira, Rio de Janeiro, v. 130, n. 04/06, abr./jun. 2010, p.159.

O controle de Cuba, posicionada aproximadamente no centro deste Triângulo, seria primordial para os Estados Unidos controlarem o conjunto do Caribe. A ilha caribenha, do ponto de vista da posição geográfica, "não possuía rival militar entre as

aparecimento da obra The influence of sea power [...] Recorde-se que no início de 1903, foi assinado o Tratado Hay-Herran entre os Estados Unidos e a Colômbia, do qual o Panamá era parte. Mas, como o Senado colombiano não ratificou o Tratado, os Estados Unidos estimularam uma revolta panamenha contra a Colômbia - precedida por indicações de Roosevelt, que deu a entender que a marinha norte-americana apoiaria a "causa" da independência panamenha. Assim, o Panamá proclamou sua independência em 3 de Novembro de 1903. O USS Nashville, cumprindo a promessa de Roosevelt, em águas panamenhas, impediu qualquer reação colombiana. Estava aberto o caminho para a efetivação da proposta mahaniana, visando superar a vulnerabilidade diagnosticada. 
ilhas do mundo, com exceção da Irlanda”, advertia Mahan ${ }^{8}$. Afinal, a um só tempo, Cuba constituía na chave para o controle do Golfo do México, dominando as duas entradas neste golfo, ademais de controlar três entradas para o Caribe: o Canal de Yucatan, a Passagem Windward e a Passagem Mona (MAHAN, 1984, p. 36).

Assim, não é difícil compreender a centralidade que Cuba tem na visão estratégica norte-americana até os dias de hoje, dado ser o centro estratégico em sua área vital, perímetro de segurança ou primeira linha de defesa.

Com a abertura do Canal do Panamá, o controle do Caribe seria essencial, pois:

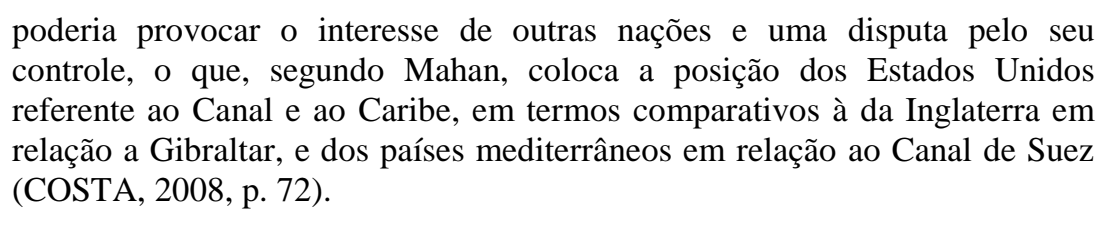

No caso brasileiro - objeto para o qual buscamos extrair lições destas análises -, podemos identificar, ao contrário do caso norte-americano ou francês, "a vantagem estratégica de uma posição central" (MAHAN, 1984. P.33), nomeadamente em relação ao Atlântico Sul e, muito especialmente, em relação ao chamado saliente nordestino, ponto de estrangulamento na passagem norte - sul e vice-versa.

\footnotetext{
${ }^{8}$ Em The interest of America in sea power, apud ALMEIDA (2010:163)
} 


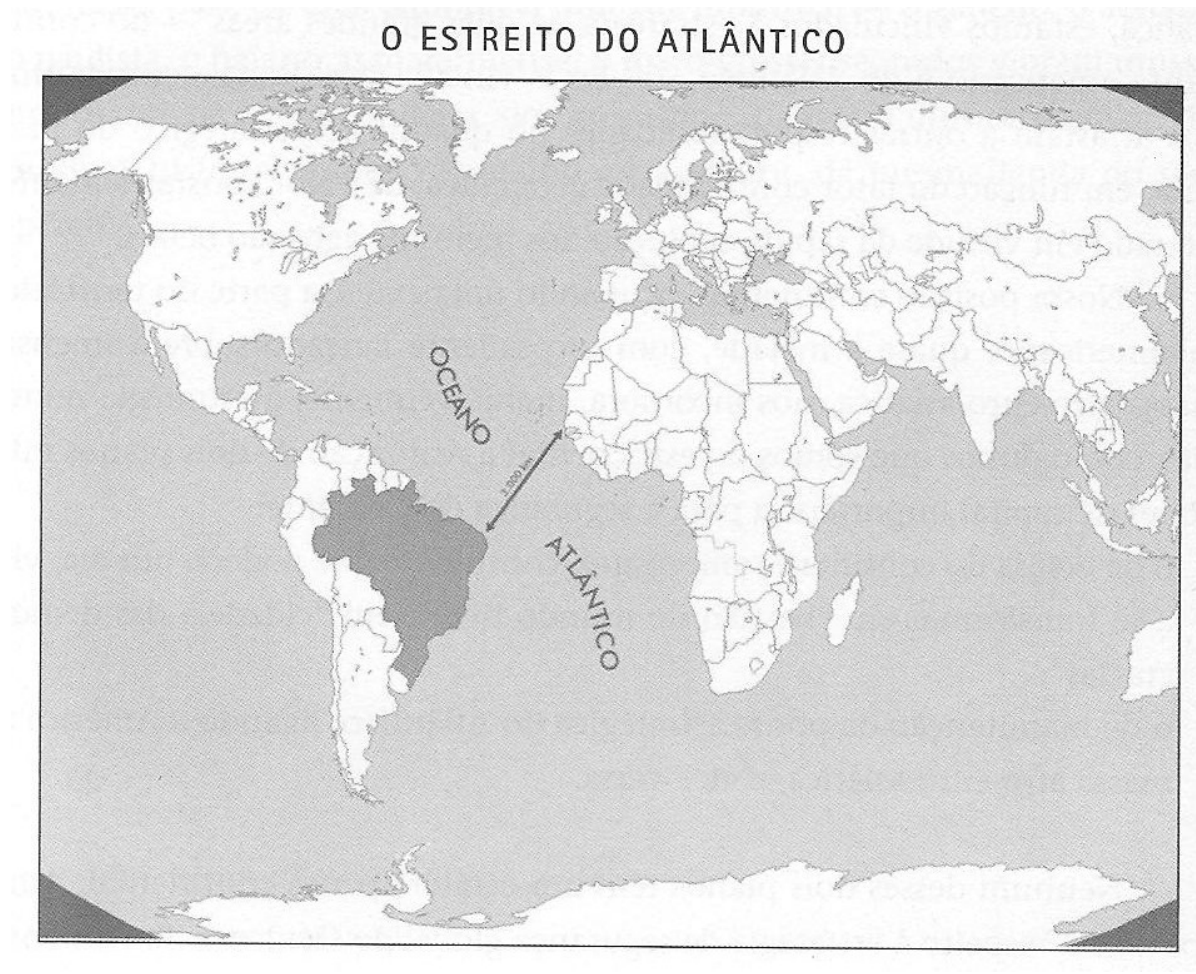

MAPA 03: MEIRA MATTOS (2011). Geopolítica. Rio de Janeiro: Editora FGV, 2011, p. 44

Esta permite vantagens estratégicas na eventualidade de ser necessária uma guerra de course com a destruição de rotas de comércio, por exemplo - ainda que um eventual bloqueio do Atlântico Sul, a partir do saliente nordestino, exigiria, pela largura e extensão, o uso, sobretudo, de meios submarinos para interromper o fluxo, seja comercial ou estratégico.

A vantagem da posição brasileira quanto ao Atlântico Sul é latente, dada nossa posição geográfica central. Afinal, para Mahan:
se a natureza colocou um país em circunstâncias tais que, além de ter acesso fácil ao alto-mar, fez com que ao mesmo tempo domine uma das grandes passagens do trafego mundial, é evidente que a importância estratégica de sua posição seja muito maior (MAHAN, 1984, p.37).

Voltemos ao caso de países sem a mesma condição estratégico-marítima. Para a superação da vulnerabilidade marítima, gerada pela posição geográfica, esclarece COSTA que: 
Mahan não vê outra saída para o país que não seja sua preparação militar, em suma, a transformação de seu potencial econômico, territorial e marítimo em poder estratégico. Bastará para isto, segundo ele, combinar corretamente suas vantagens: a maior disponibilidade de matérias-primas do globo, o tamanho e a posição de seu território e, com o novo Canal, a articulação entre o Pacífico, o Atlântico e o Caribe (COSTA, 2008).

Assim,

como estratégia básica, aconselha, o país deverá como medida preliminar, guarnecer suas costas, dedicando atenção especial aos portos e vias de penetração; num segundo passo, fixar postos avançados ou 'bases de operações' onde puder, em particular no Caribe (COSTA, 2008).

Desse modo, segundo Mahan:

com a entrada e a saída de embarcações do Mississipi protegidas; com postos avançados sobre controle, e com as comunicações com eles e a base de apoio seguras; em resumo, a preponderância militar adequada, para o qual o país possui todos os meios, a preponderância dos Estados Unidos nesta região, pela sua própria posição geográfica e seu poder, é uma certeza matemática (MAHAN, apud COSTA, 2008, p. 72).

Ainda no que diz respeito à centralidade da posição geográfica, para Mahan, esta "pode não só beneficiar a concentração de forças navais, mas também provocar uma grande vantagem estratégica ao possuir uma posição central em relação aos seus inimigos"9. Aqui ele percebia como favorável a posição inglesa. Por exemplo, nas três Guerras Anglo-Holandesas, "as linhas de comércio dos navios batavos passavam em frente a suas costas". Da mesma forma, "as principais linhas de comunicação mercante passavam necessariamente no norte da Europa, a um passo do poder naval inglês" (ALMEIDA, 2009, p. 144).

Há, assim, outras questões essenciais derivadas da posição geográfica de um dado país: primeiro, o problema das zonas de penetração, isto é, da Foz de rios que, se por um lado, facilitam o comércio em tempos de paz, por outro, revelam-se vulneráveis em tempos de guerra. Ao observar nossa desprotegida Foz do Amazonas vem à tona esta recomendação mahaniana - a despeito do colonizador português, visionariamente e precocemente ter percebido esta questão, erguendo fortes na foz do grande Rio. Hoje voltaremos ao tema adiante -, a constituição da $2^{\text {a }}$ Esquadra da Marinha do Brasil é base para a superação desta grave vulnerabilidade estratégica.

\footnotetext{
${ }^{9}$ ALMEIDA, 2009:143. Segundo Mahan, "esse conceito de 'posição central' foi baseado em Jomini, quando ele discutiu a importância para qualquer exército dispor de uma posição central em relação a dois inimigos simultâneos". A história segundo Alfred Thayer Mahan. Revista Marítima Brasileira, Rio de Janeiro, v. 129, n. 07/09, jul./set. $2009 \mathrm{~b}$.
} 
De acordo com Mahan:

O Mississipi é uma poderosa fonte de riqueza e de força para os Estados Unidos. Porém, as débeis fortificações em sua foz e os numerosos afluentes que penetram no país fizeram dele um fator de fraqueza e de desastres para a Confederação do Sul (MAHAN, 1984, p. 40).

A segunda questão refere-se à importância creditada por Mahan a posse de bases próximas ao teatro de operações. Aqui, a existência do cordão de ilhas britânicas constrangendo nossa projeção em relação ao Atlântico Sul (ver mapa p. 60) nos faz também observar a importância desta outra recomendação.

Por fim, aparece outra questão importante, de grande atualidade para os dias de hoje. Referimos-nos a ideia - que aparecerá novamente mais a frente - da importância atribuída por Mahan à posse de recursos naturais. Para ele, "não há nação superior aos EUA em todas as matérias primas que constituem a essência da força militar" (MAHAN, 1984, p. 36).

Assim, ele também considerava que a existência de recursos naturais poderia se converter numa vantagem ao país, desde que, além de bons portos, fosse acompanhado "de uma população que se projetasse no comércio marítimo como meio de expansão econômica". Caso contrário, argumentava,

\footnotetext{
a abundância de recursos naturais no território nacional poderia inclinar o povo lá residente a se contentar com as atividades agrícolas, sem a necessidade de procurar novos mercados e matérias-primas, obstando, dessa maneira, o desenvolvimento do poder marítimo (MAHAN, 1984, p. 45)
}

\section{O segundo fator do poder marítimo para Mahan é a conformação física do} país.

Mahan considerava o litoral de um país como uma de suas fronteiras - algo que depois, se consolidaria na teoria geopolítica como questão basilar. Para ele, quanto mais fácil fosse o acesso às linhas de comércio marítimo, mais propenso seria um povo manter comunicação com o restante do mundo. Por um lado, "portos numerosos e profundos são fonte de poder e riqueza", ainda mais "se estão na foz de rios navegáveis, (que) facilitam a convergência do comercio interior do país" (MAHAN, 1984, p. 37). Entretanto, no que é uma contradição em termos econômicos e estratégicos, "sua grande 
acessibilidade poderá se tornar em fator de fraqueza, em caso de guerra" (MAHAN, 1984, p. 37).

Como exemplo, Mahan apresentou o caso de uma esquadra batava, que em plena Guerra Anglo-Holandesa, em 1667, subiu o Rio Tâmisa "sem ser importunada", chegando a ameaçar a cidade de Londres; já a defesa deficiente da Boca do Rio Mississipi, por parte das forças confederadas, durante a guerra de Secessão norteamericana, permitiu o bloqueio desta região pela Marinha da União. É o exemplo que comentamos ao final da primeira questão sobre a fortaleza ou a vulnerabilidade de zonas de penetração aquíferas.

Para Mahan, a conformação física dependia, em grande medida, da prosperidade de uma nação. Contrapondo França à Inglaterra, lembrou que a primeira "tinha bom clima, uma produção agrícola relevante e excedente de bens", ao contrário da segunda, "que por possuírem um clima inclemente e uma produção agrícola tímida e ainda não terem passado pela revolução industrial" - referindo-se à época em que escrevia - "só tinham uma alternativa, o comércio marítimo, além da exploração de novas terras, mais agradáveis e produtivas que a própria Inglaterra”. Assim, em parte devido às próprias deficiências físicas, tornaram-se os ingleses "comerciantes, colonialistas e empreendedores" (MAHAN, 1984, p. 40).

Pior ainda era a situação holandesa. Segundo Mahan, "sem o mar, a Inglaterra emagrecia, enquanto que sem o mar a Holanda morre". Nesse sentido, o pensador em questão lembra que, segundo o cálculo de um importante escritor holandês, "o solo de sua pátria não poderia sustentar mais de um oitavo de sua população" (MAHAN, 1984, P. 40); esta alusão não poderia deixar de nos remeter, contemporaneamente, ao caso de países como a China e o Japão, impossibilitados de alimentar seu povo por meio de seu próprio território.

Voltando ao império holandês, lembra Mahan que em diversos momentos das guerras contra a Inglaterra, no século XVII, com a interrupção de seu comércio marítimo - aliás, de grande interesse dos ingleses, ávidos por tomar-lhe a posição -, a carestia atingiu fortemente os batavos.

Da mesma forma que a Espanha, a despeito de suas imensas possessões alémmar, viu-se inteiramente fragilizada, pois a despeito de "sua enorme dependência no 
comércio de metais", a ação dos corsários "não pode ser contestada no mar devido a sua flagrante fragilidade" do poder naval (MAHAN, 1984, p.45)

Em síntese, a configuração física do litoral, combinado com outros fatores pertinentes, como não negligenciar o mar, podem ser, para um país, fator essencial de expansão ou decadência. Por meio dos variados exemplos, Mahan demonstra "a debilidade de um país que depende exclusivamente de recursos externos, com relação ao papel que desempenha no mundo" (MAHAN, 1984, p. 46).

COSTA (2008, p. 73) nos recorda que Mahan "reconhece que a posição dos Estados Unidos encontra-se evidentemente inferiorizada em relação às demais potências marítimas". Afinal, os Estados Unidos possuem "apenas "potencialidades", mas "não possuem 'poder defensivo' que lhes permita fazer frente a qualquer ameaça”. Segundo Mahan, "sua maior fragilidade encontra-se justamente na relação 'não-orgânica' da população com o mar".

Nessa última questão - relação 'não-orgânica' da população com o mar -, o autor esboça um fator de emulação sociológica e cultural, relativa a importância de incentivar a maritimidade de um povo, cujo assunto será desenvolvido mais a frente

\section{Um terceiro critério - como os dois anteriores, igualmente de natureza geográfica -, é a extensão do território}

De acordo com Mahan, o fundamental não era a extensão total em milhas quadradas - que ademais poderia conformar-se em vantagem ou desvantagem -, "mas o cumprimento de sua linha costeira e o tipo de suas baías". Para ele, "a extensão de seu litoral pode ser um fator de força ou de fraqueza, conforme a população seja grande ou pequena".

Para um país, o essencial é possuir portos em quantidade e profundidade, além de protegidos. Também adquiria importância, "a capacidade de escoar bens, a partir do interior do país para esses portos". (MAHAN, 1984, p. 41). 
Nesta questão, relativa à extensão do território, Mahan volta a exemplificar a importância da proteção das vias de penetração do território, nos termos em que abordamos acima.

\section{Uma quarta condição mahaniana é o tamanho da população}

A partir daqui, ele passa a considerar elementos humanos para a consecução do poder naval. Este fator, diga-se de passagem, vincula-se exatamente ao elemento precedente, uma vez que ter um imenso território despovoado, converte-se para Mahan, numa desvantagem.

Entretanto, para medir o poder naval de um dado país - como, aliás, haveria de ser no sistema de pensamento de Mahan, dada a centralidade que tem para ele a questão do mar -, "o que interessava não era a população total existente no território, mas sim a parcela dessa população participante (ou pelo menos disponível) para as atividades marítimas" (MAHAN, 1984, p. 41)

Mahan apresenta o exemplo francês, após a Revolução de 1789. Não obstante, possuir uma população superior à britânica, em relação ao poder marítimo, a população naval (francesa) era infinitamente menor que a da Grã-Bretanha.

Mahan via na maritimidade da população (ou melhor, na falta dela), um fator de deficiência dos Estados Unidos. Lamentava que com a expansão para o Oeste, perderase muito da maritimidade. Para ele, a "única opção possível para seu país" - em termos de prosperidade - "era aumentar o comércio marítimo com bandeira norte-americana" (ALMEIDA, 2009, p. 146-147).

Nesse contexto, um debate importante proposto por Mahan, que terá, como veremos, consequências contemporâneas evidentes, é o papel de forças de reservas para Marinhas em igualdade de condições técnicas. Da maritimidade, da propensão ao mar, derivava a existência de forças de reserva que permitissem a sustentação da superioridade naval. Comparando as marinhas francesa e inglesa, afirma que "é tão duvidoso dizer qual é a mais poderosa". Assim, chama atenção para a importância para o fato de como são "úteis” as forças de reserva (MAHAN, 1984, P. 44). 


\section{Uma quinta questão essencial é o caráter nacional}

Para Mahan, "a tendência natural para o comércio era a característica nacional mais importante para o desenvolvimento do poder marítimo”. Aqui nesta questão, fica nítida a relação entre a influência protestante -, isto é, de uma suposta "ética do trabalho" - e liberal/mercantilista no pensador em questão. Nesse sentido, segundo Mahan, todos os homens buscavam obter riquezas, mas o modo como faziam isso era diferente, em função do caráter nacional.

Mahan se ampara no exemplo dos espanhóis do século XVI, os quais se projetaram internacionalmente como "o principal poder marítimo do período". No entanto,

\footnotetext{
essa qualidade de ousar e procurar novos caminhos transformou-se em avareza e, em virtude das facilidades obtidas nas novas terras conquistadas, [e] a busca por novos mercados transformou-se na coleta de metais preciosos - o ouro e a prata (MAHAN, 1984, p. 45)
}

Com essa postura, "desde a Batalha de Lepanto, em 1571, no Mediterrâneo, os espanhóis não obtiveram nenhuma grande vitória no mar" (MAHAN, 1984, p. 45). Assim, para Mahan, a deficiência do poder naval espanhol era reveladora de sua baixa "propulsão natural para enriquecer com o comércio marítimo", que caso fosse diferente, impulsionaria "a pressão sobre a coroa", a partir do próprio povo, para ações governamentais em direção ao mar.

Ele dá como exemplo o fato dos espanhóis que imigravam para as novas terras, que "não tiveram a preocupação em expandir o comércio com a terra-mãe". Com a "baixa produção espanhola, fizeram aumentar os infortúnios, diminuir a produção de manufaturas e a própria população".

Diante da decadência do poder marítimo espanhol e a dependência do comércio conduzido pelos holandeses, então sua colônia, aumentaram os rivais e adversários, tais como a Inglaterra e a própria Holanda, as chamadas "províncias unidas".

Mahan também teceu considerações a respeito do de Portugal, que ao ser absorvido pela União Ibérica, seguiu o mesmo caminho da decadência. Desse modo, 
As minas brasileiras foram fontes de riqueza de Portugal, assim como as do México e Perú o foram da Espanha; toda a indústria manufatureira caiu em um imenso descaso; por muito tempo os ingleses supriram os portugueses não só de roupas, mas também de toda a espécie de mercadorias, até mesmo de peixe salgado e cereais. Empolgados pelo ouro, os portugueses abandonaram seu próprio solo; as vinhas do Porto foram por fim compradas pelos ingleses com o ouro do Brasil, que havia tão somente transitado por Portugal para ser coletado para a Inglaterra (MAHAN, 1984, p. 46).

Assim, “em 50 anos, 500 milhões de dólares foram extraídos das minas do Brasil e apenas 25 milhões permaneceram em mãos portuguesas - um exemplo marcante entre riqueza real e fictícia” (MAHAN, 1984, P 46)

Aqui, por certo poderíamos recordar a situação venezuelana - cuja elite, há alguns poucos anos, até alface e agua mineral importava de Miami - ou do debate acerca dos riscos representados pela dádiva do pré-sal, no caso brasileiro.

\section{Como afirmou COSTA:}

administrando de modo despótico e predatório suas colônias, e dependendo da Holanda (para o comércio com a Europa) e da Alemanha (para o fornecimento de bens de todo tipo), Espanha e Portugal foram vítimas de seu próprio sistema e decaíram rapidamente 'a riqueza passou rapidamente por suas mãos', ou, como diz depois, 'não souberam distinguir a riqueza real da fictícia' (COSTA, 2008, p. 74).

Para ALMEIDA (2009, p. 148), Mahan louvava, por outro lado, o exemplo inglês e holandês, "povos marítimos por excelência", que, com "sabedoria e empreendimento", buscavam obter as riquezas "não apenas com a espada, mas também com o trabalho duro na curta e longa duração" (grifo nosso). Aqui, Mahan explicita sua visão norte-americana de raiz protestante, aliás, tão bem descrita por Max Webber em sua obra clássica A Ética protestante e o espírito do capitalismo.

Imbuído do espírito liberal anglo-saxão, Mahan também crítica a postura francesa, cuja nobreza, avalia, estava pouco propensa a ver o mar como fonte de riqueza, pois como "grandes responsáveis pelo financiamento dos empreendimentos comerciais, preferiram as honras nobiliárquicas e a sociedade de corte do que investir no comércio marítimo, fonte real de lucros e prosperidade”. (MAHAN, 1984, p. 48)

Para ele, haveria uma distinção entre ingleses, por um lado, e os ibéricos, por outro, referente ao "modo como as colônias eram percebidas". Para Mahan, "os colonos ingleses não apenas enviavam bens para a metrópole, mas preocupavam-se, 
fundamentalmente, com o desenvolvimento da própria colônia" (ALMEIDA, 2009, p. 149).

Aqui, é provável - sob pena de haver cometido um sério equívoco - que Mahan se referia à colonização de seu país; afinal não consta que as colônias inglesas no Caribe ou a então Guiana inglesa ao norte da América do Sul tenha tido sorte diferente dos países colonizados por Espanha e Portugal, no tocante ao desenvolvimento relativo. Em muitos casos, inclusive - vide o Cone Sul da América do Sul, Brasil incluído -, as colônias batavas e inglesas mostram, até hoje, nível de desenvolvimento inferior aos das ex-colônias portuguesa e espanhola.

Enfim, Mahan utiliza sua argumentação a respeito da ideia de caráter nacional, para defender que "seus compatriotas tinham a mesma índole comercial que os ingleses", ou que "os norte-americanos tinham o mesmo 'caráter nacional' dos ingleses" (ALMEIDA, 2009, p. 149).

Antes de iniciarmos a discussão da sexta questão, vale observar que Mahan, assim como Mackinder, como veremos, estava imbuído de uma visão profundamente etnocêntrica de mundo, em especial, por acreditar numa missão civilizatória do homem branco em relação aos chamados bárbaros. As guerras, aliás, em sua visão protestante, seria justificada moralmente por este caráter civilizatório da empreitada, de inspiração e, mesmo, "orientação" divina.

Por outro lado, não podemos negar que suas lições são consideradas até hoje atuais -, sobretudo em tempos de Marcha para o Leste ${ }^{10}$, derivada das riquezas do présal -, como a centralidade da manufatura, isto é, da indústria, na realização do desenvolvimento econômico.

Finalmente, a sexta condição é o caráter do governo

\footnotetext{
${ }^{10}$ Termo tomado do Embaixador Carlos Henrique Cardim, que em prefácio a PAIM (2011), ao recordar-se do livro de Cassiano Ricardo, precursor da geopolítica brasileira, denominado Marcha para o Oeste (1942), propôs que nosso, país, a partir das recentes descobertas petrolíferas no Atlântico Sul, poderia iniciar uma Marcha para o Leste.
} 
O que Mahan intitulou de caráter do governo, poderíamos denominar, mais apropriadamente, para a compreensão do sentido contemporâneo da ideia, de centralidade do interesse nacional.

Afinal, para os ingleses, a centralidade da questão naval se confundia com a própria perenidade do poder e da prosperidade nacional. Por isso, "os reis passavam, e as políticas navais permaneciam”. (MAHAN, 1984, p.54)

Nesse contexto, a primeira questão a destacar neste item é o fato do "governo" ou melhor, o Estado - corresponder ao "exercício do poder da vontade consciente" da nação, que "terá como efeito o sucesso ou o fracasso na vida de um homem ou na história de uma nação". Assim, Mahan pede "um governo em pleno acordo com as motivações naturais de seu povo" (MAHAN, 1984, p.50).

O pensador em questão dá exemplos de como a mentalidade marítima está assimilada à consciência social britânica. Nesse sentido, conta-nos o caso de um jovem capitão de navio, que ao iniciar a escolta de uma embarcação que conduzia o Duque de Sully à Londres, para audiência com o Rei Jaime I (1566-1625), ao ingressar em águas britânicas, ordenou aos visitantes arriar a bandeira francesa. Diante da recusa do francês, três tiros de advertência foram disparados e a ordem reiterada sob o argumento de que "a bandeira inglesa era a senhora dos mares".

Assim, a "atitude arrogante de um simples capitão de navio inglês", diante do distinguido convidado, simboliza que: "existia uma política naval (britânica) que era maior que aquele Rei Stuart", com quem o visitante se encontraria.

Mahan, por outro lado, dá como exemplo de "falta de visão governamental para os interesses marítimos", a postura francesa decorrente da saída de seu governo de Jean Baptiste Colbert - o principal incentivador do poder naval francês -, que fez, "para alívio da Inglaterra", com que Luís XIV (1638-1715) reorientasse a prioridade de seu país para as tropas terrestres e, assim, resultasse numa perda de poder marítimo francês e, consequentemente, a perda de poder na Europa.

\section{Como observa ALMEIDA:}

era uma questão de sobrevivência nacional a manutenção de um poder marítimo poderoso, como forma de proteger as colônias, impedir a travessia 
do Canal da Mancha para ataques contra o território inglês e defender suas linhas de comércio marítimo (ALMEIDA, 2009, p. 150-151).

Assim, como política de Estado, de "reis reconhecidamente 'ilegítimos' para o povo inglês, como, por exemplo, Carlos II, aliado de Luis XIV", até "um déspota esclarecido" como Cromwell, "a política nacional era voltada para a grandeza naval, segundo Mahan".

Passemos a outra questão importante do pensamento mahaniano, que aparece com intensidade no debate acerca do caráter de governo. Trata-se da defesa, por Mahan, do caráter ofensivo de uma armada.

Nesse sentido, ao criticar a decadência marítima francesa, Mahan alerta para:

um sistema que tinha como princípio que um Almirante não deveria usar a força que possuía, o que o colocava frente ao inimigo com o propósito preestabelecido de receber ataques em vez de fazê-los, um sistema que solapava o poder moral para poupar recursos materiais [...] (MAHAN, 1984, p.61)

Assim, o referido autor cita um oficial francês que afirmava o seguinte: "com frequência, nossos esquadrões deixavam o porto com uma missão especial a cumprir e com a intenção de evitar o inimigo; encontrá-lo era puro azar" (MAHAN, 1984, p.61).

Na crítica a estas atitudes - para ele, elemento essencial na decadência do poder naval francês -, percebe-se o quanto a ofensividade é aspecto central da visão mahaniana, que propõe essencialmente uma visão expedicionária do poder naval.

Em suas próprias palavras:

A palavra defesa envolve duas idéias (...). Há a defesa pura e simples que envolve a preparação a espera de um ataque. Pode-se chamá-la de defesa passiva. Por outro lado, há a defesa (...) melhor assegurada pelo ataque ao inimigo. O primeiro método é exemplifica pelas fortificações estacionárias, minas submarinas e geralmente, todos os elementos imóveis destinados simplesmente a parar o inimigo se ele tentar penetrar. O segundo método compreende todos os meios e armamentos com os quais não se espera pelo ataque, mas que encontram a frota inimiga, quer ela esteja a poucas milhas, quer em suas próprias águas. Tal defesa pode parecer uma guerra ofensiva, mas não é; ela torna-se ofensiva apenas quando seus objetivos de ataque são mudados de uma frota inimiga para um país inimigo (MAHAN, 1984, p. 67).

Mahan defende, ainda, que os Estados Unidos, mesmo geograficamente distante das grandes potências de então, deve tomar suas precauções em termos ofensivos numa clara demonstração de algo que perdura até os nossos dias -, confirmando o 
epíteto de "profeta do imperialismo" atribuído por Morison e Commager, ao qual nos referimos no início deste trabalho. Afirma Mahan, que:

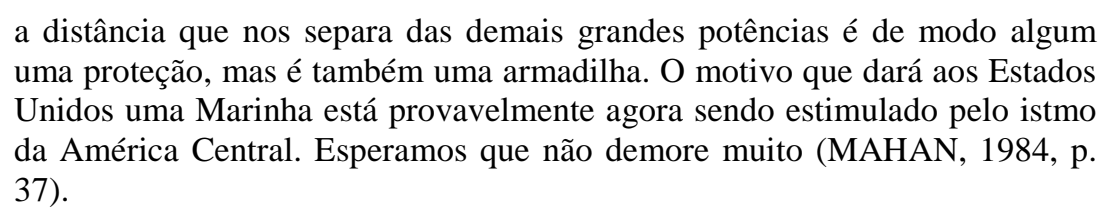

No debate sobre ofensividade versus passividade, o autor em questão observa algo relacionado à primeira questão (a posição geográfica), e que tem importância para o que discutimos neste momento. Segundo o autor em discussão, “com a extensa costa marítima dos Estados Unidos, um bloqueio (naval) completo não pode ser mantido efetivamente" dada à extensão do território a bloquear. Assim, a tática do inimigo seria "a tentativa de bloquear Boston, Nova Iorque, o Dalaware, o Chesapeake e o Mississipi, em outras palavras, os grandes centros de exportação e importação" (MAHAN, 1984, p. $66)$.

Transpondo para o caso brasileiro - que exploraremos novamente adiante -, é importante nos questionarmos: o inimigo não miraria o grande centro econômicoindustrial e populacional do país no caso de ataque ao país?

Mahan ressalta ser importante que "o inimigo seja mantido, não somente fora de nossos portos, mas também distante de nossas costas". Por acaso, o cordão de ilhas britânicas franqueadas à OTAN, que defrontam nosso litoral (ver mapa p. 60), não contraria essa regra estratégica básica? Quais medidas são necessárias para contrapor esta desvantagem estratégica? Vejamos isto no capitulo correspondente.

Ainda sobre o caráter ofensivo das orientações de Mahan, consideramos interessante a síntese proposta por Paul Kennedy, em Ascensão e queda das grandes potências, na qual propõe (KENNEDY, p. 100) um triângulo virtuoso em Mahan, o que podemos afirmar tratar-se do centro da formulação geopolítica do norte-americano. Este triângulo, julgamos, se constituiria da existência de Marinha Mercante, com grande capacidade para transportar bens, aliada a produção e fabricação de bens para a realização destas trocas; bem como da existência de colônias para a realização de troca comercial; e de bases navais para a expansão nacional.

Assim, concluindo, segundo ALMEIDA: 
disse Mahan que uma Marinha de Guerra era essencialmente uma força armada que tinha na mobilidade sua principal qualidade. Quanto mais afastados os interesses sujeitos ao ataque de um adversário, mais necessária se fazia uma Marinha de Guerra poderosa". Para isto, "era necessário aumentar a mobilidade da força e com isso, avultava a necessidade da aquisição de bases em diversas partes do mundo onde os 'interesses nacionais' se fizessem contrariados, de modo a permitir a ação ofensiva 'instantaneamente' (ALMEIDA, 2010, p. 170).

Quem estuda hoje a organização do poder naval norte-americano, com seus comandos regionalizados, que inclui a recente restauração da IV Esquadra no Atlântico Sul, ademais de uma extensa rede de base a eles fraqueadas em todo o mundo, não deixará de perceber que as orientações de Mahan, a despeito de terem aparecido ainda no final do século XIX, foram efetivamente postas em prática e perduram até os nossos dias, ao ingressarmos na segunda década do século XXI.

Por fim, outra questão, já mencionada, mas que aparece com grande importância no pensamento de Mahan, diz respeito à perenidade de suas observações, tendo em vista, como admite, que "as circunstâncias da guerra naval mudaram muito nos últimos cem anos [...]" (MAHAN, 1984, p.65). Por certo aqui, será necessário diferenciar questões de natureza conjuntural de questões perenes, relacionadas à orientação estratégica que guarda correspondência nas grandes batalhas, e das quais derivam grandes ensinamentos.

Com isso, concluímos, assim, as seis questões mahanianas voltadas para o estabelecimento do poder naval. 


\section{As teses principais de HALFORD JOHN MACKINDER}

Sir Halford John Mackinder nasceu em 15 de fevereiro de 1861, em Gainsborough, Inglaterra, e viveu até março de 1947. Foi um prestigiado professor de geografia, lecionando na Universidade de Londres, e membro do Parlamento britânico entre 1910 e 1922.

Mackinder é considerado um dos principais, senão o principal representante da geopolítica clássica, uma vez que desenvolveu sua expressão dominante, a do poder terrestre.

O pensamento de Mackinder é "alicerçado na ideia de que a geografia é o pivot (base, sustentáculo) da história". Trata-se de "uma teoria que tem na geoestratégia"1" isto é, segundo definição de Brzezinki, na gestão dos interesses geopolíticos -, "a chave para a hegemonia mundial" 12 .

Mackinder é tido como clássico da geopolítica, antes de mais nada, porque concebeu uma série de conceitos-chave para análise geopolítica que se mostram atuais, tais como o de heartland, área pivô, world island, anel insular ou exterior e anel interior ou marginal ${ }^{13}$. Alcançou esta condição de referência clássica escrevendo,

\footnotetext{
${ }^{11}$ VESENTINI define Geoestratégia como a dimensão espacial da estratégia. A estratégia, para este autor, é compreendida como uma redefinição da "arte da Guerra", isto é, onde uma tropa estaciona, para onde ela se desloca, etc. A geopolítica, por outro lado, teria como preocupação fundamental a correlação de forças no território, em especial, quanto ao espaço mundial. Ainda que, agrega o professor, "na prática, contudo, sempre foi extremamente difícil separar a geoestratégia da geopolítica" (Cf. VESENTINI, José William. Novas geopolíticas. São Paulo: Editora Contexto, 2008. p. 18). No Diccionario Latinoamericano de Seguridad y Geopolítica, no verbete Geoestratégia, o termo é definido como "conceito moderno da estratégia que amplia seus alcances, estendendo a proporções consideráveis do globo terrestre, como hemisfério e continentes" (Cf. BARRIOS, Miguel Angel. Diccionario latinoamericano de seguridad y geopolitica. Buenos Aires: Editorial Biblos, 2009). Já em MELLO, propõe-se utilizá-las "no sentido a elas atribuído por Zbigniew Brzezinski, sendo geopolítica"..."combinação de fatores geográficos e políticos que determinam a condição de um Estado ou região, enfatizando 0 impacto da geografia sobre a política", ao passo que a estratégia "refere-se à aplicação ampla e planejada de medidas para alcançar um objetivo basilar ou a recursos vitais de importância militar" (Cf. MELLO, Leonel Itaussu Almeida. Quem tem medo da geopolítica?. São Paulo: Editora Hucitec e EDUSP, 1999. p. 12). O próprio Zbigniew Brzezinski, no seu Gran tablero mundial (1998), ressalta que "a Geoestratégia é a gestão estratégica dos interesses geopolíticos" (Cf. BRZEZINSKI, Zbigniew. El gran tablero mundial: la supremacia estadunidense y sus imperativos geoestratégicos. Barcelona: Paidós, 1998).

${ }^{12}$ VESENTINI, José William. Novas geopolíticas. São Paulo: Editora Contexto, 2008.p. 18.

${ }^{13}$ Idem, Ibidem, loc. cit.
} 
essencialmente, dois textos curtos e um pequeno livro ao longo da primeira metade do século $\mathrm{XX}^{14}$.

O primeiro texto, com menos de vinte páginas, resulta de uma conferência "densa e concisa"15 pronunciada na Sociedade Geográfica Real de Londres, na virada dos séculos XIX para o XX, mais precisamente em 1904. Esta intervenção foi reproduzida no The Geographical Journal, com o título de The geographical pivot of history. Trata-se do texto inicial e basilar de Mackinder.

Em outro momento, estas ideias seriam desenvolvidas e atualizadas. Em 1919 já sendo observadas as consequências da primeira guerra mundial -, surge o livro Ideais democráticos e a realidade. Em 1943, já na condição de um autor consagrado, publica, a pedido da Foreign Affairs, um balanço de sua teoria, buscando novamente atualizá-la e desenvolvê-la, num texto denominado $O$ mundo redondo e a conquista da paz, de não mais que quinze páginas.

Nesta concisa apresentação, nos propomos a visitar as ideias essenciais contidas nos originais dos três materiais básicos que formam a teoria mackinderiana do poder terrestre.

A repercussão de The geographical pivot of history, decorre, antes de mais nada, de uma característica de Mackinder - que ademais, caracteriza a geopolítica em geral -, de propor formulações que representam consequências para a política de um Estado. Iniciativas políticas que, como diria Napoleão, revelam a geografia, isto é, o espaço e a posição de um Estado. Assim, das formulações de Mackinder, derivaram iniciativas que influenciaram o sistema internacional em todo o século $\mathrm{XX}$ e, podemos afirmar, certamente neste século XXI.

Afinal, como explicita COSTA, surgidas:

numa conjuntura marcada por disputas hegemônicas em escala mundial, as ideias de Mackinder, essencialmente pragmáticas e destinadas a 'formar opinião', acabaram por influenciar uma ampla área do pensamento

\footnotetext{
14 Nesta resenha crítica das teses básicas de Mackinder, utilizaremos como base e fonte primária estes três textos clássicos, e como fonte secundária, textos auxiliares indicados na bibliografia. Infelizmente, a despeito da relevância do autor, desconhecemos edição em português dos textos mencionados.

${ }^{15}$ MELLO, op. cit., p. 12.
} 
geopolítico, o que inclui até mesmo autores situados em campos opostos (COSTA, 2008, p. 77-78).

Como exemplo, cita geopolíticos que vão do alemão Karl Haushofer, por um lado, ao norte-americano $\mathrm{H}$. Weigert, por outro.

Assim,

o pragmatismo de Mackinder, por ele entendido como realismo, caracterizase por uma tentativa permanente de aliar a análise política de equilíbrio de poder do quadro internacional, os elementos empíricos (para ele concretos) fornecidos pelos estudos correntes fornecidos pela geografia. Dessa associação peculiar, entende o autor, surgiria a geopolítica (COSTA, 2008, p. 77-78).

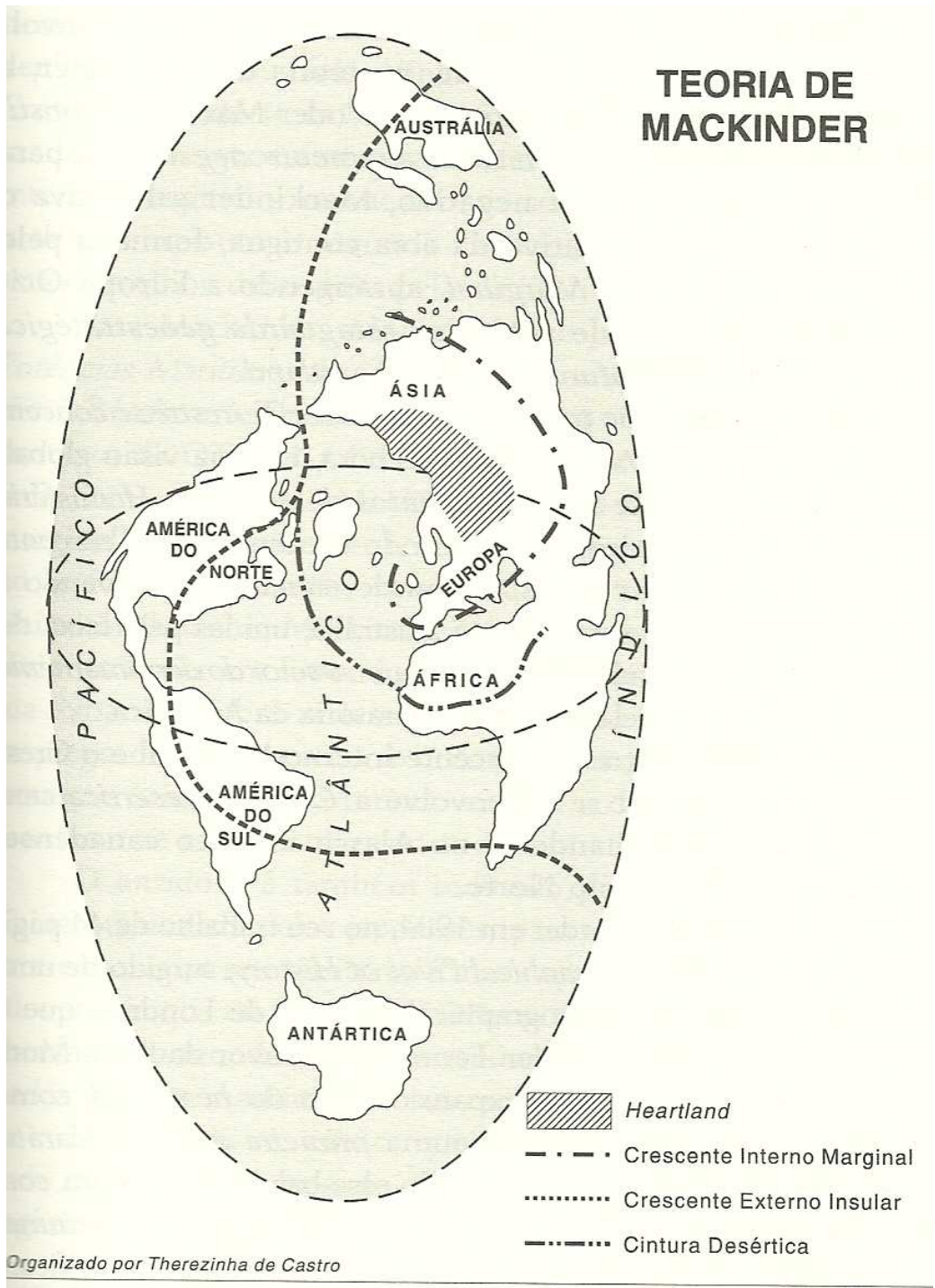

MAPA 04: CASTRO, Therezinha de. Geopolítica: princípios, meios e fins. Rio de Janeiro: Biblioteca do Exército Editora, 1999. 
Segundo MELLO (1999, p. 11), Mackinder apresenta, com o The geographical pivot, nesta ocasião, uma teoria que "tinha como idéia-chave a existência de uma rivalidade secular entre dois grandes poderes antagônicos que se confrontavam para a conquista da supremacia mundial: o poder terrestre e o poder naval". "O primeiro" sistematiza este autor - "sediava-se no coração da Eurásia e, mediante uma expansão centrífuga, procurava apoderar-se das regiões periféricas do Velho Mundo e obter saída para os mares abertos". Já o segundo, o poder naval, "situado nas ilhas adjacentes ou regiões marginais eurasianas" - os mencionados anéis - "controlava a linha circunferencial costeira do grande continente e, mediante uma pressão centrípeta, procurava manter o poder terrestre encurralado no interior da Eurásia”. Para este autor, "Mackinder realizou sua 'revolução copernicana', ao colocar em xeque a consagrada teoria do poder marítimo" (MELLO, 1999, p. 16).

Como observa COSTA (2008, p. 79), “a constituição deste espaço político mundial", em Mackinder, "afeta consideravelmente o comportamento externo dos Estados, já que, no seu entender, cada movimento, em qualquer parte do globo, repercutirá imediatamente no equilíbrio de forças", isto é, afeta a balança de poder ou a correlação de forças no sistema internacional.

Finalmente, como introdução, cabe destacar que de fato era significativo, que na Inglaterra insular, tendo em vista a tradição naval de seu país, que o geógrafo Mackinder, em sua obra de 1904, viesse a defender a ideia de "que a disputa pela hegemonia em escala global dependia da importância cada vez maior do que ele chamou de 'poder terrestre'" (COSTA, 2008)

Jones (apud COSTA, 2008, p. 86), por sua vez, considera, por um lado, “inteiramente lógico que os Estados Unidos tenham gerado a geopolítica de Mahan, país que necessitava superar seu "isolamento naval"”, ao passo que "a Inglaterra seguia a geopolítica de Mackinder, já que, hegemônica nos mares, impunha-se a necessidade de preocupar-se então com os hinterlands ${ }^{16}$ e, especialmente, com o heartland do globo".

\footnotetext{
${ }^{16}$ Segundo nosso Dicionário Latinoamericano de Seguridad y Geopolitica (Cf. BARRIOS, Miguel Angel. Diccionario latinoamericano de seguridad y geopolitica. Buenos Aires: Editorial Biblos, 2009. p. 227).
} 
O pivô geográfico começa afirmando ser possível considerar a exploração geográfica do globo terrestre "como quase terminada", tendo em vista que a era colombina "em 400 anos, completou o contorno do mapa", pelo que, "o início do século XX marca o fim de uma grande época histórica”. Assim, tendo em vista esta premissa, de que a partir do fim da "época colombiana" - a de Cristóvão Colombo -, o mundo estaria integrado em um "sistema político fechado" mais haveria áreas não descobertas pelo homem ocidental que não tivesse "dono".

Com isso, Mackinder se propõe a "buscar uma fórmula que expressará, até certo ponto, alguns aspectos da causalidade geográfica na história universal" ${ }^{\text {18 }}$.

Além de histórica- ainda que eurocêntrica e etnocêntrica -, não menos importante é perceber a visão de mundo mackinderiana profundamente condicionada pela territorialidade. $\mathrm{O}$ mesmo eurocentrismo se revela em Mackinder, ao aludir ao "desaparecido professor Freman", argumento que, em "certo sentido", é correta a ideia de que "a única história que tem importância é a das raças mediterrâneas e européias", pois, segundo Mackinder, "foi entre estas raças que se criaram as idéias que fizeram donos do mundo os herdeiros de Grécia e Roma".

Quem observa o papel pretérito da China, com o peso de sua milenar civilização, e ao ingressar nesta segunda década do século XXI, o papel que ela jogará no próximo período, perceberá que aqui, talvez, esteja o ponto mais flagrante de anacronismo em Mackinder.

Contudo, como sintetiza COSTA (2008, p. 79-80), Mackinder "dirige sua atenção preferencialmente para a imensa massa terrestre constituída pela Eurásia,

Hinterland "é um território ou área de influência. Especificamente, segundo a doutrina do hinterland, este conceito se aplica a uma região interna situada depois de um porto, onde se recolhem as exportações e através do qual se distribui as importações. A palavra provém do alemão e significa 'terra posterior' (a uma cidade, um porto etc.). Em um sentido mais amplo que o anterior, o termo se refere a uma esfera de influencia de um assentamento".

17 MELLO, Leonel Itaussu Almeida. Quem tem medo da geopolítica? São Paulo: Editora Hucitec e EDUSP, 1999. p. 213.

${ }^{18}$ MACKINDER, Halford J. El eje geográfico de la Historia. In: RATTENBACH, Augusto B. (Org.). Antologia Geopolítica. Buenos Aires: Editorial Pleamar, 1985. p. 65. 
fixando-se na ideia de que os povos e nações da Europa foram forjados em grande parte como reações sucessivas às ameaças externas provenientes da Ásia”. Nessa resistência coletiva, comum, está a base da formação das nações e das nacionalidades naquele continente, um dos berços da civilização humana.

Assim,

\begin{abstract}
relacionando as características climáticas e topográficas, com os movimentos de população e incursões dos povos dessa região em direção ao Ocidente, o autor conclui pela existência de um autêntico 'domínio terrestre', relativamente pouco povoado, mas dotado de características que permitiram aos seus povos (nômades em sua maioria) estender influência na Europa Ocidental às demais regiões asiáticas e até mesmo ao norte da África. COSTA (2008, p. 79-80)
\end{abstract}

Exemplo maior disto, certamente, foi Gengis Khan (1162 - 1227), conquistador e imperador mongol.

Mackinder propõe um importante conceito, ao defender que "as idéias que vão formar uma nação em oposição a um simples ajuntamento de animais humanos, geralmente tem se realizado sob a pressão de uma tributação comum ou diante da comum necessidade de opor resistência a uma força externa"19 (grifo nosso). Aqui, Mackinder apresenta uma ideia-força que é valida até os dias de hoje: a ocorrência de coesão e unidade nacional frente a um inimigo externo, que, em muitos casos, representaram a força que amalgamou nações e nacionalidades.

Assim, continua Mackinder, a "civilização européia é, num sentido muito real, produto da luta secular contra a invasão asiática", tese que, como veremos, será base de sua interpretação geopolítica a respeito da "terra-coração". Afinal, "o contraste mais notável que mostra o mapa político da Europa moderna” é a que "a vasta zona da Rússia ocupa a metade do continente e (por outro lado) os reduzidos territórios que ocupam as potências ocidentais".

Mackinder recorre novamente à história para afirmar que "os hunos, por ordens de Atila, se estabeleceram na parte central da Puzzta, no mais extremo das estepes danubianas, e a partir deste ponto, lançaram seus ataques contra o norte, leste e sul contra os povos estabelecidos na Europa". Assim, deduz o autor, que "é muito possível

${ }^{19}$ MACKINDER, Halford J. El eje geográfico de la Historia. In: RATTENBACH, Augusto B. (Org.). Antologia Geopolítica. Buenos Aires: Editorial Pleamar, 1985. p. 67. 
que os anglos e os saxões se viram então obrigados a cruzar o mar e fundar a Inglaterra nas ilhas britânicas"20.

Recorrendo a geografia, sustenta Mackinder que:

a massa terrestre da Eurásia assim compreendida entre o oceano e o deserto tem 21 milhões de milhas quadradas (54,4 milhões de quilômetros quadrados), ou seja, a metade da extensão das terras do globo, se excluímos do calculo dos desertos do Saara e da Arábia.

Reforçando sua visão da preponderância terrestre, prossegue Mackinder - a despeito da Eurásia "se caracterizar por uma notável distribuição de cursos d'água" -, estes são "praticamente inúteis para as comunicações humanas com o mundo exterior", isto é, com os oceanos.

Explica Mackinder que:

a concepção de Eurásia a que chegamos desta forma é a de uma terra continua, rodeada por gelos no norte e por água nas outras partes (...) com mais de três vezes a extensão da América do Norte e cujo centro e norte medem aproximadamente 9 milhões de milhas quadradas (23,3 milhões de quilômetros quadrados) ou seja, mais de duas vezes a extensão da Europa.

Não possuindo, desse modo, nenhum curso de água que chegue ao oceano "e com exceção da zona de bosques subárticos, são geralmente favoráveis a mobilidade dos homens que montam em cavalos ou camelos".

A seguir, explica o que mais tarde se consolidaria como um de seus conceitos chave, a ideia de anel marginal ou interior ao heartland. Segundo o referido pensador, "no leste, sul e oeste deste coração terrestre (Heartland, no original em inglês) ${ }^{21}$ estão as regiões marginais, na forma de amplos semicírculos que são acessíveis aos navegantes" (grifo nosso) ${ }^{22}$.

\footnotetext{
${ }^{20}$ Ibidem, p. 68-69.

${ }^{21}$ A única vez em que "heartland" aparece no Pivot geográfico da história.

${ }^{22}$ MACKINDER, Halford J. El eje geográfico de la Historia. In: RATTENBACH, Augusto B. (Org.). Antologia Geopolítica. Buenos Aires: Editorial Pleamar, 1985. p. 74-75.
} 


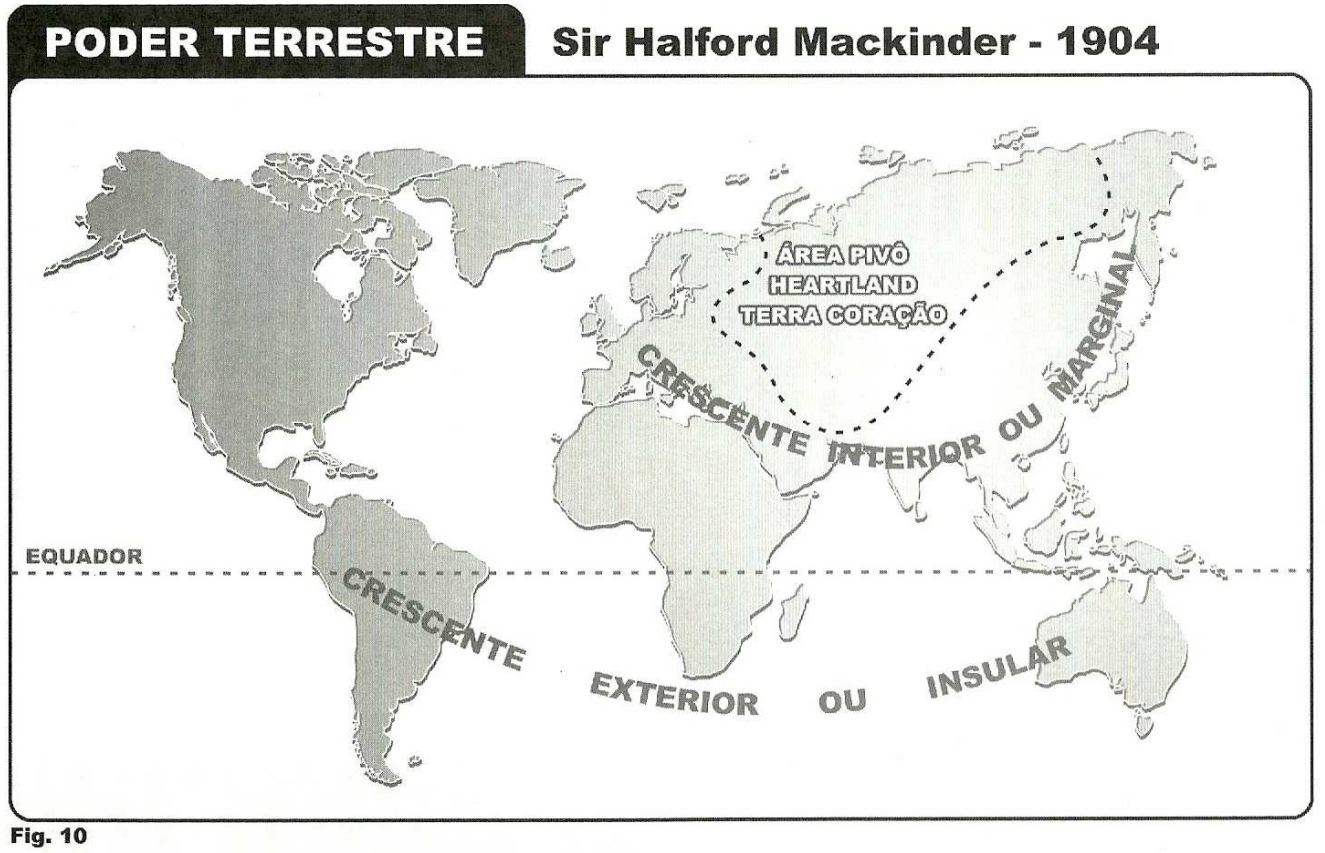

MAPA 05: (BONFIM, Uraci Castro. Geopolítica. Brasília: Escola de Comando e Estado-Maior do Exército, 2005.

Aqui está, pois, a essência da visão geográfica de Mackinder, com a descrição, por um lado, do Heartland - uma verdadeira fortaleza natural, não acessível pelos mares nem pelos rios - e por outro, das regiões marginais, dos anéis, estes sim, acessíveis por oceano.

O conceito ampliado de hertland, em lugar de algo mais estrito - área-pivot -, fica mais claro no trabalho Democratic ideals and reality, baseado na observação de que com a primeira guerra recém-findada, Mackinder resolve "alterar parcialmente seu esquema de balanço de poder estratégico" (COSTA, 2008, p. 86-87). O citado autor propõe, a respeito, uma excelente síntese da visão ajustada de Mackinder.

Afirma este autor que:

examinando o desfecho da guerra e a disputa permanente entre o sea-power e o land-power, conclui (Mackinder) que, dados os contornos dos cenários de guerra navais e terrestres, definiu-se um enorme conjunto supra continental constituído pela Europa, Ásia e África que ele chama de world island. Com isso, ele altera seu esquema de 1904, baseado na 'área pivô' (o 'coração continental'), com um entorno por ele chamado de marginal crescent (o resto 
da Eurásia) e insular crescent (América, África - ao sul do Saara -, Austrália e grandes ilhas européias). Desta feita, com a 'ilha mundial' surge um vasto conjunto transcontinental complementado perifericamente pelo southern heartland (África ao sul do Saara) e pelos 'satélites' (demais terras do insular crescent) (COSTA, 2008, p. 86-87).

"Finalmente", continua COSTA:

substitui a área pivot pelo heartland. Não se trata apenas de uma nova denominação para esse espaço estratégico. Ele altera também as suas fronteiras, adicionando ao antigo espaço o mar Báltico, o trecho navegável do baixo e médio Danúbio, o mar Negro, a Ásia menor, a Armênia, a Pérsia, o Tibete e a Mongólia. Este é o novo 'coração continental', espaço de poder estratégico que extrapola o território russo, já que na primeira guerra, até os mares e rios desta imensa região foram fechados às potencias marítimas (COSTA, 2008, p. 86-87).

Sobre a alteração - área pivô por heartland -, busquemos uma explicação com o próprio Mackinder em seu artigo de $1943^{23}$. Argumenta ele que "a palavra heartland aparece uma vez em um escrito de 1904, mas de modo acidental e como um termo descritivo e não técnico" (como conceito). Depois, continua:

ao término da primeira guerra mundial, no meu livro Democratic Ideals and Reality (...) claramente a etiqueta 'pivô', que havia sido apropriada para uma tese acadêmica no começo do século, não mais era adequada para uma situação internacional como a que emergia (MACKINDER, 1943).

Para melhor compreender estes conceitos, retornemos a The geographical pivot of history, no qual está implícita a valorização que Mackinder faz da imensa mobilidade na região eurasiana, chave para seu domínio terrestre.

Entretanto, Mackinder reconhece que:

o resultado mais destacado do descobrimento da rota que, passando pelo cabo da Boa Esperança, conduzia até a Índia, foi que uniu as navegações costeiras oriental e ocidental da Eurásia, ainda que por um caminho tortuoso, e em certa medida neutralizou as vantagens estratégicas da posição central que mantinham os nômades das estepes, pressionando sobre eles a partir de sua retaguarda.

Nesse sentido, continua o geógrafo inglês:

o Oceano, único e continuo que envolve as terras divididas e insulares é, por suposto, a condição geográfica fundamental de união para o domínio do mar e para todas as teorias de moderna estratégia e políticas navais, tal como expõem escritores como o capitão Mahan e o Sr. Spencer Wilkinson .

${ }^{23}$ Cf. MACKINDER, Halford J. El Mundo redondo y la conquista de la paz. In: WEIGERT, Hans W.; STEFANSSON, Vilhjalmur. (Org.). Política y poder em um Mundo mas Chico. Buenos Aires: Editorial Atlântida, 1948. p. 180. 
A citação de Mahan indica que Mackinder não apenas conhecia as teorias do norte-americano como, também, formula sua teoria em sintonia com a tese da supremacia dos mares, como observamos anteriormente.

Segue Mackinder chamando atenção para os grandes efeitos da passagem do Cabo da Boa Esperança para o continente europeu. Assim, as navegações colombianas provocaram um:

enorme efeito político, produzindo reflexos numa modificação radical das relações entre Europa e Ásia, porque na Idade Média, a Europa está entre um deserto que não se podia passar pelo sul, um oceano desconhecido pelo oeste, enormes zonas geladas ou cobertas de bosques pelo norte e noroeste e pelo leste e sudeste, as constantes ameaças da mobilidade superior dos nômades que montavam cavalos e camelos.

Foi o que permitiu, nos 400 anos que se seguiram, a colonização completa do globo terrestre. Desse modo, "criaram-se novas Europas em terras desocupadas descobertas no meio dos mares (...) constituindo um anel de bases exteriores e insulares para o poder marítimo, inacessíveis para o poder terrestre da Eurásia”. Com isso, Mackinder fornece excepcional explicação sobre o desenvolvimento do poder marítimo.

A despeito de reconhecer estes fatos objetivos, Mackinder, no entanto, pondera que "o poder terrestre todavia existe e recentes acontecimentos aumentaram seu significado".

Para ele,

enquanto os povos marítimos da Europa Ocidental têm coberto os oceanos com suas frotas, povoaram continentes exteriores e, em graus variáveis, converteram em tributários as bordas exteriores da Ásia (...) o poder russo se estende desde Moscou, através da Sibéria.

De acordo com o pensador em questão, pode-se afirmar que o contorno do Cabo da Boa Esperança é equivalente em termos estratégicos, bem como a mobilidade de cavaleiros no coração da Eurásia. Segundo Mackinder, "este ataque a oeste a partir da Ásia, levado a cabo por ginetes, foi um acontecimento quase tão fértil em consequências políticas como foi o contorno do Cabo da Boa Esperança".

A seguir, no que concerne à expressão da contradição que Mackinder enxerga entre maritimidade e continentalidade, sustenta o referido pensador que "a expansão da Europa por terra e por mar, continuou, num certo sentido, a antiga oposição entre os 
romanos e os gregos". Enquanto "os romanos-teutones se lançaram ao mar, os gregoseslavos cavalgaram pelas estepes conquistando os tarânios", diz Mackinder.

Mas para ele, a diferença essencial está na questão da mobilidade. Afirma, numa demonstração de seu decantado realismo, que "o moderno poder terrestre difere do marítimo não menos na fonte de ideais, mas nas condições materiais de sua mobilidade" ${ }^{24}$.

Noutro exemplo em que se apoia na questão da mobilidade para contrapor o poder terrestre ao poder marítimo, Mackinder argumenta que "com o (navio a) vapor e o Canal de Suez parecia haver aumentado a mobilidade do poder marítimo em relação ao poder terrestre" e "as ferrovias funcionavam principalmente como tributários do comércio oceânico". Mas, continua ele, “com as ferrovias transcontinentais agora estão se modificando as condições do poder terrestre e em nenhuma parte estes podem exercer tanto efeito como no fechado coração terrestre da Eurásia".

Desse modo, empolgado com as possibilidades de mobilidade no coração terrestre possibilitado pelas ferrovias, alega Mackinder que estas "tem um papel muito destacado nas estepes, porque podem substituir a mobilidade dos cavalos e camelos". Aqui, como se verá também nos outros dois trabalhos centrais, nota-se que, ao contrário do que diriam seus críticos, Mackinder percebe a importância das alterações tecnológicas no debate estratégico.

Em Democratic ideal [...], por exemplo, Mackinder acentua sua compreensão das novas possibilidades estratégicas advindas do progresso técnico-científico, lembrando que (apud Costa, 2008, p. 87) "hoje os Exércitos não dispõem apenas da Ferrovia Transcontinental, mas também de veículos motorizado. Possuem também aviões de poder terrestre contra o poder marítimo. [e] A moderna artilharia (...)".

Voltando a The geographical pivot [...], noutro trecho, de grande relevância contemporânea, Mackinder vincula as potencialidades naturais à potencialidades econômicas. Segundo o pensador, no Império Russo e na Mongólia, "são até certo ponto incalculável suas potencialidades enquanto a população, produtora de trigo,

${ }^{24}$ MACKINDER, Halford J. El eje geográfico de la Historia. In: RATTENBACH, Augusto B. (Org.). Antologia Geopolítica. Buenos Aires: Editorial Pleamar, 1985. p. 76-77. 
algodão, combustíveis e metais, sendo inevitável que lá se desenvolva um grande mundo econômico, mais ou menos isolado, que será inacessível ao comércio oceânico". Ao lado da valorização do território, Mackinder valoriza enormemente a possibilidade de países ricos em recursos naturais tirarem vantagem estratégica dessa condição, estabelecendo modelos autárquicos que permitam a sustentação de seu poder.

Mackinder conclui seu célebre The geographical pivot of history questionando "se não é evidente uma certa persistência da relação geográfica" em relação ao curso histórico. Ou se "não é a região pivô da política mundial essa extensa zona da Eurásia, que é inacessível aos tanques, mas que antigamente estava aberta aos ginetes nômades e hoje estão ao ponto de ser cobertas por uma rede de ferrovias?", pergunta.

Assim, diz ele, nesta zona eurasiática há, a um só tempo, uma mobilidade transcendente e ao mesmo tempo limitada do poder terrestre. Aqui aparece a relação entre poder centrífugo e poder centrípeto que propusemos anteriormente.

Desse modo, de acordo com Mackinder, a Rússia ocupa um lugar no mundo similar ao que a Alemanha ocupa no centro da Europa. Para ele, "não possuir nada no mar é para a política russa uma lei tão fundamental como para a Inglaterra possuir o domínio dos oceanos".

Afirma o pensador em questão que, dada estas características especiais da Rússia, como estado pivô, sua condição, digamos, geopolítica e geoestratégica "não é equivalente aos periféricos", isto é, "fora da zona pivô, num grande arco interior, estão a Alemanha, Áustria, Turquia, Índia e China e num arco exterior, Inglaterra, África do Sul, Austrália, Estados Unidos, Canadá e Japão”.

Revelando seu temor como inglês, Mackinder adverte para o risco de o mundo ser dominado por uma aliança russo-germânica. Para ele,

\footnotetext{
o equilíbrio se tombaria a favor do Estado pivô, como resultado de sua expansão para as terras marginais da Eurásia, permitindo a utilização de amplos recursos continentais para construção de uma frota e (assim), o império do mundo estaria a vista. Isso poderia ocorrer se a Alemanha aliar-se a Rússia.
}

Para desespero de Churchill e dos ingleses, isso se gestou taticamente em 1943, quando funcional a ambos lados, alemães e soviéticos assinam pacto de não-agressão, que a despeito de seus efeitos, rapidamente seria desfeito. . 
Em Domocratic ideals [...], de 1919, fruto da guerra recém-findada, Mackinder volta a manifestar preocupação com a ameaça alemã de domínio da Europa do leste, com risco de a "força estratégica alemã, que poderia tornar-se o núcleo de poder do heartland". Neste trabalho, reiterando sua preocupação com uma possível aliança Alemanha-URSS, surge seu mais famoso alerta: “Quem domina a Europa Oriental, comanda o Heartland. Quem domina o Heartland, comanda o world-island. Quem domina o World-island, comando o mundo",25.

A seguir, retornando a The geographical pivot [...], visionariamente - tendo em vista a presente época -, Mackinder adverte que "o desenvolvimento das grandes potencialidades da América do Sul podem ter influência decisiva no sistema". Entretanto, com olhar da virada do século XIX para o XX - e não certamente no período atual -, sustenta que a América do Sul "pode fortalecer os Estados Unidos, ou pelo contrário, a Alemanha, se esta puder desafiar com êxito a Doutrina Monroe".

Noutro trecho, discute a diferença de agilidade entre o grande Estado localizado no coração da Eurásia e os Estados que o circundam. Para ele,

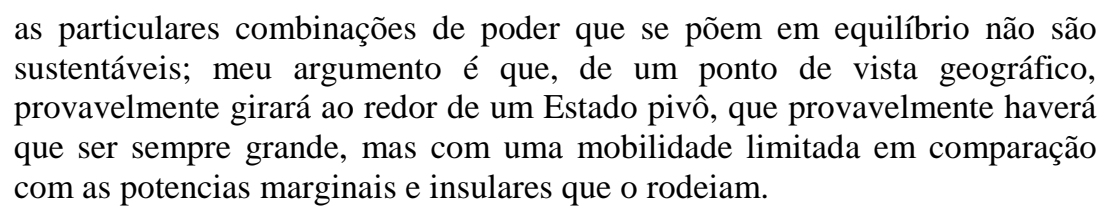

Estaria ele se referindo ao poder de atração dos grandes Estados em relação aos que os circundam?

Na última frase do Pivot geográfico, igualmente visionária é a questão da emergência da China, dado da realidade atual. O pensador pede atenção ao "perigo amarelo para a liberdade do mundo" representado pela possibilidade de "os chineses, organizados pelos japoneses, [chegarem] a vencer o império russo e conquistarem seus territórios". Afinal, "simplesmente porque agregaria uma frente oceânica aos recursos do grande continente, vantagens que os russos, ocupantes da região pivô, todavia não puderam gozar" 26 .

\footnotetext{
${ }^{25}$ MACKINDER, Halford J. Democratic ideals and reality. New York: Henry Holt and Company, 1942. p. 150. (tradução nossa).

${ }^{26}$ MACKINDER, Halford J. El eje geográfico de la Historia. In: RATTENBACH, Augusto B. (Org.). Antologia Geopolítica. Buenos Aires: Editorial Pleamar, 1985. p. 78-81.
} 
A movimentação chinesa atual, em aliança com os russos, na Organização de Cooperação de Xangai, de natureza estratégica e econômica, visando polarizar os Estados da Ásia Central - especialmente os pertencentes à ex-União Soviética -, dá inteira razão à advertência de Mackinder.

Segundo COSTA (2008, p. 82-83), “a leitura do paper por Mackinder naquele 25 de janeiro de 1904 na Real Sociedade Geográfica gerou as mais variadas reações", inclusive houve quem lamentasse a ausência de membros do Gabinete, dada a óbvia relação dos temas tratados com o interesse nacional inglês. Há quem contestou as teses de aumento do poder terrestre, dado o "enorme aumento na capacidade das embarcações militares no transporte de tropas, aliada a sua maior mobilidade propiciada pela propulsão a vapor”. Mackinder contra-argumentou que:

\begin{abstract}
o conceito de mobilidade num futuro próximo não estaria num ou noutro domínio de circulação (mar ou ferrovia, por exemplo), mas na articulação de ambos, podendo contar ainda, brevemente, com a navegação aérea como força complementar. Nesse sentido, conclui, o poder político e militar só pode ser perseguido quando a potência puder contar com uma solida base técnico-científica e industrial, o que certamente diminui a importância relativa de sua posição geográfica (MACKINDER, apud COSTA,).
\end{abstract}

A posição estratégica sem igual dos Estados Unidos, após a segunda guerra, até os dias atuais, dá inteira razão ao geógrafo inglês.

Quinze anos depois de sua magistral conferência e coincidindo com o término da primeira guerra, observa COSTA (2008, p. 83) que Mackinder "retoma em um livro as suas idéias básicas sobre o 'coração continental', modificando-as em alguns de seus aspectos e aprofundando as principais teses apresentadas em 1904". Trata-se de Democratic ideals and reality, de fevereiro de 1919, um pequeno livro de pouco mais de duzentas páginas.

Boa parte do livro é dedicada à visão de mundo, digamos, filosófica, de Mackinder, com longas digressões sobre "o idealismo democrático". Há também dois capítulos dedicados a "liberdade" (freedom), uma dos homens, outra das nações. No trabalho, como lembra COSTA, "sua antiga tese de que era necessário aliar democracia com realismo político é destacada e desenvolvida". 
Para efeito deste trabalho, interessa, sobretudo, sua busca de contrapor em dois capítulos distintos, the seaman's point of view ao the landsman's point of view. Para COSTA (2008), uma clara tentativa de polemizar com Alfred Mahan.

Entretanto, para Jones (apud COSTA, 2008), ele "evita a simplificação de uma oposição frontal entre o 'poder marítimo' (Mahan) e o 'poder terrestre' (Mackinder)”. Para este autor, Mahan estava atento para o poder estratégico representado pela Rússia, mas, ao contrário de Mackinder, "acreditava que essa expansão poderia ser freada por uma política de contenção das demais potências baseadas no poder marítimo”.

A ideia da contenção, tanto marítima quanto terrestre, nas bordas da Eurásia, seria mais a frente desenvolvida por Nicholas John Spykman, com sua teoria das "fímbrias" (ou Rimland) - que basicamente propunha ocupar as bordas do world island -, seguida por George Kennan, que em 1946 escreveria aquele que ficou conhecido como The long telegram - uma proposta de contenção da União Soviética, adotada pelos EUA como Doutrina Truman, em alusão ao então presidente estadunidense, Harry S. Trumam - conforme pode ser visto no capitulo III.

Um importante desenvolvimento das teses de Mackinder, diz respeito, como observa COSTA que:

\begin{abstract}
apesar dos oceanos constituírem um único e vasto espaço de circulação (na verdade, para ele, existia um único oceano), a história demonstrava que os gregos, romanos, povos cristãos, etc., sempre se relacionavam com porções regionais dos mares e oceanos, capturando com sua circulação e domínio espaços mais ou menos restritos deste 'oceano' (COSTA, 2008, p. 86).
\end{abstract}

Em outras palavras, buscava-se uma nacionalização do oceano frontal, tanto em termos de rotas econômicas como estratégicas - algo que hoje é regulamentado internacionalmente pela Convenção das Nações Unidas sobre o Direito do Mar.

Finalmente, em julho de 1943, aparece na Foreign Affairs, seu $O$ mundo redondo e a conquista da paz, tendo em vista, diz ele, pedidos para "considerar se meu 
conceito estratégico de 'Heartland' perdeu alguma significação diante das novas condições de guerra" (Mackinder, 1948, p. 178).

O autor, retornando às suas comparações acerca de poder terrestre - poder naval, e novamente recorrendo ao transcendental contorno do sul da África, começa traçando um paralelo entre "Vasco da Gama, dando a volta no Cabo de Boa Esperança em sua viagem a Índia, até os finais do século $\mathrm{XV}$, e a arremetida a cavalo de Yermak, o cosaco, a frente de seus ginetes através dos Montes Urais até a Sibéria, no começo do século XVI". A seguir, reafirma com mais clareza, ainda, sua tese a respeito das pressões centrifugas vindas do heartland contra os povos estabelecidos nos Himlands. Desse modo, afirma o autor:

esta comparação por sua vez me induz a revisar uma longa sucessão de incursões levadas a cabo pelas tribos nômades da Ásia ao longo da antiguidade clássica e da Idade Média contra a população estabelecida nas bordas dos subcontinentes: Europa peninsular, Oriente Médio, Índia e China.

Mackinder esclarece que "o Heartland é a parte norte e interior da Eurásia". Ainda, assim, adverte, "o conceito não admite uma definição precisa sobre o mapa, pela simples razão de estar baseado em três aspectos separados da geografia física que, enquanto se reforçam mutuamente, não coincidem uns com os outros". Contudo, adverte que "não obstante estas aparentes discrepâncias, o heartland oferece uma base física suficiente para o pensamento estratégico" ${ }^{27}$. Aqui, por base física suficiente para o pensamento estratégico, tendo em vista o já apresentando, argumenta-se sobre a importância de recursos naturais abundantes para obter ampla capacidade de retaguarda estratégica.

Reconhecendo que "é suficientemente exato dizer que o território da URSS é equivalente ao heartland, exceto em uma direção" e, como dissemos, em algo muito relevante em termos de manobra estratégica, que "a sua retaguarda (da então URSS) encontra-se a vasta planície do heartland, apta para a defesa em profundidade e para a retirada estratégica". Talvez Mackinder já tivesse em mente, ao dizer isso, a retirada estratégica soviética de tropas e suprimentos (incluindo fábricas que foram desmontadas

${ }^{27}$ Cf. MACKINDER, Halford J. El Mundo redondo y la conquista de la paz. In: WEIGERT, Hans W.; STEFANSSON, Vilhjalmur. (Org.). Política y poder em um Mundo mas Chico. Buenos Aires: Editorial Atlântida, 1948. p. 179-181. Sobre a referência à China, não se pode deixar de mencionar a grandiosa Muralha desse país, com seus mais de três mil quilômetros, com a sua função de conter as constantes invasões dos povos ao Norte, e concluída exatamente no século XV, durante a Dinastia Ming. 
e remontadas no interior) ordenada por Stalin e tida por muitos como essencial para a posterior reação e vitória ao avanço nazista sob o território russo.

Discutindo a atualidade do conceito do heartland, Makinder lembra que "é certo que a costa ártica já não é inacessível no sentido absoluto que a palavra tinha a alguns anos", tendo em vista os quebra-gelos e as aeronaves de reconhecimento desenvolvidas, "mas uma invasão de forças hostis através de uma vasta extensão de gelos circumpolares e sobre os musgos da tundra e dos bosques da taiga do norte da Sibéria parece quase impossível frente às defesas aéreas soviéticas baseadas em terra”. Hoje, quando observamos uma nova disputa do polo norte pelos que defrontam este território - Rússia, Dinamarca (metrópole da Groenlândia), Canadá, EUA e Noruega, que já pleitearam a posse da região, e sempre tiveram negado tais pedidos pela ONU, percebemos o quanto esta região possui de potencial estratégico e econômico.

Escrito em meio ao desenrolar da segunda guerra, Mackinder vê o rompimento por Hitler do chamado Tratado Molotov-Ribbentrop, exatamente porque "a agricultura mais próspera e suas indústrias (soviéticas) se encontravam no caminho do invasor".

Como dissemos acima, Mackinder, para defender a atualidade de seu conceito, volta a referir-se às "vastas potencialidades" do heartland. Para ele, exceto por uma então deliberada política soviética, de apresentar "umas poucas mercadorias, o país pode produzir tudo o que necessita".

Nesse sentido, previa Mackinder, em pleno ano de 1943, que "se a União Soviética emerge desta guerra como conquistadora da Alemanha, deve ser classificada como a primeira potência do globo. Será ademais a potência colocada estrategicamente na posição mais vantajosa do ponto de vista defensivo". Afinal, conclui, "o heartland é a maior fortaleza natural do planeta", chamando atenção para o fato de o heartland ser "a fortaleza do poder terrestre no grande continente do mundo". Quem observar o desenrolar da guerra fria dará razão ao geógrafo inglês.

Diante da ameaça soviética, o pensador pede "que haja uma efetiva e duradoura cooperação entre a América do Norte, Inglaterra e França”, e, ainda, que os três países, mais a Rússia, se comprometam "com que o diabo não possa jamais levantar a cabeça na Alemanha e morra de inanição". 
Mackinder também se dedica a polemizar com a tese de que o poder aéreo poderia liquidar "tanto frotas (navais) como exércitos", citando, para tal, "um combatente aéreo" que dizia o seguinte: "o poderio aéreo depende absolutamente da eficiência de suas organizações em terra". Ou seja, não há autonomia absoluta - apenas relativa - do poder aéreo.

Concluindo seu raciocínio, Mackinder chega a sustentar, no que se refere ao conceito do heartland, que "não [duvidava] em afirmar que é mais válido e mais útil hoje do que era há vinte ou quarenta anos atrás". Afinal, lembra o autor, observando o desenrolar da segunda guerra mundial, "pela primeira vez na história, há dentro desta vasta fortaleza natural uma guarnição adequada para negar a entrada ao invasor germânico". Assim, como viria a verificar-se, dado que:

\begin{abstract}
a largura da entrada na fortaleza constitui uma vantagem, pois brinda a oportunidade de derrotar o inimigo obrigando-o a realizar um amplo deslocamento de seu poderio humano. E em cima e em baixo do heartland, há um amplo depósito de rico solo para a obtenção de colheita, minerais e combustíveis, equivalente - ou quase equivalente - a tudo o que está acima ou abaixo dos Estados Unidos e domínio do Canadá (MACKINDER, 1948, p. 184-188).
\end{abstract}

A exemplo de outros textos, Mackinder conclui seu trabalho com uma visão profética, ao retomar, novamente, a importância da posse de recursos naturais. Lembra que "as florestas tropicais de ambos os lados do Atlântico sul, a das Américas e as da África (...) poderiam sustentar a um bilhão de pessoas". É o que provavelmente veremos neste século XXI. 


\section{CAPÍtUlo II}

\section{Atualidade e superações, pontos de contato e diferenças em Mahan e Mackinder}

Neste segundo capítulo, buscaremos apresentar pontos de identidade e de diferenças entre Mahan e Mackinder, seguido de debate sobre a atualidade e as superações em ambos os autores.

$* * *$

Parafraseando a famosa frase da Marx, ao estudarmos as teses centrais de Mahan e Mackinder, podemos dizer que seus espectros continuam rondando o mundo. Para além de algumas opiniões superadas ou anacrônicas - natural em autores que escreveram no final do século XIX e início do $\mathrm{XX}$-, nas teses centrais dos dois autores, encontramos ensinamentos perenes, que justificam sua condição de clássicos fundadores da geopolítica.

A principal potência hegemônica de nossa época, os Estados Unidos, utilizaram, e utilizam até hoje, em larga escala, os preceitos centrais dos dois autores.

Podemos exemplificar, antes de mais nada, pela colossal superioridade norteamericana no mar - com uma Marinha que é dividida em comando que abarca toda a esfera terrestre, e, mais do que isso, controlam de facto os principais pontos de passagem (rotas de comércio), como o Canal do Panamá, o de Gibraltar, o de Suez, o estreito de Malaca, etc.

Aludindo a isto, afirma Brzezinski:

\footnotetext{
se construíram impérios através da cuidadosa conquista e manutenção de posições geográficas vitais, tais como Gibraltar, o canal de Suez ou Singapura, que serviram como ponto de estrangulamento ou eixos de uma sistema de controle imperial (BRZEZINSKI, 1998, p. 45).
}

Podemos, também, argumentar a respeito da imensa centralidade estratégica que os Estados Unidos, mesmo com o fim da guerra fria, continuam dedicando à vasta massa terrestre da Eurásia, chamada por Mackinder de ilha-mundial. Por exemplo, na 
Ásia Central, ponto cardeal para a manutenção da hegemonia na Eurásia. Bastaria dizer, aqui, da enorme presença militar norte-americana no Afeganistão ou das investidas de Barack Obama em relação à Índia e a Rússia para justificar a permanência de uma opção mackinderiana por parte da superpotência.

Hoje, diante de um mundo marcado por uma transição de época, de incertezas e tendência a intensificação de conflitos de variadas naturezas, e de crescente instabilidade - como veremos mais detidamente no capitulo III -, torna-se essencial retornar aos clássicos do pensamento geopolítico, buscando extrair lições que possam servir à época atual e identificando seus anacronismos. De forma introdutória, é o que buscamos nestes dois primeiros capítulos.

O sentido da ida aos clássicos da teoria geopolítica visa, nesta Dissertação, fornecer uma base para a discussão de uma "grande estratégia" contemporânea no pensamento geopolítico brasileiro.

Assim, neste capítulo, tratamos de identificar elementos de "permanências e descontinuidades", primeiro em Mahan, depois em Mackinder. Em seguida, apresentamos pontos de contato e oposições entre os dois autores. Em todos os casos, buscamos sempre que possível extrair lições e relacionar as questões com os debates contemporâneo das relações internacionais e, em especial, com a situação brasileira e sul-americana.

\section{Algumas permanências e descontinuidades em MAHAN}

O principal fator de permanência em Mahan é o fato de suas teses sobre a primazia do poder naval, escritas no final do século XIX, e tendo passado, portanto, mais de um século de seu aparecimento, seguirem influenciando as atitudes das principais Armadas no mundo. Em especial, a de seu país, de longe, a principal força naval nos séculos XX e neste início do XXI.

Como lembra o Almirante Accioly Fragelli, comandante do programa de submarinos da Marinha do Brasil (JOBIM, 2010, p. 498-503), atendendo a ensinamento mahaniano, "a Marinha norte-americana possui uma capacidade de se deslocar e operar em qualquer teatro do mundo com grande rapidez e eficiência". Além disso, apresenta 
“comandos específicos para cada área geográfica de acordo com a estratégia militar" do país.

Contam os Estados Unidos com extensa rede de bases navais literalmente em todos os Oceanos; por exemplo, defrontando o litoral brasileiro e sul-americano está um cordão de bases navais, resquício de outrora, um vasto império britânico, que estão fraqueadas à utilização dos países da OTAN. Trata-se de pequenas ilhas que seguem colônias daquele país, tais como a ilha de Ascensão, Santa Helena, Tristão da Cunha, Gough, Geórgia do Sul, Sandwich do Sul, Orcadas do Sul e as ilhas argentinas das Malvinas, ocupadas pela Inglaterra (ver mapa a seguir). Estas ilhas representam, parafraseando o que disse o general norte-americano Douglas Mac Arthur a respeito de Taiwan, "um porta-aviões incapaz de ser afundado".

\section{O Atlântico Sul e as bases britânicas da OTAN}

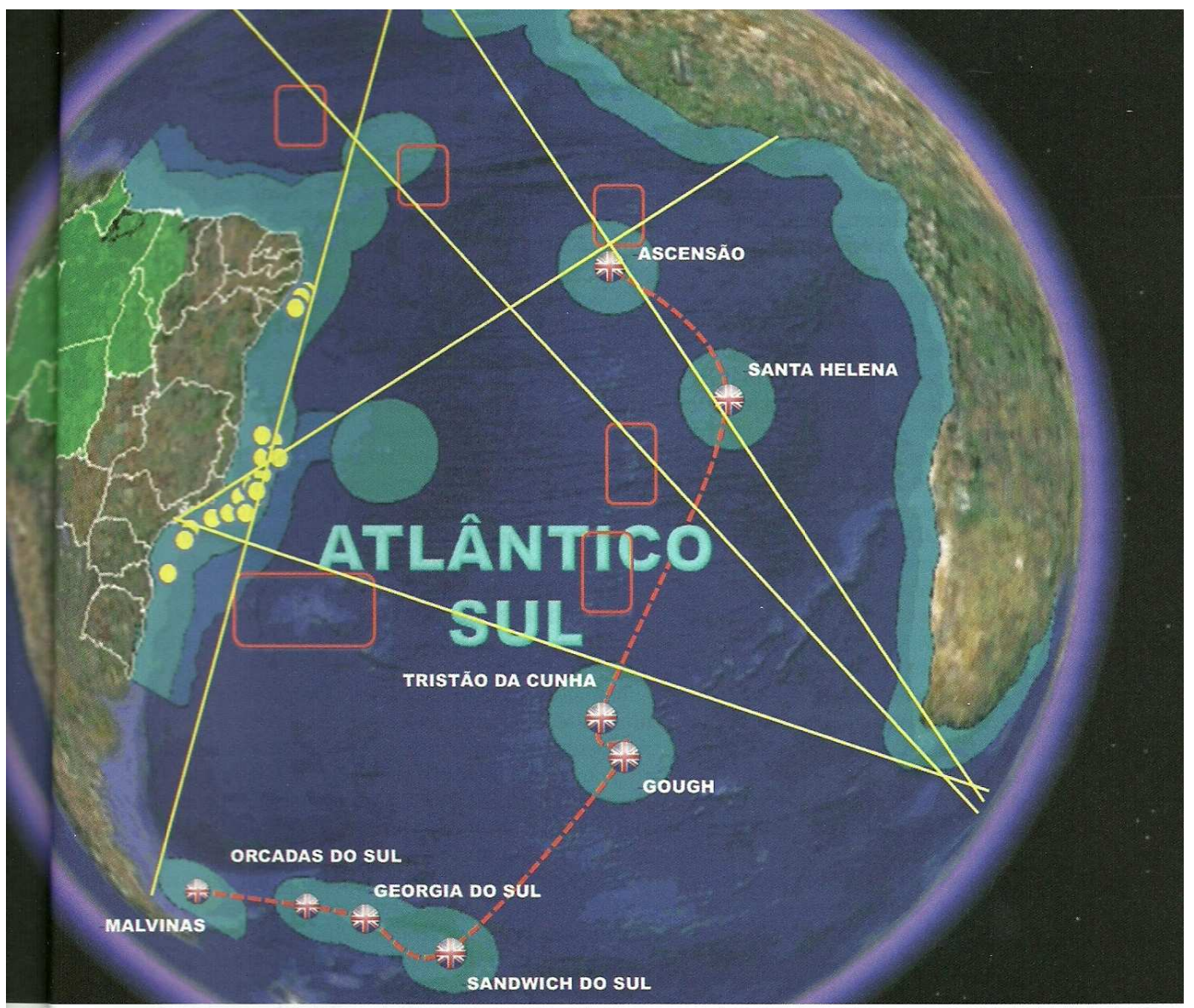

MAPA 06, fonte: www.defesa.gov.br 
As teses de Mahan guardam, igualmente, grande atualidade no que diz respeito à centralidade da América Central e do Caribe para a estratégia de segurança norteamericana, seu "primeiro cordão" de defesa, seu perímetro de segurança imediato. A postura intransigente dos Estados Unidos quanto a Cuba, recusando-se, após mais de cinquenta anos, a reconhecer a opção soberana feita por seu povo, é expressão, para além dos antagonismos ideológicos, da importância mahaniana do controle de Cuba, e assim, do Caribe, pelos Estados Unidos. Outro exemplo: a reação desproporcional dos Estados Unidos por ocasião do terremoto no Haiti, quando em questão de horas mobilizou milhares de soldados e farto armamento, o que expressa o temor com uma onda de refugiados vindos do Caribe.

Nesse contexto, vale uma pequena digressão que nos dará elementos para compreender, no Capitulo IV, o papel chave da América do Sul no pensamento estratégico norte-americano.

Aqui, há um há um velho e, todavia, atual debate que permeia a própria ascensão dos Estados Unidos no mundo, representada pela disjuntiva entre a corrente "isolacionista" e a "intervencionista".

Para a primeira, o domínio do hemisfério americano sempre foi a $1^{\text {a }}$ linha de defesa dos Estados Unidos, onde esse país deveria concentrar todas suas energias, isolando-o e blindando-o; já a segunda corrente, a intervencionista, considera o hemisfério americano a $2^{\mathrm{a}}$ linha de defesa, visto que haveria o risco do "cerco" do "novo mundo" pelo domínio do "velho mundo" por potências hostis. Assim, caberia aos EUA disputar o controle da "ilha-mundo", em especial, buscando um equilíbrio de poder, incentivando as contradições e impedindo uma aliança, a qualquer custo, entre a Europa e a Ásia ${ }^{28}$.

A despeito da ordem, seja para uma corrente, seja para outra, há um denominador comum que é a importância do domínio hemisférico como base para a hegemonia norte-americana no mundo.

${ }^{28}$ Este debate está fartamente retratado, dentre outros, no clássico "Estados Unidos frente al mundo", de Spykman. 
Um sintoma desta preocupação estratégica norte-americana é o fato de no último período, em tom alarmista, haver diversas manifestações governamentais ou de thinkthanks norte-americanas, alertando para a perda de influência desse país na América Latina, vis-à-vis, com o aumento da presença de potências extra-hemisféricas, como China, Rússia e Irã.

A partir do conceito geopolítico de anéis ou círculos concêntricos, podemos dizer que a base da expansão estadunidense no mundo foi, num primeiro momento (isto é, início do século 18), o domínio daquilo que Nicholas Spykman denominou de “mediterrâneo americano" (1942, p. 52) - a área geográfica do Caribe expandida para o norte da América do Sul.

Afinal, para Spykman, ao contrário do que "erroneamente se supõe" [...] "o continente sul-americano não funciona como uma massa geográfica homogênea", mas se trata de uma massa territorial e marítima (bacia caribenha), que vai do sul dos Estados Unidos até "as terras altas das Guianas", passando pela Colômbia e Venezuela.

Assim, um primeiro perímetro de segurança nacional dos Estados Unidos se alargaria ao norte da América do Sul, e em parte do "grande Caribe" ou "mediterrâneo americano".

Já um segundo circulo concêntrico, mais alargado, abrangeria o conjunto do hemisfério americano, incluindo a América do Sul geopolítica, no conceito de Spykman, abaixo das barreiras naturais representadas pela parte norte da Cordilheira dos Andes e pela densa floresta amazônica.

Fechamos esta pequena digressão, apoiados no geopolítico Spykman, para demonstrar que perdura o ensinamento de Mahan sobre a centralidade da área geográfica imediatamente ao sul do território norte-americano.

Diga-se, de passagem, que não é apenas os Estados Unidos que seguem as recomendações de Mahan. Segundo KAPLAN - analista do estabilishment norteamericano, portanto, obviamente, aqui não se trata de opinião neutra ou desinteressada -, a China, potência em ascensão, também o faz. Segundo ele, a China 
considera o oceano territorialmente: o próprio modo de expressão "primeiro cordão de ilhas" e o "segundo cordão de ilhas" (o segundo cordão de ilhas inclui os territórios americanos das ilhas Guam e Mariana do Norte) sugere que os chineses veem todas estas ilhas como extensões de arquipélagos da imensa superfície terrestre chinesa. Ao pensar de tal maneira, sobre os mares contíguos de seu país, os líderes navais da China estão mostrando a filosofia agressiva do estrategista naval americano Alfred Thayer Mahan, na virada do século XX, que defendia o controle do mar como a batalha decisiva (KAPLAN, 2010, p. 34, tradução nossa).

Provavelmente, inspirado em Mahan, de quem era assíduo leitor, lembra-nos KAPLAN que:

\begin{abstract}
Nicholas Spykman, o especialista em geopolítica do século XX, observou que, ao longo da história, os Estados têm se empenhado em 'expansão ultramarina e circunferencial' para ganhar controle dos mares adjacentes. A Grécia buscou controle sobre o Mar Egeu, Roma sobre o Mediterrâneo, os Estados Unidos sobre o Caribe - e agora a China sobre o Mar da China do Sul. Spykman denominou o Caribe 'o Mediterrâneo Americano' para ressaltar a sua importância para os Estados Unidos (KAPLAN, 2010, p. 37, tradução nossa).
\end{abstract}

Não deveria o Brasil ter a mesma percepção sobre o Atlântico Sul? Como, aliás, parece que a Marinha do Brasil passa a ter, a partir das propostas de seu reaparelhamento. Esta é uma das recomendações de Mahan que podem se mostrar adequadas para um país como o Brasil, dotado de grande litoral.

Vide a relativa novidade na geopolítica brasileira, neste século XXI, representada pela centralidade da Amazônia Azul, e, mais amplamente, do Atlântico Sul, no pensamento de estratégico-militar do Estado brasileiro.

Há uma maior nitidez com relação à importância geopolítica do Atlântico Sul no pensamento geopolítico brasileiro. Um exemplo recente e expressivo são os pronunciamentos de relevantes estudiosos sobre o tema, em recente ciclo organizado pelo Ministério da Defesa brasileiro, no ano de $2010^{29}$ e, mesmo, do próprio então ministro da Defesa, Nelson Jobim, que em pronunciamentos firmes, expressara

${ }^{29}$ Referimos-nos ao ciclo de cinco Seminários denominado SEGURANÇA INTERNACIONAL: PERSPSCTIVAS BRASILEIRAS, realizados nas cidades do Rio de Janeiro, São Paulo e Brasília, entre março e junho de 2010, ao qual assistimos na sua totalidade e que resultou em: JOBIM, Nelson; ETCHEGOYEN, Sergio W.; ALSINA, João Paulo. (Org.). Segurança Internacional: perspectivas brasileiras. Rio de Janeiro: Editora FGV, 2010. 
preocupação do governo brasileiro para com a ostensiva presença da OTAN defronte o litoral brasileiro ${ }^{30}$.

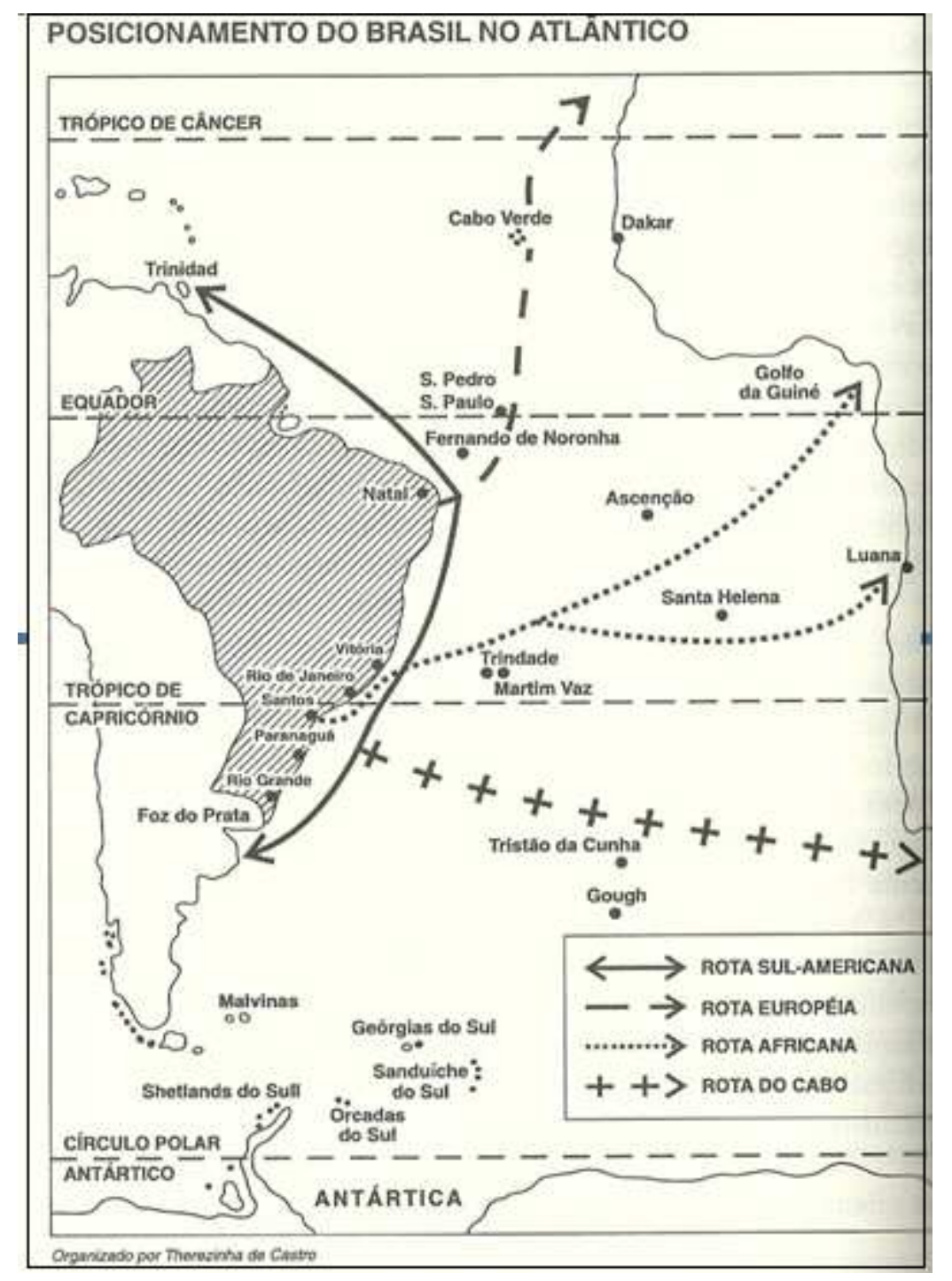

MAPA 07: CASTRO, Therezinha de. Geopolítica: princípios, meios e fins. Rio de Janeiro: Biblioteca do Exército Editora, 1999

A recomendação de Mahan, quanto à proteção dos portos, nos faz lembrar a enorme vulnerabilidade das plataformas petrolíferas da Petrobras, onde o Brasil extraí a maior parte do seu petróleo - e, assim, da grande importância do atual programa de reaparelhamento da Marinha do Brasil, sobretudo os submarinos à propulsão nuclear.

${ }^{30}$ Ver, por exemplo, "Brasil rejeita ação da Otan no Atlântico Sul" in O Estado de São Paulo, 21/10/2010, p.A21 
Da recomendação de Mahan, no que concerne à necessidade de proteger as vias de penetração interiores do território, podemos observar a decisão da nova Estratégia Nacional de Defesa, no sentido de criar a $2^{\mathrm{a}}$ Esquadra da Marinha em área próxima à foz do Rio Amazonas. Assim, de acordo com a recomendação de Mahan, a respeito da importância de fixar bases de operação para além do território, lembramos da importância, em discussão na Marinha, de criar bases navais como, por exemplo, na ilha de Trindade, que defronta o Estado do Espírito Santo, logo depois dos campos de petróleo do pré-sal.

É relevante, todavia, a defesa mahaniana da importância da proteção das linhas de comércio. Um dos exemplos mais utilizados nas demonstrações da importância desta ideia, diz respeito à região do Estreito de Malaca, no sudeste asiático, cujo bloqueio, afirmam muitos, teria a capacidade de colapsar a economia chinesa, tendo em vista o volume de mercadoria e petróleo que por lá transita para este país.

A defesa de incentivar a maritimidade, isto é, o contato com o mar por parte de um povo com base para o poder naval, também nos parece algo pertinente na atualidade para um país dotado de imenso litoral. No caso do povo brasileiro, ressalte-se que não apenas temos no sangue de nossa herança lusitana o gosto pelo mar, como, efetivamente, a maior parte de nossa população está a não mais de duzentos quilômetros do mar - o que, por outro lado, se pensarmos em termos mackinderiano, revela uma debilidade estratégica, em especial, por concentrar grande parte da riqueza nacional próxima ao oceano.

A própria transferência da capital, do Rio para o planalto central - proposta feita originalmente por José Bonifácio de Andrada e Silva, muitos antes de Mahan ter escrito seu famoso livro, ou de Mackinder ter proferido sua igualmente famosa conferência foi fruto da identificação desta vulnerabilidade. Da mesma forma, a Estratégia Nacional de Defesa menciona a vulnerabilidade representada pela concentração de nosso parque industrial aeroespacial em São José dos Campos, a poucos quilômetros do litoral norte paulista.

Também nos parece relevante mencionar o debate proposto por Mahan sobre o caráter do governo. Compreendemos esta questão como a defesa e a centralidade do 
interesse nacional como condição para a projeção de poder. Governos pusilânimes em relação ao interesse nacional, certamente, não podem exercer poder soberano.

Por fim, possui grande atualidade o debate proposto por Mahan acerca do caráter ofensivo versus caráter defensivo do poder naval, com a defesa mahaniana do caráter ofensivo das Esquadras. Aliás, a defesa de uma postura altamente ofensiva do poder marítimo coaduna-se com a visão, segundo a qual Mahan é um apologista - a de uma postura imperialista.

Há quem defenda que a postura da Marinha do Brasil, a partir da Estratégia Nacional de Defesa, de privilegiar meios estratégicos que nesta interpretação seriam tipicamente dissuasivos, como o submarino à propulsão nuclear, revelaria uma postura contrária a visão proposta por Mahan para o asseguramento do poder naval ${ }^{31}$. Por certo, trata-se de tese altamente controversa.

O ponto maior de superação e anacronismo em Mahan é sua visão, carregada de etnocentrismo, sobre o caráter nacional. Aqui, o almirante norte-americano adere às teses correntes à época - e, porque não, até hoje, da visão média norte-americana - a respeito de povos superiores e povos bárbaros.

A valorização dos povos empreendedores em detrimento dos "povos coletores" - expressão utilizada largamente por Sergio Buarque de Holanda em Raízes do Brasil é absolutamente falsa, tendo em vista a formação social brasileira. O mestre da brasilidade, Gilberto Freyre, tratou de fazer cinzas deste tipo de visão. Em trabalho de conclusão da graduação, discutimos em profundidade esta superação produzida por Freyre $^{32}$. Além disso, para além do aspecto sociológico, a crescente relevância brasileira no concerto das nações - e de grandes países em desenvolvimento - e, por outro lado, a flagrante decadência europeia, derrubam teses eurocêntricas, como a defendida por Mahan, a respeito do caráter nacional.

\section{Algumas permanências e descontinuidades em MACKINDER}

\footnotetext{
${ }^{31}$ Referimo-nos aqui as teses defendidas em conferência apresentada oralmente pelo Capitão de Mar-e-Guerra Francisco Eduardo Alves de Almeida, em agosto de 2010, no 6ํㅡㄹ Ciclo de Geopolítica da ECEME (Escola de Comando do Estado Maior do Exército), na qual estivemos presentes.

${ }^{32}$ Ver CARMONA. Formação social Brasileira: uma introdução ao debate. 2006
} 
Observando a situação estratégica global, há muitas razões para se defender a ideia de que a grande ilha mundial mackinderiana, e mais especificamente a Eurásia para além de ser o heartland, a partir do qual se dominaria o mundo -, certamente, é cenário central no equilíbrio de poder e na balança de forças no mundo.

$O$ continente geopoliticamente central do mundo e suas periferias é melhor percebido quando o mapa é invertido em relação a forma como conhecemos:

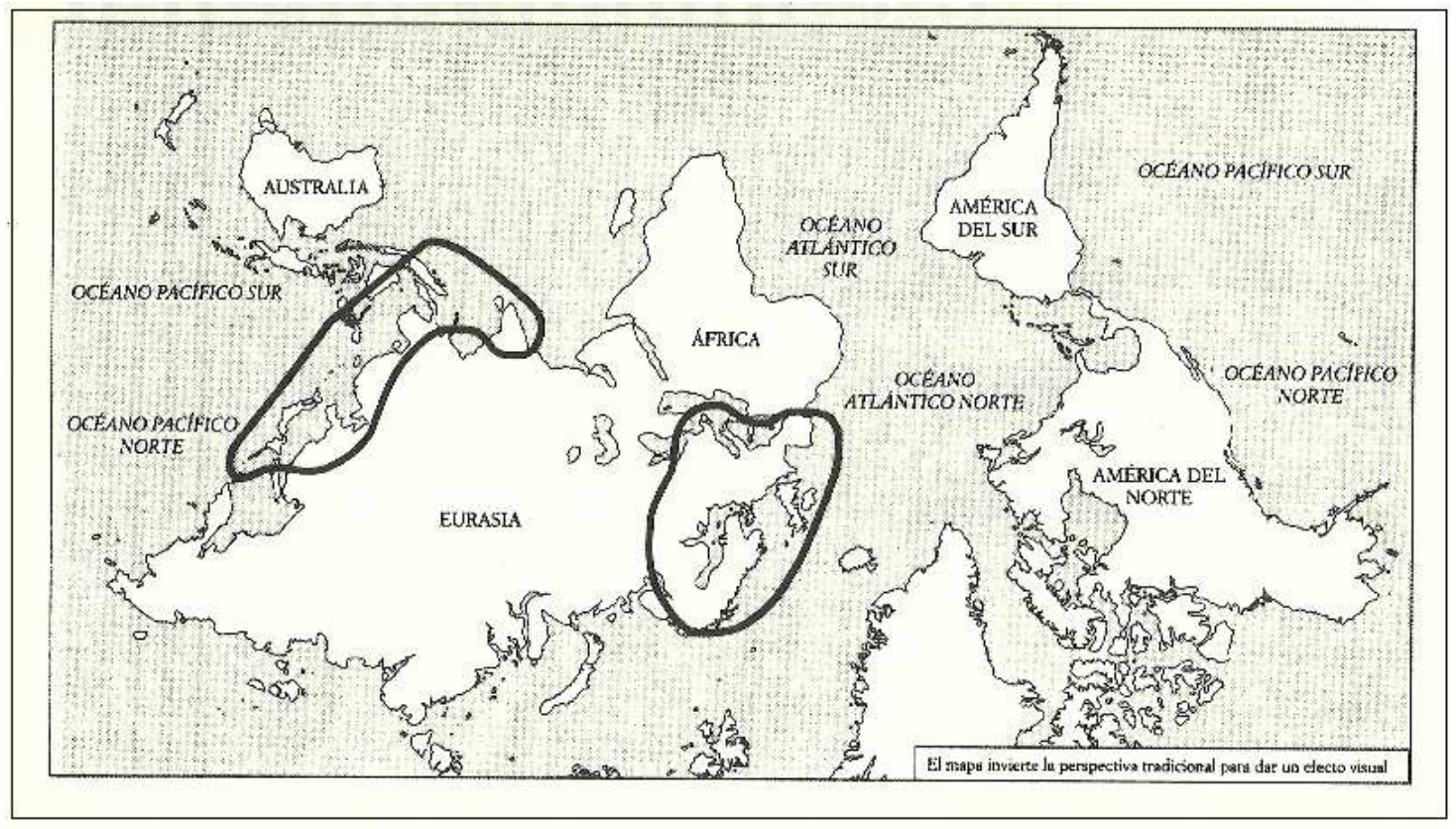

MAPA 08: BRZEZINSKI, Zbigniew. El gran tablero mundial: la supremacia estadunidense y sus imperativos geoestratégicos. Barcelona: Paidós, 1998. p. 41.

Primeiro porque, como lembra Brzezinski, "a potência que domine a Eurásia poderá controlar duas das três regiões do mundo mais avançadas e economicamente mais produtivas" (1998, p. 39). O geopolítico norte-americano, de origem polonesa, escreveu em 1997 um conhecido estudo, visando demonstrar que mesmo com o fim da 
guerra fria, se mantinha a centralidade da Eurásia como "tabuleiro geoestratégico mundial",33.

Brzezinski argumenta que:

\begin{abstract}
a Eurásia é também o lugar onde estão situados a maior parte dos Estados do mundo politicamente ativos e dinâmicos. Depois dos Estados Unidos, as seguintes seis economias mais importantes e os seguintes seis países cujo gasto em armamento militar são mais elevados estão na Eurásia (BRZEZINSKI, 1998, p. 46).
\end{abstract}

Além disso, "todas as potências nucleares reconhecidas" estão na Eurásia. Contudo, Brzezinski ao defender a manutenção da centralidade da Eurásia, dando razão a Mackinder, também propõe uma atualização do preceito mackinderiano. Afirma que:

\begin{abstract}
na atualidade, a principal questão geopolítica não mais é a que parte da geografia da Eurásia como ponto de partida para o domínio continental, nem tampouco a questão se o poder terrestre é mais significativo que o poder naval. A geopolítica deslocou-se da dimensão regional para a global, considerando que a preponderância sobre todo o continente eurasiático é a base fundamental da supremacia global" (BRZEZINSKI, 1998, p. 47).
\end{abstract}

Há muitos fatores a recordar a atualidade das teses do geógrafo inglês, Halford Mackinder. Uma das mais recorrentes, ou melhor, uma das chaves de análise do quadro internacional - um dos cenários que se propõe para o futuro próximo -, é o de um contexto internacional marcado pela existência de um G-2, no qual Estados Unidos e China seriam os dois polos de uma nova bipolaridade ${ }^{34}$ e, porque não, de disputa da ilha-mundial eurasiana. Ainda que a ideia de um G-2 nos pareça alarmista e exagerada, na verdade parte de uma percepção sinofobica dos países ocidentais, estimulada pelos grandes meios de comunicação, de fato ocorre uma disputa de protagonismo e mesmo de hegemonia na região da Ásia Central.

Certamente, a era atual observa um deslocamento do eixo geoestratégico do Atlântico Norte para o Pacifico, o que se trata de uma espetacular novidade, tendo em vista o cenário dos últimos séculos. Na verdade, neste cenário, pela primeira vez desde as navegações de Colombo, o Atlântico perderia a centralidade entre os oceanos.

${ }^{33}$ BRZEZINSKI, Zbigniew. El gran tablero mundial: la supremacia estadunidense y sus imperativos geoestratégicos. Barcelona: Paidós, 1998.

${ }^{34}$ Cf. GLOBAL GOVERNANCE 2025: AT A CRITICAL JUNCTURE, de setembro de 2010, publicado pelo National Intelligence Council do governo norte-americano. Disponível em: <http://www.dni.gov/nic/PDF 2025/2025 Global Governance.pdf>. Acesso em: 01 dez. 2010. 
Ao mesmo tempo, estaria ocorrendo, como dissemos anteriormente, um deslocamento no polo mais dinâmico da Eurásia, que estaria se deslocando de sua extrema periferia ocidental - a Europa ocidental - para sua extrema periferia oriental - a China.

No que diz respeito à situação contemporânea da Eurásia, analistas como FIORI (2010) e o professor Francisco Carlos Teixeira, ambos da UFRJ, apresentam analogias entre o período atual e o daquele conhecido como o do chamado Grande Jogo.

Teixeira defende que poderíamos estar vivendo um novo período similar ao do Grande Jogo, ocorrido na Ásia Central no século XIX, que seria representativo da atualidade de algumas das teses de Mackinder ${ }^{35}$. Afinal, naquele período, entre a Índia britânica e as regiões periféricas do Império Russo, produziu-se uma grande disputa, com centro no Afeganistão - envolvendo, também, a Pérsia (atual Irã) e a região do Tibete/Xinjiang, áreas remotas do Império chinês -, pela hegemonia da região.

Por um lado, havia o antigo desejo russo de possuir acesso ao Oceano Índico; por outro, as iniciativas britânicas para conter esta aspiração russa, tendo em vista as grandes consequências estratégicas que delas adviriam - se considerarmos, por exemplo, as teses de Mahan. É parte deste Grande Jogo, por exemplo, a criação britânica do Estado-tampão do Paquistão - e, posteriormente, a transferência estadunidense de poder nuclear a esse país, mesmo que contrariamente às regras do sistema internacional. O objetivo britânico era a proteção da Índia, sua colônia, da Pérsia e das rotas de comércio; já o americano, armando o Paquistão, visava gerar uma balança de poder frente à Índia não-alinhada.

Dentre outros importantes analistas internacionais, que defendem estarmos vivendo uma reedição do Grande Jogo, está, como vimos, Zbigniew Brzezinski, que incorpora largamente as teses mackinderianas sobre o heartland e sua centralidade na era atual.

Observando o cenário internacional, parece-nos mais correto falar num Grande Jogo que opõe, de um lado, os Estados Unidos e seus aliados europeus da OTAN, e, do

\footnotetext{
${ }^{35}$ Ideia apresentada oralmente em palestra sobre Mackinder e Haushofer, em agosto de 2010, no 6ํㅡ Ciclo de Geopolítica da ECEME (Escola de Comando do Estado Maior do Exército), a qual estivemos presentes.
} 
outro lado, a China - fortemente preocupada com pressões centrífugas em sua fronteira ocidental remota, sobre os muçulmanos chineses de Xinjiang e os chineses tibetanos - e a Rússia -, que após o fim da União Soviética vê erodir sua presença na Ásia Central um objetivo estratégico do país desde os czares.

Desse modo, há razões suficientes para acreditar que, na secular luta entre o chamado "urso" russo e a "baleia" norte-americana, vem se somar - ao lado do urso - o dragão chinês.

Essa disputa se expressa na contenda, por um lado, da China e Rússia, conformando uma aliança no âmbito da Organização de Cooperação de Xangai, e do outro, EUA e os europeus, no âmbito da OTAN, em sua missão civilizadora - até agora absolutamente frustrada - no Afeganistão.

Neste último caso, EUA e OTAN, além de criarem um protetorado no Afeganistão, com a imposição de um governo títere e fraco, cuja autoridade se resume a capital Cabul, realizam forte assédio sobre a Índia ${ }^{36}$ e põem no centro da mira o governo islâmico do Irã - um governo autônomo, que persegue projeto nacional próprio.

Acerca do Irã, aliás, teve grande impacto a assinatura do chamado Acordo de Teerã, em maio de 2010, em que três países em desenvolvimento desnuclearizados (ademais do Irã, Brasil e Turquia) se pronunciaram a respeito de tema estratégico, de exclusivo manejo das potências nuclearizadas, em defesa do direito, consagrado nas normas internacionais, de domínio de tecnologia de produção de energia nuclear com fins pacíficos. A forte reação que se seguiu, em especial por parte dos Estados Unidos, mostra a centralidade que a questão iraniana - e, por que não, de assuntos relativos à Eurásia - tem para esse país ${ }^{37}$.

\footnotetext{
${ }^{36}$ Ainda no governo Bush, numa concessão absolutamente pragmática norte-americana tendo em vista que a Índia é um dos quatro países nuclearmente armados não autorizados pelo "sistema internacional" - foi assinado um curioso acordo nuclear entre os dois países. Mais recentemente, no final de 2010, Obama visitou a Índia, onde além de assinar diversos acordos novos, declarou apoio ao ingresso indiano no Conselho de Segurança das Nações Unidas. Claros sinais de assédio norte-americano à Índia, no contexto de sua geopolítica contemporânea de contenção da China.

${ }^{37}$ Em CARMONA (2010b) desenvolvemos análise sobre o acordo de Teerã e as repercussões para a política externa brasileira.
} 


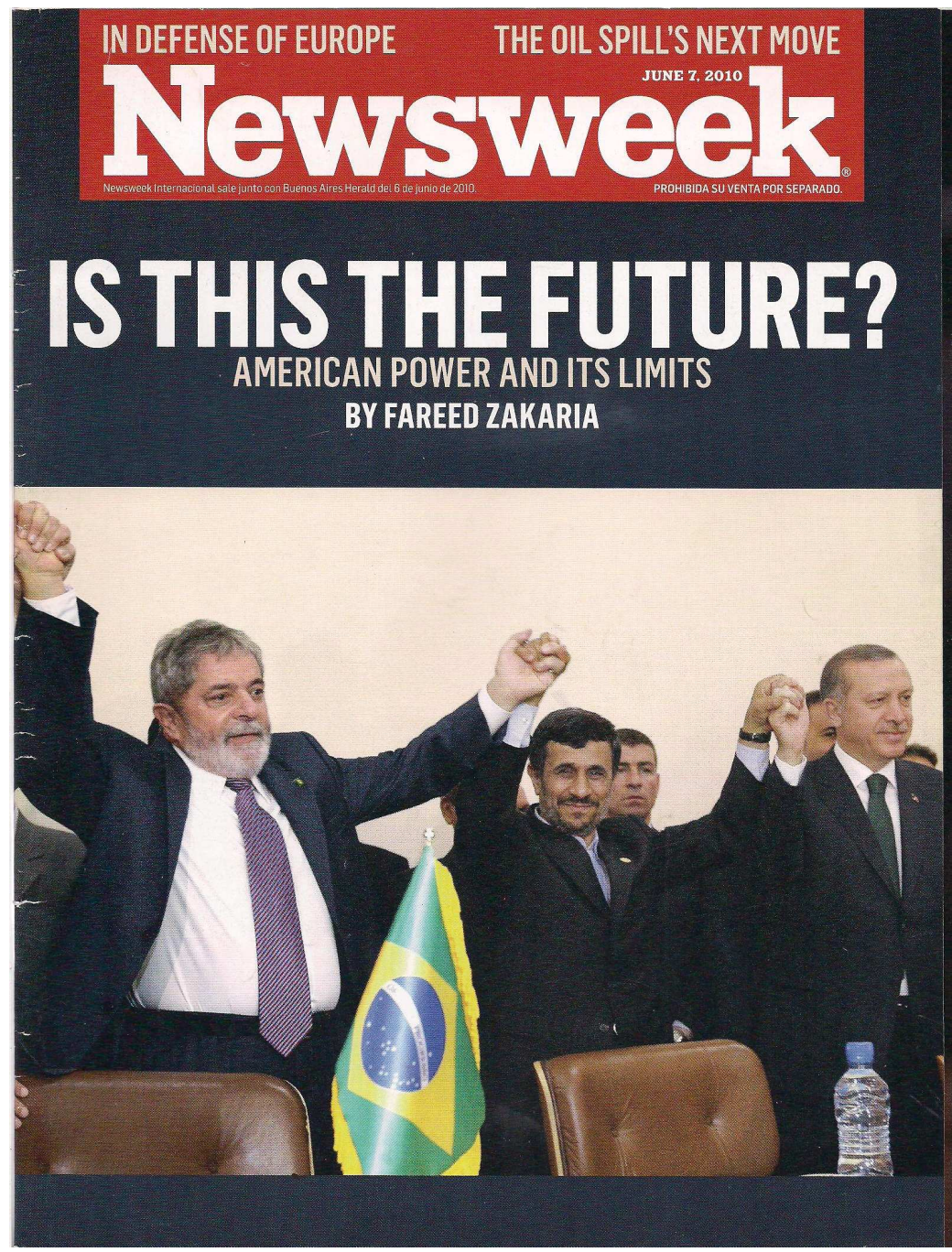

\section{ILUSTRAÇÃO 01}

Além de objetivos estratégicos, há nítidos objetivos econômicos na disputa atual pela Ásia Central: por exemplo, no controle da rede de oleodutos que levam suprimentos energéticos à Europa, por um lado, e à China, por outro. Elemento que não existia, por exemplo, em 1904, quando Mackinder fez sua famosa conferência.

Além disso, trava-se na Ásia Central um jogo, cujo objetivo parece ser o de ameaçar a integridade territorial chinesa. Além do Tibet, a província de Xinjiang tem registrado distúrbios étnicos. Segundo KAPLAN,

Xinjiang, o nome da província mais ocidental da China, significa 'domínio novo' e refere-se ao Turquestão Chinês, uma área de duas vezes o estado do Texas que encontra-se a grande distância da área central da China no outro lado do Deserto de Gobi (KAPLAN, 2010, p. 25). 
Assim, "a fim de proteger estas áreas - e o petróleo, o gás natural, o cobre, o minério de ferro em seu solo -, Pequim vem há décadas povoando-as com os chineses Han da área central do país" (KAPLAN, 2010, p. 25).

No grande jogo mackinderiano, travado na Ásia Central, poderia uma aliança sino-russo-indiana dominar a world island - como imaginou Mackinder que pudesse a vir ocorrer no caso de uma aliança russo-germânica? Há razões para imaginar que sim, inclusive pela movimentação diplomática e estratégica do império norte-americano no sentido de fraturar essa aliança.

Aliás, mais do que nunca, observando a atualização da visão estratégica norteamericana, parece estar viva a advertência visionária de Mackinder sobre o perigo amarelo chinês, com a qual termina seu célebre texto sobre o pivot geográfico da história.

O mais provável, no entanto, é que se Mackinder fosse vivo não seria a Alemanha sua preocupação principal. Afinal, esse país, e mais amplamente a Europa, decadente e estrategicamente prostrada ao projeto estadunidense, têm reduzida capacidade de iniciativa própria, sendo na prática um apêndice no projeto norteamericano $^{38}$.

Ainda que a Alemanha desempenhe papel de carro-chefe no que diz respeito à economia da União Europeia - sendo núcleo, junto com França e Grã-Bretanha, de uma troika condutora do modelo em curso de integração no velho continente -, do ponto de vista estratégico, desde o final da segunda guerra mundial, logrou-se impedir que o demônio levantasse a cabeça nesse país, para usar uma expressão mackinderiana. A verdadeira ocupação do território alemão, por dezenas de bases militares norteamericanas, é exemplo disto.

Mackinder chamava atenção para a necessidade de se criar uma zona de contenção entre a Alemanha e a Rússia, visando impedir uma coalizão entre os países. Em certa medida, isto está absolutamente realizado hoje, após o fim do bloco socialista no leste da Europa. Assim, quem vê, atualmente, a presença norte-americana e alemã no

${ }^{38}$ Como afirmou o então ministro da Defesa, Nelson Jobim, na Conferência do Forte de Copacabana, em novembro de 2010, no Rio de Janeiro, "tudo isso leva a crer que a União Européia não se tornará um ator geopolítico à altura de seu soft power nos próximos 30 anos". 
Leste Europeu percebe que os EUA não se esqueceram das recomendações de Mackinder $^{39}$.

Em sua famosa obra $O$ choque das civilizações, Samuel P. Huntington, dizia que “de fato, no final dos anos 1990, a principal ameaça à estabilidade e ao equilíbrio de poder na Eurásia parece ser a possibilidade de um importante vácuo de poder, surgindo no coração do mundo de Mackinder" (HUNTINGTON, 1998, p. 28).

No entanto, quem observa a instabilidade na região - cujo exemplo maior é o Afeganistão - percebe que mais do que o vácuo de poder, o que existe, atualmente, é uma feroz disputa, que lembra o velho grande jogo.

Já a ideia de um sistema mundial fechado é ainda mais verdadeira hoje do que era em 1904. Ao ingressarmos na segunda década do século XXI, podemos dizer que o mundo encontra-se integrado num todo, mundializado, praticamente sem áreas despovoadas, se não em função de razões físicas ou climáticas extremadas. "Globalizado", entretanto diverso: a base da organização humana, a despeito de visões apologéticas dos anos 1990, segue sendo a nação, o Estado nacional.

Estamos de acordo com o argumento de HUNTINGTON (1998), para quem, a despeito da "globalização", vivemos num mundo de civilizações, no qual as identidades nacionais têm grande preponderância. O sistema fechado não representou, portanto, o fim das nacionalidades, ao contrário, num contexto de pressão uniformizante, as identidades cada vez mais se afirmam.

Esta última questão levanta outra, igualmente relevante para o pensamento de Mackinder. Trata-se de sua preposição, de grande atualidade, a respeito da possibilidade de coesão nacional frente às ameaças externas. Cada vez mais, a chamada questão nacional - sobretudo quando defrontada com ameaças externas, de natureza imperialista - é motor de coesão, emulação e motivação das nações e dos povos.

\footnotetext{
$* * *$

${ }^{39}$ No auge da rejeição internacional à George W. Bush, o presidente norte-americano chegou a ser recebido como verdadeiro pop star em Tirana, capital da Albânia. Obama, pouco depois de ser eleito, fez um gigantesco comício em Praga, capital da República Tcheca. Muitos outros exemplos, aqui, poderiam ser dados neste sentido.
} 
Mackinder, por certo, também apresenta flagrantes anacronismos. Por exemplo, não se aplica a era atual sua visão de natureza profundamente etnocêntrica, a respeito da “civilizatória missão do homem branco" - a despeito da evidente atualidade da doutrina do "destino manifesto" ou da democracia como valor universal. Melhor dizendo, ainda que se aplique, na era atual, estas teses são precisamente percepções eurocêntricas que contrariam interesses mais amplos dos povos do mundo.

Nesse sentido, ainda que, por certo, alguns governos norte-americanos sigam autodefinindo para si essa "missão" - naquilo que COSTA, citado na resenha sobre o pensamento de Mackinder, chamou de idealismo democrático do autor.

Julgamos que não há um sistema de governo único, nem haverá uma ideologia única dominante em todo o globo, pelo menos por um prolongado período histórico um mito defendido por Mackinder, em seu Ideais democráticos, e mais recentemente, na esteira da euforia do fim da URSS, por personagens como Francis Fukuyama e outros.

Também é profundamente datada a visão de Mackinder de valorizar a civilização do homem branco em detrimento de outros povos - um anacronismo que revela, no conjunto de sua obra, uma visão eurocêntrica.

Mas aqui cabe uma ressalva, proposta por MELLO. Ao contrário da cartografia de Mercartor, Mackinder,

como inovador, rejeitou o eurocentrismo da cartografia tradicional (...) porque desloca a Europa do centro do mapa-múndi, mostrando-a como uma pequena península ocidental do grande continente eurasiano, cuja posição nuclear passou a ser ocupada pela Pivot Area (MELLO, 1999, p. 195).

No entanto, se na cartografia Mackinder questiona o eurocentrismo - talvez pela objetividade de sua condição de geógrafo, o mesmo não se pode dizer de sua visão de mundo, sobretudo a respeito da crença na superioridade ocidental e anglo-saxã.

Por fim, no que concerne às superações é valido resgatar as observações de MELLO (1999, p. 194), segundo que, "há pelo menos dois fenômenos cruciais cujas implicações geopolíticas e estratégicas não foram inteiramente percebidas pelo geógrafo britânico: a evolução da cartografia e o avanço da tecnologia". No primeiro caso, por ter 
Mackinder baseado suas teses em mapas-múndi de projeção cilíndrica, ao passo que "ao longo do século, a projeção azimutal equidistante enriqueceu a cartografia, com um diversificado leque de configurações geopolíticas e estratégicas" (1999p. 197).

Já a segunda questão, é recorrente entre os críticos de Mackinder. Nesse contexto, MELLO (1999, p. 202-211) crítica a subestimação por Mackinder do aparecimento do poder aéreo, aliás, a mesma crítica que aparece em ARON (1986). À propósito, são nas obras do autor francês que se vê uma das mais contundentes críticas a Mackinder, no sentido de propor sua superação. Sua autoridade, ao criticar Mackinder, é ainda maior por se tratar um autor clássico das teorias realistas.

Diz ARON (1986, p. 268), que "relido em 1960, o geógrafo inglês parece ter tido a pior das sortes possíveis para um conselheiro do Príncipe: foi ouvido pelos estadistas, mas ignorado pelos acontecimentos". Isso porque, segundo ele:

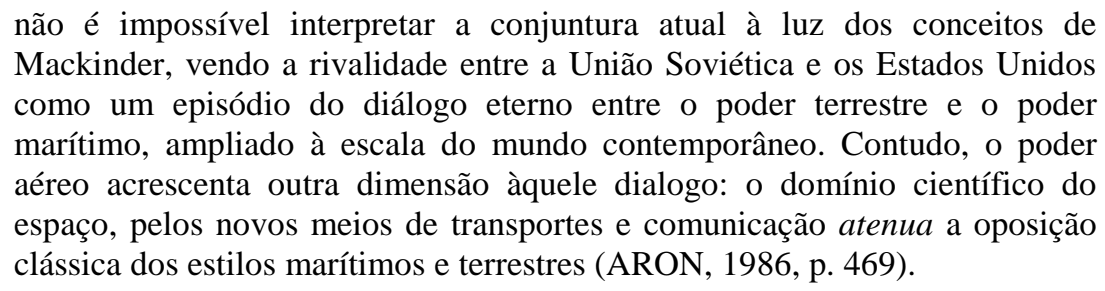

Esta crítica se soma a de outros autores que defendem o anacronismo de Mackinder pela suposta superação de sua tese básica, de primazia do poder terrestre, tendo em vista o avanço da tecnologia do poder aéreo.

No entanto, parece-nos que é necessária vê-la sob um duplo e contraditório ângulo. Isso porque, diante desta questão - se o poder aéreo superou a primazia do poder terrestre -, parece-nos que não há uma resposta única.

Não porque, como demonstram as bases aéreas norte-americanas espalhadas ao redor do mundo - dando razão a Mackinder -, é relativa a autonomia dos aeroplanos, mesmo os mais avançados tecnologicamente, com maior autonomia de vôo, seguem dependentes da retaguarda em terra, como disse o geógrafo inglês.

Mas, também, tem razão os que advogam a importância do poder aéreo, pois, de fato, uma marca da era atual, em termos de armas estratégicas, é a existência de vetores com imenso poder de destruição, que vai de armas nucleares de diferentes intensidades, 
passando por mísseis intercontinentais, inclusive convencionais, indo até a realização de guerra a partir do espaço ou pelo mar, a partir de submarinos.

Entretanto- num argumento que reforçaria as teses de Mackinder, mas que não estava posto à época -, como mostra o Iraque e o Afeganistão, e, mais recentemente, a Líbia, superioridade tecnológica, quer no ar, quer na terra, não é tudo; uma coisa é arrasar o Exército de Saddam Hussein, as forças regulares afegãs dos Talibãs ou, ainda, acuar as forças de Kadafi. Outra bem distinta é o enfrentamento da guerra assimétrica, travada no terreno, onde as forças terrestres podem, sim, ter grande vantagem mesmo em relação a forças absolutamente superiores em termos de armamento e tecnologia. Neste sentido, é preciso observar a falácia de certas teses, em estudos estratégicos, que creditam a tecnologia em si o poder determinante na guerra moderna.

\section{Pontos de contato e de oposições entre Mahan e Mackinder}

No geral, a literatura em geopolítica busca destacar a oposição entre Mahan e Mackinder. De fato, como ressalta Mackinder, há uma disjuntiva histórica entre terra e mar que vem de Roma e da Grécia antiga, no que tange à civilização ocidental enquanto "os romanos-teutones se lançaram ao mar, os gregos-eslavos cavalgaram pelas estepes conquistando os tarânios", diz Mackinder.

Fora da civilização ocidental, também o antigo "Império do Meio" (a civilização chinesa) se defrontou entre os dois caminhos, oscilando, por exemplo, nos últimos cinco ou seis séculos, entre a condição de grande potência, que navegava pelo mundo a fora ${ }^{40}$, e, na sequência, o isolamento territorial completo, quando, chegou a transferir populações do litoral para o interior.

Assim, o problema da oposição entre poder naval versus poder terrestre - ou mais amplamente, da opção entre a maritimidade e a continentalidade - é, antes de tudo, um dilema geo-histórico humano que vem de longe.

\footnotetext{
${ }^{40}$ No livro "1421: O ano em que a China descobriu o mundo", do historiador britânico Gavin Menzie, encontramos a afirmação de que os chineses chegaram às Américas setenta anos antes de Colombo Cf. MENZIE, Gavin. 1421: O ano em que a China descobriu o mundo. Tradução Maria Eduarda Colares. Lisboa: Dom Quixote, 2004.
} 
À despeito das decantadas diferenças, em que esta a que acabamos de nos referir, e que é a mais conhecida, há importantes pontos de contato entre Mahan e Mackinder.

O primeiro deles, que gostaríamos de abordar, crucial neste século XXI sobretudo para um país como o Brasil - é a absoluta valorização que ambos fazem, da posse de vastos recursos naturais, por um lado e por outro, do fator posição do território.

Mahan faz constante alusão à importância do potêncial econômico, territorial e marítimo. Por sua vez, Mackinder, ademais de ter como fator central para sua visão acerca da inexpugnabilidade do heartland a abundância de recursos naturais, possui um sistema de pensamento que confere centralidade ao território e à sua posição. Este autor faz ainda defesa explícita das enormes potencialidades futuras da América do Sul e da África.

Estamos convencidos de que, para além da centralidade da Eurásia, e mesmo havendo um relativo descolamento do eixo atlântico para o pacífico, a ampla posse de recursos naturais e terras agricultáveis na América do Sul e na África farão destas regiões base de intensas disputas geopolíticas de natureza neocolonialistas.

É de grande importância o alerta de Mahan - formulado no final do século XIX, tendo em mente o seu próprio país -, quanto à contradição entre grande potencialidade e debilidade estratégica. Argumento que atende a necessidade de incrementar, no caso brasileiro, nossa capacidade de defesa.

Façamos, aqui, uma pequena digressão, que embora momentaneamente nos afaste dos pontos de contato, faz-se necessária. Afinal, no caso brasileiro, especificamente, como observa COSTA, possuímos:

recursos hídricos abundantes, praticamente todo o potencial hidrelétrico remanescente do país, algumas das maiores províncias minerais do mundo (incluindo "minerais estratégicos") e a mais formidável diversidade biológica do planeta (COSTA, 2007, p. 119-120).

O problema da securitização dos recursos naturais é uma das principais questões geopolíticas deste início de século XXI. Aqui, Mahan e Mackinder, como observamos, têm questões importantes a nos dizer. 
Trata-se, assim, de um debate central para o Brasil. Na questão amazônica, cabe destacar a relevante observação de COSTA:

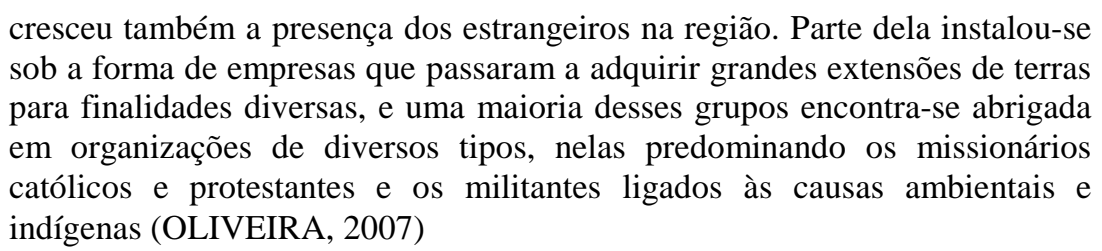

Estes estrangeiros, prossegue o autor, chamam atenção por:

\begin{abstract}
sua crescente desenvoltura nos diversos fóruns de debate, nos movimentos sociais em geral e, inclusive, em torno ou no centro do aparelho de estado. Ademais, programas de grande envergadura conduzidos nos anos recentes pelo governo e destinados à proteção das suas florestas - caso do PPG7 contam com doação integral de governos estrangeiros, com forte e óbvia participação dos seus representantes no processo da sua implementação (OLIVEIRA, 2007).
\end{abstract}

Aliado à isso, a presença estrangeira na Amazônia esteve focada na:

demarcação de terras indígenas no Médio e Alto Rio Negro e no Alto Solimões, na segunda metade dos anos noventa, (que) foi integralmente executado com recursos doados pelo governo da Alemanha, e conduzido sob a coordenação de uma ONG brasileira e a supervisão da agência de cooperação técnica daquele país. Trata-se de projeto que envolveu um montante de recursos de duas dezenas de milhões de euros, e que foi responsável pela demarcação de terras indígenas compreendendo um total de mais de $200.000 \mathrm{Km}^{2}$, uma área equivalente ao estado de São Paulo (OLIVEIRA, 2007)

Essa breve digressão serve para realçar uma das vulnerabilidades brasileiras mais importantes, relacionadas à utilização da questão ambientais como instrumento de luta no jogo de poder no sistema internacional.

Em termos de debate estratégico, há uma importante coincidência entre Mahan e Mackinder, no que diz respeito à defesa da mobilidade e do fator surpresa como premissa básica para vitórias estratégicas. Nesse sentido, é central em Mahan, a valorização, a importância do elemento surpresa, isto é, da postura não estacionaria, não estática dos meios navais. Trata-se de uma questões que foram efetivamente incorporadas na doutrina da guerra: a mobilidade e a surpresa frente ao inimigo é uma questão chave e consolidada na estratégia militar contemporânea.

Também, em Mackinder, o problema da mobilidade é central na obtenção de superioridade estratégica. Dos camelos e cavalos da época antiga, passando pela valorização da ferrovia, como meio de mobilidade, e, mais ao final de sua elaboração, 
dos veículos motorizados, é grande a ênfase do referido autor no que concerne ao tema da mobilidade.

A importância atribuída a mobilidade é uma recomendação comum à Mahan e Mackinder, a qual está plenamente incorporada à doutrina militar contemporânea.

Nesse contexto, um exemplo recente e caro ao debate geopolítico brasileiro refere-se às motivações estadunidenses para o estabelecimento de bases militares na Colômbia - para COSTA (2007, p. 125), a "presença militar dos EUA na Colômbia é o fato político-estratégico mais importante para a segurança regional sul-americana". Um importante documento norte-americano, apresentado no âmbito da UNASUL (União das Nações Sul-americanas), denominado En route strategy for Africom support, de março de 2009, mostra a função da Base aérea de Palanquero, na Colômbia, no contexto de uma rede de bases - que no caso especifico, tem sua continuidade na ilha de Ascensão, no Atlântico Sul -, que visa aumentar a eficiência estratégica da Força Aérea norte-americana. Uma base, aliás, nas fronteiras da Amazônia verde brasileira; a outra, defrontando a Amazônia azul.

Também na nova Estratégia Nacional de Defesa brasileira está presente a ideia das Forças Armadas brasileiras atingirem a recomendação mahaniana - mackinderiana de adquirir mobilidade estratégica, sendo capaz de possuir meios para atingir qualquer ponto do território nacional com grandes quantidades de tropas em poucas horas.

Outro tema presente em Mahan e Mackinder, diz respeito à valorização por ambos, da grandeza do território, ainda que com ressalvas e cada qual com suas motivações específicas.

Em Mahan - após valorizar a extensão do território, em especial do litoral -, há uma advertência acerca da vulnerabilidade de um grande território com pouca população. É uma advertência que nos serve, tendo em vista ser o Brasil, relativamente ao seu território, país de uma população diminuta, concentrada em grande conglomerados urbanos como São Paulo e Rio de Janeiro.

Em Mackinder, também, encontramos a valorização de grandes espaços territoriais. Aqui, coerente com a ideia da fortaleza da terra coração, ele o faz tendo em vista - além dos recursos naturais, como já vimos, comum a ambos - a importância e 
vantagem estratégica para países que possuem grandes territórios, no que diz respeito à possibilidade de utilização de retaguarda. Numa analogia, seria a Amazônia nosso inexpugnável heartland sul-americano?

Por fim, para além da decantada diferença Mahan - Mackinder (poder naval versus poder terrestre) parece-nos importante registrar, também, outra relevante diferença entre ambos. Trata-se, por um lado, da defesa mahaniana - até como forma de fundamentar sua posição de primazia do mar -, da estreita relação entre conformação física e prosperidade, tendo em vista sua defesa do comércio exterior como caminho ao desenvolvimento.

Aqui, há uma importante diferença com o pensador Mackinder. Enquanto Mahan vê o comércio exterior como único caminho à prosperidade aquele chega a defender - igualmente coerente com sua tese acerca da inexpugnabilidade do heartland -, a possibilidade de constituir sistemas autárquicos, tendo em vista a existência de um grande território e recursos naturais.

Quando extremadas, parece-nos que as duas posições são anacrônicas. Afinal, tanto defender a exclusividade do comércio exterior como possibilidade de desenvolvimento, quanto à possibilidade de desenvolvimento exclusivamente autárquica, não cabem neste mundo do século XXI.

À guisa de conclusão deste capítulo, manifestamos nossa concordância com a resposta de uma conhecida obra de referência na geopolítica brasileira, derivada de tese de doutoramento apresentada no Departamento de Ciência Política desta Universidade, cuja pergunta é: "em que medida tornou-se obsoleto ou permanece atual o pensamento geopolítico de Mackinder"?

Subscrevemos a resposta do professor a sua própria pergunta - reservando-nos o direito de estendê-la também a Alfred Mahan. Diz MELLO (1999, p. 193-194) que: “o pensamento de Mackinder padece, em certos aspectos, de uma visível obsolescência, ao mesmo tempo em que revela, em muitos outros, uma inegável atualidade, como sói acontecer, de resto, com o pensamento de todos os outros atores clássicos". 
A utilização explícita ou implícita, em parte ou no todo, de conceitos e visões de Mahan e Mackinder, por grandes geopolíticos e estrategistas, ao longo do século XX tais como Spykman, Kennan, Brzezinski e Kissinger, para falar de alguns dos principais - são demonstrações da perenidade dos dois autores em questão. 


\section{CAPÍTULO III}

\section{As grandes tendências geopolíticas da situação internacional contemporânea}

Após exposição sistemática de duas das grandes teorias geopolíticas clássicas, a do poder naval e a do poder terrestre, buscaremos, neste terceiro capítulo, relacioná-las com as grandes tendências geopolíticas e geoestratégicas da situação internacional contemporânea.

\section{Um cenário internacional de transição}

Estamos de acordo com a ideia segundo a qual a atual ordem internacional se caracteriza por uma transição de época. Ao final de um mundo marcado por uma configuração bipolar - característica do período que vai do pós-guerra até o período 1989-1991, em que desaparece o bloco de países polarizados pela União Soviética -, instaurou-se uma breve ordem mundial unipolar (1991-2007) $)^{41}$ e seguida, mais recentemente, de uma situação internacional de transição, marcada pela aceleração de uma tendência à multipolaridade, numa ordem mundial crescentemente marcada pelo policentrismo.

Atualmente, podemos dizer que há uma quase unanimidade entre analistas da situação internacional - pelo menos entre os consultados para efeitos desta Dissertação -, segundo os quais a marca principal do mundo contemporâneo é a ascensão de grandes países em desenvolvimento - sobretudo a China - vis-á-vis com um declínio relativo do hegemon emergido ao fim da bipolaridade, os Estados Unidos.

Esta "quase unanimidade" deve, entretanto, ser matizada pelo fato de que a identificação de um declínio relativo da hegemonia norte-americana e da emergência da multipolaridade, não quer dizer que os Estados Unidos perderão sua condição de

\footnotetext{
${ }^{41}$ Para efeito de apresentação, podemos definir "o fim" da era unipolar como sendo o ano de 2007, com a instauração daquela que é quase unanimemente definida como "a mais grave crise do capitalismo desde 1929". Entretanto, poderíamos localizar sinais ou tendências à multipolarização já no início dos anos 2000.
} 
principal superpotência do mundo "ao virar da esquina" - sobretudo em termos estratégicos, mas mesmo em outros terrenos do poder nacional.

Estamos de acordo com FIORI para quem “não existe nenhuma 'lei' que defina a sucessão obrigatória e a data do fim da supremacia americana”. Afinal,

os EUA não abdicarão voluntariamente do poder global que já conquistaram e não renunciarão à sua expansão contínua, no futuro. Qualquer possibilidade de limitação deste poder só poderá vir do aumento da capacidade conjunta de resistência das novas potências (FIORI, 2010, p. A11).

Pensamos que com a crise internacional eclodida em 2007 - e que resiliente, permanece como marca importante do cenário internacional ao final de 2012 -, intensifica-se um movimento de transição à multipolaridade, ainda que em menor medida no aspecto estratégico, e certamente em maior medida no aspecto político e econômico.

Note-se que a crise mundial trouxe consigo impactos não apenas sobre a ordem econômico-financeira, mas também sobre a ordem política e de forças internacional.

Com a crise, pode resultar a intensificação da tendência intrínseca do sistema internacional à anarquia e a instabilidade, como defendida por ARON (1986) e MORGETHAU (2003).

Ainda na primeira "etapa" da crise, num depoimento dado no início de 2009 ao Comitê de Inteligência do Senado norte-americano sobre as ameaças à segurança nacional de seu país, Dennis C. Blair, Diretor Nacional de Inteligência ${ }^{42}$, impressiona pela franqueza, ao defender que:

The primary near-term security concern of the United States is the global economic crisis and its geopolitical implications. The crisis has been ongoing for over a year, and economists are divided over whether and when we could hit bottom. Some even fear that the recession could further deepen and reach the level of the Great Depression. Of course, all of us recall the dramatic political consequences wrought by the economic turmoil of the 1920s and 1930s in Europe, the instability, and high levels of violent extremism.

${ }^{42}$ BLAIR, Dennis C. Intelligence community annual threat assessment. In: ANNUAL THREAT ASSESSMENT OF THE INTELLIGENCE COMUUNITY FOR THE SENATE SELECT COMMITTEE ON INTELLIGENCE, 2009. Testimonies..., 2009. Disponível em: <http://intelligence.senate.gov/090212/blair.pdf>. Acesso em: 10 jan. 2011. 
Though we do not know its eventual scale, it already looms as the most serious global economic and financial crisis in decades (BLAIR, 2009) ${ }^{43}$.

A preocupação do funcionário norte-americano mostrou-se essencialmente correta: o mundo está cada vez mais instável do ponto de vista geopolítico e estratégicomilitar.

Continuam pairando no ar as consequências geopolíticas da perda de posição relativa da economia norte-americana, europeia e japonesa em relação a novos polos dinâmicos da economia internacional, tais como os BRICS (Brasil, Rússia, Índia, China e África do Sul), e dentre eles, especialmente, a China.

Estas consequências ocorrem, sobretudo, pelo desenvolvimento desigual do capitalismo, exacerbado na crise atual, na qual os países centrais sentem a crise de maneira diferenciada em relação aos grandes países em desenvolvimento - cada vez mais fortalecidos com mercados internos de massa.

Enfim, podemos sintetizar que o mundo atual é marcado por:

a) Perda de posição econômica relativa dos Estados Unidos (ver gráfico a seguir) é o que está na sequencia em relação aos demais países do mundo, que pode também se transformar (em perspectiva, tendencialmente e gradativamente) em perda de hegemonia cultural (ideológica) e mesmo de influência política. Entretanto, não está em questão, pelo menos pelas próximas duas décadas, qualquer superação dos Estados Unidos em matéria de posição estratégica;

b) Ao mesmo tempo, observa-se a emergência de grandes países em desenvolvimento, sobretudo os dotados de grande território e grande população;

\footnotetext{
43 "A principal preocupação de segurança a curto prazo dos Estados Unidos é a crise econômica mundial e suas implicações geopolíticas. A crise está presente há mais de um ano, e os economistas estão divididos sobre se e quando nós poderíamos bater no fundo. Alguns temem ainda que a recessão poderia se aprofundar ainda mais e atingir o nível da Grande Depressão. Claro, todos nós, recordamos das dramaticas consequências políticas forjadas pela crise econômica dos anos 1920 e 1930 na Europa, (com a decorrente) instabilidade e altos níveis de violento extremismo. Embora nós não sabemos sua dimensão final, já aparece como a mais grave crise econômica e financeira global em décadas" (Idem, Ibidem, tradução nossa).
} 
países que tendencialmente podem materializar-se em líder de polos de poder, polarizando suas respectivas regiões do globo.

\section{Evolução da participação no PIB mundial (PPP) 1870-2006}

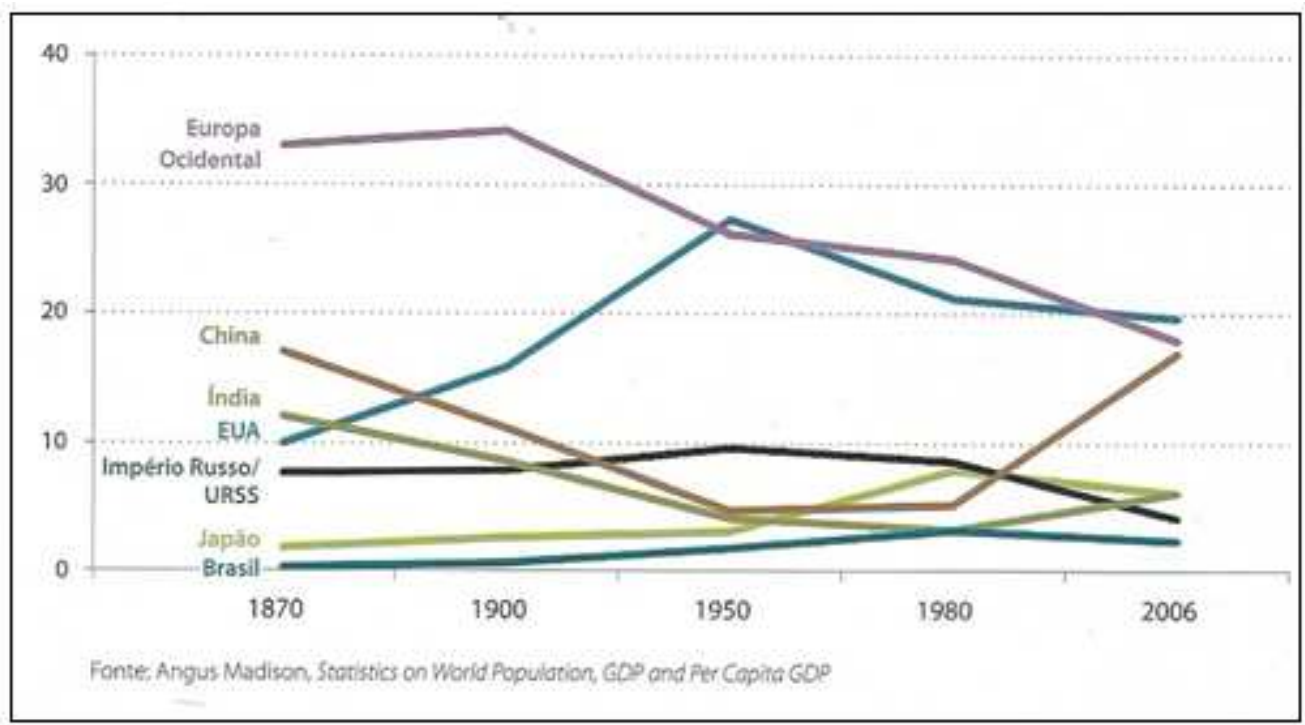

\section{GRÁFICO 01}

Em alguns anos certamente estarão mais nítidos os efeitos da crise do capitalismo de tipo neoliberal sobre a geopolítica e a relação de forças no mundo.

Esta "fase" do capitalismo, iniciada nos anos $1970^{44}$, apresenta seus limites claros com a eclosão da crise, ainda em 2007, a partir da inadimplência nas hipotecas subprime do mercado imobiliário norte-americano; evolui e ganha novo e dramático

\footnotetext{
44"O período iniciado em 1970 que se designa como o do Capitalismo Financeirizado, ou do Capitalismo sob Dominância Financeira ou ainda o "Finance Led Capitalism" já dura mais de 38 anos. Um capitalismo como se verá adiante em que a valorização da riqueza financeira vinha preponderando sobre a produtiva, sem impedi-la, porém expandindo-se a velocidades superiores e produzindo instabilidade econômico-financeira estrutural" (BRAGA, José Carlos. Crise sistêmica da financeirização e a incerteza das mudanças. Estudos Avançados, São Paulo, v. 23, n. 65, p. 89-102, 2009. Disponível em: $<$ http://www.scielo.br/scielo.php?script=sci_arttext\&pid=S0103-40142009000100006>. Acesso em: 01/10/2011
} 
impulso em agosto de 2008, a partir da falência do Banco de Investimentos Lehman Brothers. Desde então, o mundo passa por uma tormenta, cuja expressão maior é uma extraordinária queima de riquezas fictícia e real e um recrudescimento do desemprego e da crise social por todo o mundo. Com isso, desmorona-se o discurso neoliberal, orientação hegemônica do centro do sistema durante décadas e retomam-se ideias até então no index do pensamento econômico, sobretudo as teses desenvolvimentistas e keynesianas.

Com isso, as proposições para a saída da crise incluem novos mecanismos de regulação da movimentação de capitais e um imenso plano de incremento de gastos públicos - uma reedição do New Deal. De importância para nosso debate são as consequências geopolíticas da crise econômica.

Junto com esta questão, o mundo caminha para aquilo que autores como KAGAN (2008) identificam ironicamente como "o retorno da história", em oposição à famosa assertiva do início dos anos 1990 que discorria acerca do "fim da história".

Aqui, podemos dizer que há uma crise da globalização ou "desglobalização", numa demonstração de resiliência do Estado-nação ${ }^{45}$. Por todo o mundo, ocorre um retorno da centralidade do Estado-nação, caindo por terra as utopias da globalização advindas da ordem internacional instaurada no início dos anos 1990, alcunhada de "fim da história", isto é, fim de possibilidades nacionais e da obrigatória "adesão" ao "modelo único" da globalização neoliberal, ocidental e anglo-saxã.

Fenômeno direto desta crise é a intensificação de opções protecionistas e nacionalizações de empresas financeiras e não-financeiras. Nos países desenvolvidos, chegam a ressurgir movimentos xenófobos.

As iniciativas dos países centrais, na busca por sair da crise, em especial, é hoje a principal ameaça à sustentação do ciclo de crescimento econômico, de diminuição da pobreza e, derivado disto, de fortalecimento de um mercado interno em escala regional verificado, ainda que em níveis desiguais, em todos os países da América do Sul na última década e, em geral, nos grandes países em desenvolvimento.

${ }^{45}$ Cf. RICUPERO, Rubens. A resiliência do Estado Nacional diante da globalização. Estudos avançados, São Paulo, vol. 22, n. 62, p. 129-144, 2008. 
No centro do sistema, os Estados Unidos aprovam medidas que retomam cláusulas como o Buy American, que exige compras nacionais de ferro, aço e manufaturados para os investimentos em infraestrutura e o Employ American que impõem restrições à contratação de estrangeiros pelos bancos socorridos pelo governo.

Mais recentemente, tanto os Estados Unidos quanto a União Europeia reforçaram tendências à promoção de "guerra cambial" a partir da desvalorização do dólar e do Euro, deflagradas por volumosas emissões de moeda (impressão de dinheiro). O FED (Federal Reserve, ou Banco Central estadunidense) anuncia emissões de US\$ 40 bilhões ao mês, que somadas à outras iniciativas resultará na emissão de 1 trilhão de dólares ao ano; já o Banco Central Europeu decidiu literalmente imprimir Euros para socorrer países que aderirem ao chamado Fundo de Estabilização ${ }^{46}$.

Por fim, como dissemos no início deste capítulo, há a crise da unipolaridade norte-americana - com a rápida deterioração e o precoce fim da ordem mundial inaugurada nos anos 1990 - e o fortalecimento da tendência à multipolaridade. É certo, em nossa opinião, que os Estados Unidos seguirão como a única superpotência do ponto de vista militar, econômico e cultural-ideológico, todavia por mais um período histórico. Também é certo que há claros sinais de que a tentativa de domínio global que buscou o governo George W. Bush, após o 11 de setembro de 2001, expressa quase que literalmente na chamada Doutrina Bush, chegou a um limite, a um teto.

O governo de Barack Obama foi claramente forçado a tomar medidas - que retomaremos mais a frente -, visando sair do isolamento e relançar sua hegemonia em declínio histórico. Por outro lado, na mesma chave de reforço da tendência à multipolaridade, cresce a tendência à regionalização e à formação de grandes blocos territoriais, com o surgimento de novos polos de poder no mundo ${ }^{47}$.

\footnotetext{
${ }^{46}$ Mais recentemente, cf. Mais um derrame. Folha de São Paulo, São Paulo, 16 set. 2012. Editorial, p. A2. Disponível em: <http://www1.folha.uol.com.br/opiniao/1154137-editorial-maisum-derrame.shtml >. Acesso em: 30/09/2012.

47 Dentre outros exemplos, na América Latina destacam-se instrumentos como o Mercosul, a Unasul (União das Nações Sul-americanas), a CALC (Cúpula América Latina e Caribe) e a ALBA (Alternativa Bolivariana para as Américas); organizações como o G-20 liderado pelo Brasil no âmbito da OMC e o G-5 representando os países em desenvolvimento nos debates com o G-8; o IBAS, fórum trilateral entre Índia, Brasil e África do Sul; a Organização de Cooperação de Xangai na Ásia Central; o mecanismo de consulta trilateral entre China, Î́ndia e Rússia na Ásia; a Cúpula de Chefes de Estado dos BRICS (Brasil, Rússia, Índia, China e África do Sul, na ordem da sigla em inglês); as Cúpulas de Chefes de Estado entre a América do Sul e os Países Árabes (ASPA) e entre a América do Sul e a África.
} 
Em suma, estas novas tendências relacionadas à situação internacional têm enormes repercussões para o pensamento geopolítico brasileiro. Nessa mesma linha de raciocínio, pode-se discorrer, também, de pelo menos outras crises - de natureza cíclica ou estrutural - de grande influência geopolítica, como as crises energética, alimentar e ambiental, presente, em maior ou menor grau, no cenário internacional.

\section{Nuvens carregadas no horizonte do mundo}

Uma importante questão a observar sobre as grandes tendências do cenário internacional é que se é certo que caminhamos para um mundo multipolar, também é certo que um mundo multipolar pode ser tão instável como o mundo unipolar que vivenciamos no imediato pós-guerra fria ou mesmo tão instável quanto à confrontação bipolar que observamos no século XX.

A grande "vantagem" de um sistema multipolar para um país como o Brasil - e para os países em desenvolvimento de modo geral - é um maior equilíbrio de forças; mas estas forças podem expressar interesses contraditórios agudos como em outros formatos de configuração do sistema internacional; afinal, essencialmente e em geral, o sistema internacional é marcado por um comportamento hobbesiano, no sentido de que há uma luta constante por posições, e no qual o interesse nacional determina as ações nacionais.

A despeito das teses oriundas dos países centrais, sobre as "novas ameaças", nos parece que as ameaças de natureza exógena são essencialmente - ou principalmente de natureza estatal, ainda que questões como a pirataria ou o narcotráfico também se configurem em graves problemas de segurança no cenário internacional. Mas aqui, até conceitualmente, é preciso separar dimensões estratégico-militar de ameaças daquelas essencialmente ligadas às complexas tarefas de segurança pública.

É preciso atenção com o discurso, geralmente procedente dos países centrais, sobre as "novas ameaças" ou "guerras de quarta geração". Afinal, se é certo que determinadas ameaças não estatais tem ramificações e modus operandi transnacional, tampouco é certo que estas devem ser tomadas como ameaças centrais. No caso das 
Forças Armadas, instituição em que há forte pressão exógena neste sentido ${ }^{48}$, estas proposições podem ser percebidas como uma tentativa de desviá-las conceitualmente da doutrina de emprego de suas tarefas clássicas vinculadas à proteção da soberania e da integridade nacional, seu objeto primário.

A cooperação no sistema internacional, por sua vez, se apresenta cada vez mais num formato de alianças móveis determinadas por cálculos, cujo pressuposto é (ou pelo menos em geral é) o interesse nacional. Para o Brasil, por exemplo, permanente é seu sistema de alianças com a vizinhança geográfica e cultural: os sul-americanos e a África atlântica e lusófona.

$* * *$

A tendência a multipolaridade observa, entretanto, uma contratendência essencial para nossa percepção de ameaças: observa-se como traço principal do atual cenário internacional, um movimento de contenção dos grandes países em desenvolvimento (destaque novamente), levado a cabo pelas nações centrais, desejosas de manutenção do status quo e de sua ação pretérita.

Muitos exemplos se podem dar neste sentido: a recém-divulgada orientação estratégica norte-americana, com foco na China; as tentativas de cooptação ou neutralização da Índia e da Rússia; e, por aqui, as tentativas de retardar e mesmo dificultar a união sul-americana liderada pelo Brasil - como se deu na recente busca por dividir e enfraquecer o Mercosul, com o episódio do golpe parlamentar no Paraguai; são

\footnotetext{
${ }^{48}$ Ver por exemplo, agenda proposta pelos Estados Unidos - por meio da JID, um instrumento clássico de projeção estratégico-militar desse país em relação a América Latina - na Conferencia de Ministros de Defesa das Américas, realizada no Uruguai, em outubro passado. Estas proposições, recorrentes desde a reunião de Williamsburg (1995), propõe, como muito bem sintetizou o então ministro Jobim, na penúltima reunião, na Bolívia: "Fica subentendida, mas nunca explicitada, uma divisão de trabalho informal: os EUA cuidariam da defesa do hemisfério (segundo seus critérios unilaterais, como ocorreu durante a guerra das Malvinas); os demais países das Américas cuidariam de impedir que as ditas 'novas ameaças' transbordassem em direção ao território norte-americano ou que prejudicassem seus interesses" (Intervenção do então ministro Nelson Jobim na sessão plenária da IX Conferência de Ministros de Defesa das Américas, Santa Cruz de la Sierra, em 22 nov. 2010).
} 
exemplos que expressam esses movimentos de contenção na ascensão de novos polos no sistema internacional.

Os BRICS, aliás, são vistos como uma ameaça aos países centrais, uma vez que a base de sua aliança é o questionamento da ordem internacional estratificada que expressa uma outra correlação de forças no mundo.

A aliança dos BRICS é a principal aliança internacional que exclui a participação dos países centrais - EUA e União Europeia. Logo, torna-se alvo de movimento de contenção.

Como vimos acima, a crise econômica atual, que se manifesta fortemente nos países centrais, que já leva cinco anos e deverá durar outros tantos - se fala inclusive em duas décadas -, tem importantes impactos geopolíticos - até por expressar a aceleração da transição que se vive no mundo, confirmando o declínio relativo do centro e uma ascensão da então chamada "periferia".

Buscando reverter a tendência a multipolaridade, que, portanto, é acelerada com a grave crise econômica mundial, e assim visando prolongar no tempo o status quo, se avolumam iniciativas dos países centrais que buscam impulsionar esta contratendência, indo, como vimos, dos "tsunamis monetários" e desvalorizações competitivas - que buscam exportar a crise aos países em desenvolvimento, contendo seu dinamismo - a iniciativas que visam o asseguramento estável de matérias primas e commodities, enfim, de ativos estratégicos pelo mundo a fora.

Os movimentos de "chutar a escada", como menciona o titulo de um famoso livro, para impedir que outros ascendam ao restrito clube, envolve resistências em reformar as instituições do sistema internacional, como o anacrônico Conselho de Segurança das Nações Unidas ou, ainda, na virulenta reação dos países centrais contra o Acordo de Teerã, realizado com mediação turco-brasileira, que abriria portas para a pacificação das relações com o Irã; o recado é claro: temas estratégicos são de exclusivo manejo do seleto clube dos países com poder nuclear.

Dentre outros, são objeto de diferença entre os países BRICS e as potências centrais a abordagem, por exemplo, em relação ao Irã - assim como foi em $2011 \mathrm{em}$ relação a Líbia, com a abstenção dos quatro BRICS no Conselho de Segurança das 
Nações Unidas ${ }^{49}$ e hoje há importantes diferenças em relação a crise na Síria, onde os dois BRICS que são membros permanentes (Rússia e China) veem vetando sistematicamente tentativas dos países ocidentais centrais em reproduzir o modus operandi testado na Líbia em 2011.

Afinal, as nações centrais tem recorrido até mesmo à guerra - feita sob pretextos humanitários e após a devida "catequização" da opinião pública ocidental - nesse movimento pela manutenção de sua hegemonia e contenção da ascensão dos grandes países e blocos de países em desenvolvimento.

Mais recentemente, reabilitam a tese da "responsabilidade de proteger" (RtoP ou $R 2 P$, na sigla em inglês), ensaiada no governo Clinton e assumida na plenitude pelo governo de Obama junto com os europeus.

Esta tese institui junto ao Conselho de Segurança das Nações Unidas a possibilidade da "comunidade internacional", isto é, dos países centrais, tomarem partido em contextos de guerra civil ou crises humanitárias, ambientais, etc., depondo governos não alinhados ao estabilishment.

Trata-se da política também conhecida como "regime change" (mudanças de regime), promovidas pelas potências centrais. Uma subversão completa do conceito clássico de soberania, cujo respeito é a base do sistema internacional.

\section{Para melhor compreender a nova geoestratégica da contenção}

Retomemos aqui a atualidade das teorias do poder terrestre e do poder naval.

O velho Mackinder ressurge no cenário de disputas pela hegemonia em curso no heartland (terra-coração) que, podemos dizer, se localiza em sua plenitude contemporânea, na área da Eurásia, localizada a partir de quatro pontos cardeais: a leste, a "porta dos fundos" da China colada ao Afeganistão (província de Xijiang); ao sul, a Índia; a norte, a Rússia; e a oeste, a área contigua ao Irã.

${ }^{49}$ Em 2011, além dos dois BRICS membros permanentes do CS (China e Rússia), Brasil e Índia exerciam mandatos temporários. 
Nesta região terrestre, núcleo da grande massa territorial da terra, duelam nações poderosas, dentre elas pelo menos quatro ou cinco nações nuclearmente armadas. Não se trata aqui, pois, da reabilitação do velho Mackinder?

De um lado, toma cada vez mais feições de aliança estratégica, a Organização de Cooperação de Xangai, que realiza regulares exercícios conjuntos na Ásia Central. De outro, a forte presença norte-americana e das demais forças da OTAN no Afeganistão e no Paquistão, ademais de incursões pontuais por outros países anteriormente sob influência da então URSS, suscitam temores justificados de que os países ocidentais notadamente os EUA - buscariam obter uma posição permanente na região.

Por outro lado, as crescentes tensões no mar da China em torno de reivindicações territoriais e anúncios como o que afirma que os "EUA terão maioria de frota de guerra no Pacífico até 2020”, inclusive seis porta-aviões, no total de $60 \%$ de suas embarcações de guerra ${ }^{50}$, nos fazem retornar aos velhos preceitos estratégicos do velho almirante Mahan. Em 2012, Leon Penetta, chefe do Pentágono, fez três longas tournées a esta região, visando obter novos aliados e posicionar suas tropas para o que se anuncia como uma longa contenda.

Ainda neste contexto, é importante ouvir o que diz Michael Klare, segundo quem "ao dominarem as águas chinesas, os Estados Unidos poderiam exercer um poder coercitivo latente sobre Pequim e outros estados da região, como fazia antes a Marinha britânica. Os conselheiros do Pentágono clamavam por tal política havia muito tempo, defendendo que a vantagem singular dos Estados Unidos residia em sua capacidade de controlar as principais vias marítimas mundiais, um privilegio que nenhuma outra nação tem"51. Tese mais mahaniana impossível.

Neste mesmo artigo, aparece a declaração de William J. Burns, para quem "a ascensão da China não apenas remodelou as cidades e a economia asiática: ela

\footnotetext{
${ }^{50}$ EUA terão maioria da frota de guerra no Pacífico até 2020. Folha de São Paulo, São Paulo, 03 jun. 2012. Primeiro Caderno, p. A17. Disponível em: <http://www1.folha.uol.com.br/fsp/mundo/46642-eua-terao-maioria-da-frota-de-guerra-nopacifico-ate-2020.shtml>. Acesso em: dia mês abreviado ano.
}

51 "KLARE, Michael. Pentágono se volta para o Pacífico. Le Monde Diplomatique, 07 mar. 2012. p. 04 e 05. Disponível em: <http://www.diplomatique.org.br/artigo.php?id=1117>. Acesso em: dia mês abreviado ano. 
redesenhou o mapa geoestratégico (...) para citar apenas um exemplo, metade das cargas mercantis passa agora pelo Mar da China meridional”.

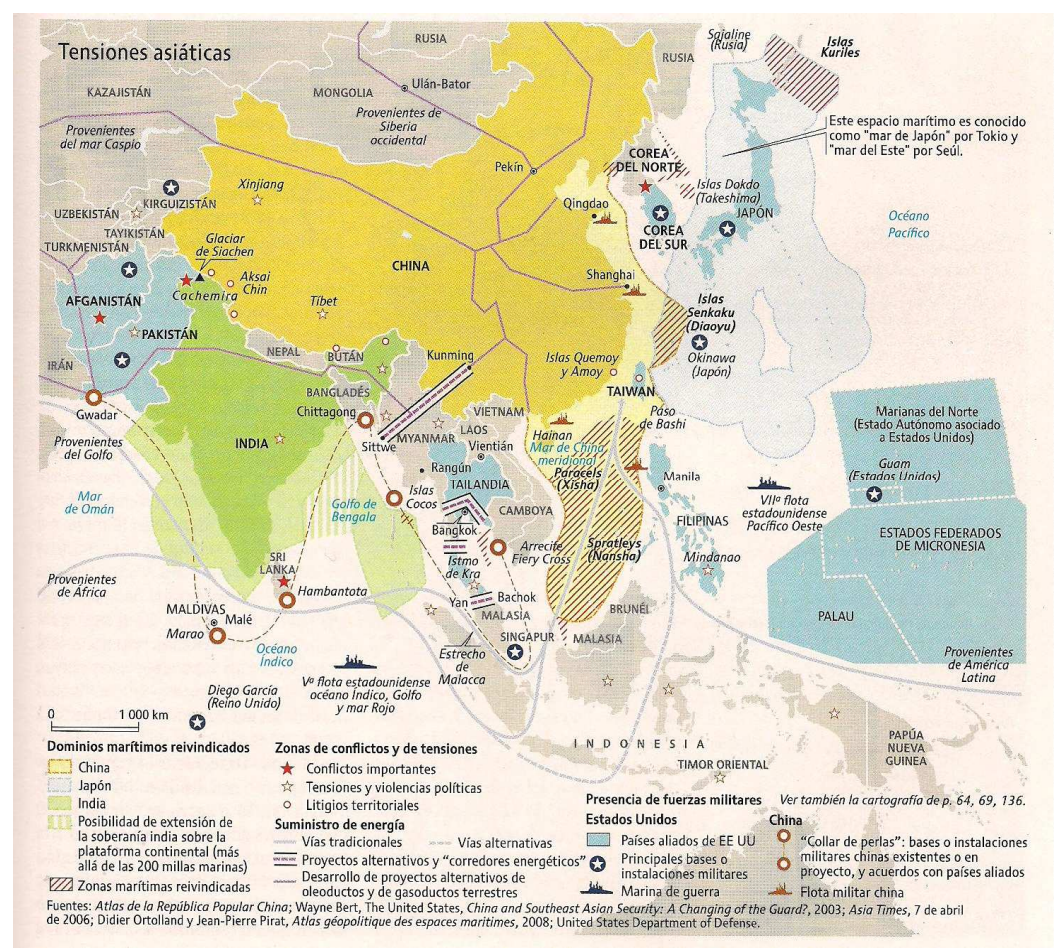

MAPA 09 Fonte: El Atlas Geopolítico 2010, p.53

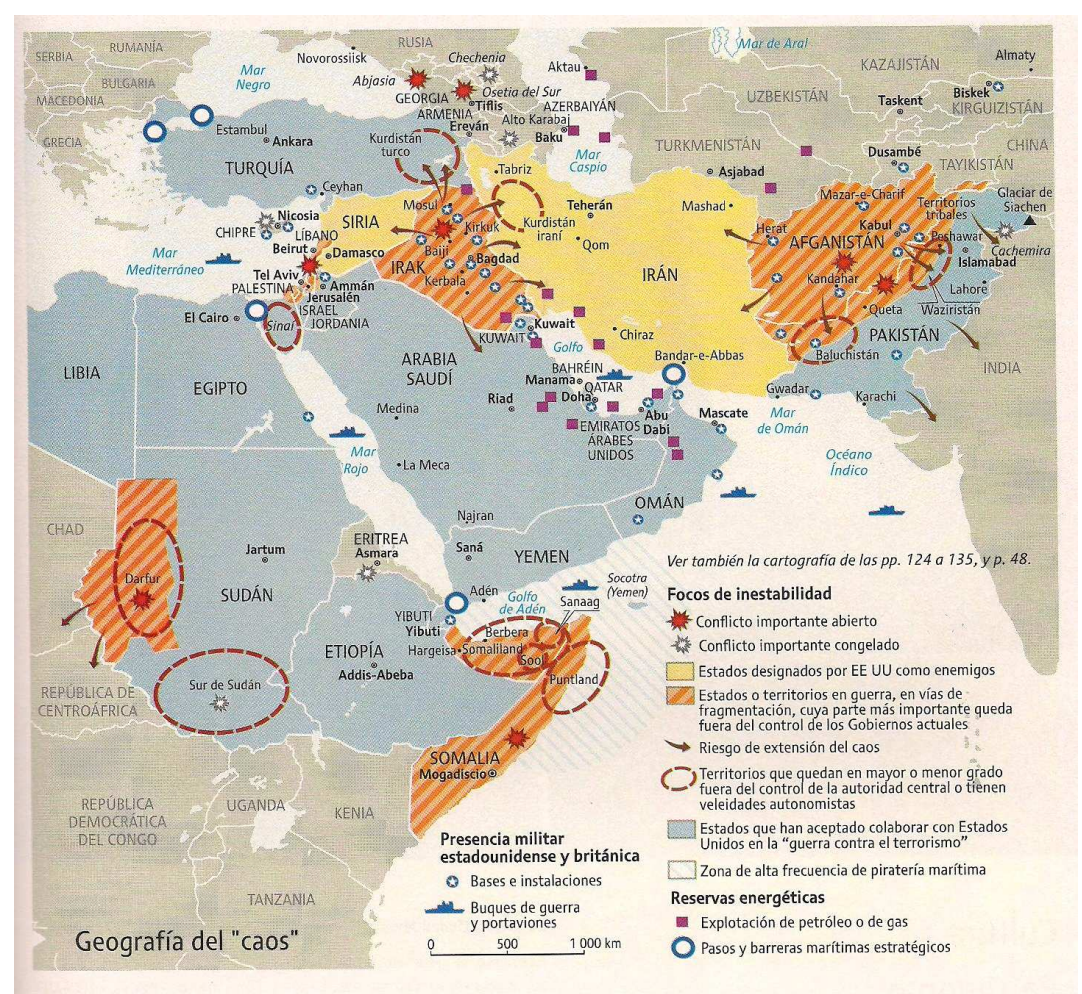


MAPA 10 Fonte: El Atlas Geopolítico 2010, p.59

\section{As redefinições no cenário geopolítico e geoestratégico}

No governo Obama vem ocorrendo importantes reorientações doutrinárias que tem deixado mais clara a observância de preceitos geopolíticos e geoestratégicos. Referimo-nos especialmente a dois documentos recentes: primeiro, a Estratégia de Segurança Nacional, publicada em maio de 2010, e mais recentemente, documento com o sugestivo nome de "Sustentando a liderança global dos EUA: prioridades para a defesa do século 21" (no original, "Sustaining U.S. global leadership: priorities for 21st century defense").

O sentido geral desta reorientação é o curso, enquanto política de Estado, de um movimento geral cujo sentido é buscar recompor a hegemonia absoluta dos Estados Unidos.

Isso fica claro, por exemplo, no discurso de Obama que ocorreu na Academia Militar de West Point, em 2010, seguido ao lançamento da nova Estratégia de Segurança Nacional dos Estados Unidos ${ }^{52}$, que substitui a anterior, do governo Bush. Nele, o governo Obama propôs "revitalizar o poder econômico, moral e inovador" dos EUA visando "manter sua liderança mundial" - em termos parecidos em que se pronunciaria depois no discurso sobre o Estado da União. Na introdução à Estratégia, diz Obama, que "num novo século cuja trajetória é incerta, os Estados Unidos está pronto para ser o líder uma vez mais".

Literalmente, afirma o documento que: “[...] nossa estratégia de segurança nacional está focada em renovar a liderança estadunidense para que possamos impulsionar com maior eficácia nossos interesses no século XXI” (tradução livre).

A Estratégia de Segurança Nacional de 2010 de Obama é explícita, ainda que não tanto quanto o famoso draft do Defense Planning Guidance (DPG), de 1992, ainda no governo de Bush pai, escrito pelos falcões da era Bush filho, Lewis Libby, Paul Wolfowitz e Dick Cheney, que preconizava, sem meias palavras, que os Estados Unidos

\footnotetext{
$52 \quad$ Disponível <http://www.whitehouse.gov/sites/default/files/rss_viewer/national_security_strategy.pdf>. Acesso em: 15 jan. 2011.
} em: 
deveriam impedir por qualquer meio o aparecimento de potências que rivalizassem com seu domínio planetário.

Também guarda grande importância, o segundo documento, anunciado no início deste ano (janeiro), como dissemos, denominado "Sustentando a liderança global dos EUA: prioridades para a defesa do século 21".

Neste documento, está o que analistas, como um ex-embaixador brasileiro naquele país, analisaram como "a mais profunda mudança estratégica na sua política externa e de defesa desde 2002, quando George Bush, sob impacto do atentado de 11 de setembro, radicalizou a ação no exterior" ${ }^{, 53}$.

Estes movimentos de redesenho da estratégia de segurança nacional norteamericana são fruto, segundo disse no Rio de Janeiro, o secretário de Defesa, Leon Penetta, de "um esforço para projetar uma estratégia para as forças de Defesa dos Estados Unidos para o futuro" ${ }^{, 54}$.

Neste último documento, afirma-se textualmente, que os Estados Unidos se voltam "àqueles que buscam impedir a projeção de poder dos EUA" e reconhece "a longo prazo, a emergência da China como uma potência regional que poderá afetar a economia e a segurança dos EUA de diversas formas", propondo assim, "um reequilíbrio voltado para a Ásia - Pacifico",55.

Junto a esta ofensiva estratégico-militar, surgiu recentemente uma ofensiva econômica - com impactos inclusive sobre a integração sul-americana, como veremos mais a frente -, representada pelo lançamento da chamada Parceria Trans-Pacífica, sem a participação da China.

Trata-se de envolver países da área do Mar do sul da China, declarado área de interesse dos EUA, onde, lembrando novamente das lições do velho almirante Mahan, se move quase metade do comércio mundial, mais de US\$ 5,3 trilhões ${ }^{56}$.

\footnotetext{
${ }^{53}$ BARBOSA, Rubens. A resposta dos EUA. O Globo, Rio de Janeiro, 28 ago. 2012. p. 17.

${ }^{54}$ Informação fornecida por Leon Penetta na Escola Superior de Guerra (ESG). Disponível em: <www.defesanet.com.br>. Acesso em: 10/10/2012.

${ }^{55}$ Cf. "Sustaining U.S. global leadership: priorities for 21st century defense". Disponível em: <http://www.defense.gov/news/Defense_Strategic_Guidance.pdf>. Acesso em: 14/10/2012

${ }^{56}$ BARBOSA, Rubens, op.cit., loc. cit.
} 


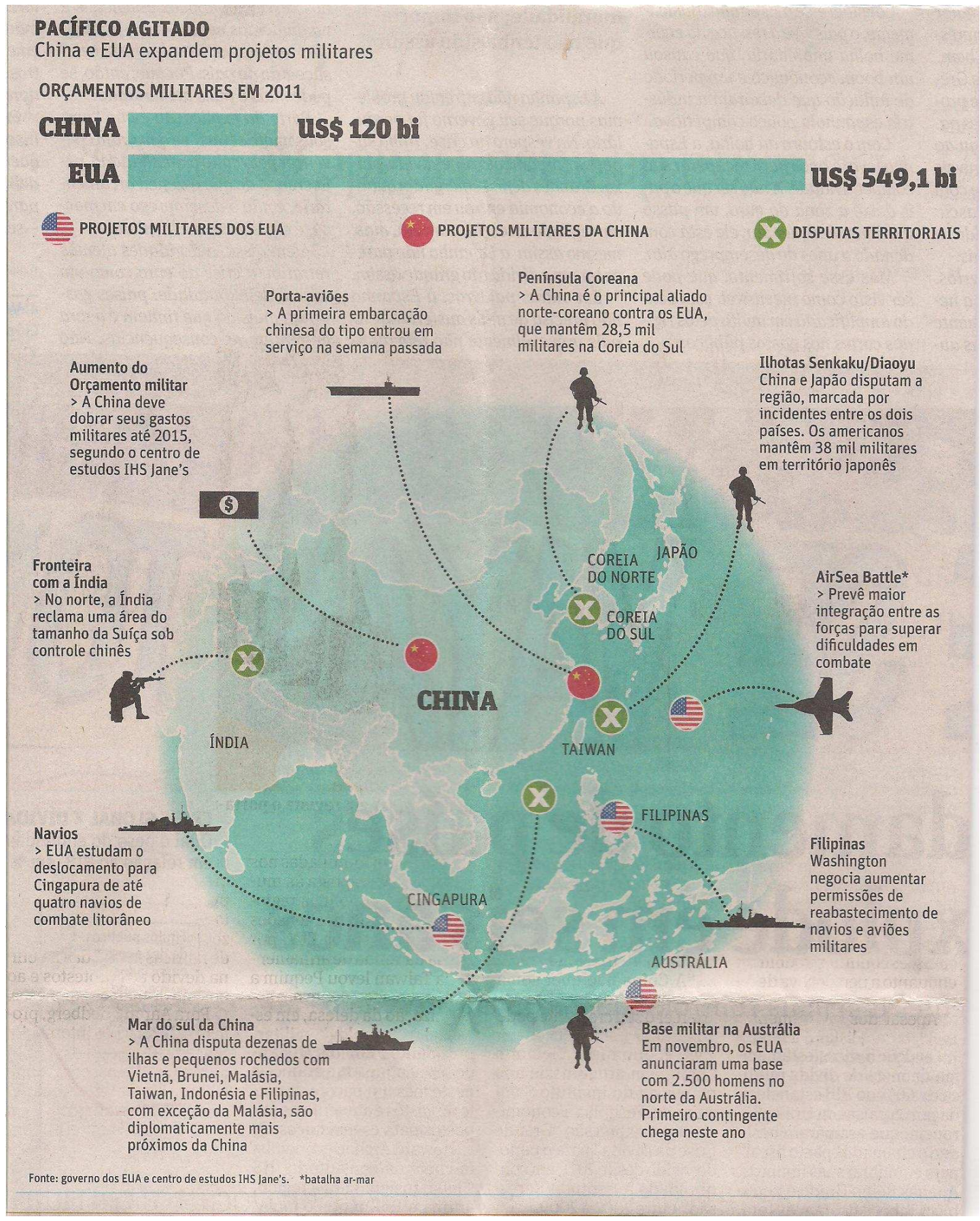

MAPA 11. Fonte: Folha de São Paulo, mundo 2, p. 3, 29/09/2012

O fato é que diante da diminuição do poder relativo da potência hegemônica fato admitido na Estratégia e em diversos outros discursos e pronunciamentos oficiais , se buscam medidas para reverter esta tendência - definidas a partir de amplo debate ocorrido no último período no estabilishment norte-americano - parte dele vazado às 
revistas especializadas, como a Foreign Affairs dentre outras, e em relatórios e publicações de think-thanks.

$\mathrm{Na}$ busca por reverter essa tendência, ocorre uma reabilitação da geopolítica clássica, como os já citados, e nesta, retoma-se com centralidade o conceito basilar da guerra fria, que em grande medida foi responsável pela vitória norte-americana no enfrentamento com a União Soviética: a chamada Doutrina da Contenção, que defendia a construção de um "cordão sanitário" - a partir de um conjunto de Estados-tampão - ao redor da União Soviética, visando conter sua expansão.

A Doutrina da Contenção tem suas raízes no próprio pensamento mackinderiano, no alerta que este autor faz, no que diz respeito à possibilidade de uma aliança russo-germana dominar o heartland e assim, a ilha-mundo. Ou ainda, na ameaça que Mackinder identifica no chamado "perigo amarelo" chinês.

A proposta de contenção dá um importante salto com a teoria geopolítica proposta por Nicholar Spykman, especialmente com a chamada teoria do rimland ou das fimbrias.

Entretanto, a chamada Doutrina da Contenção é formalmente incorporada à visão geopolítica e geoestratégica estadunidense a partir de formulações sistemáticas que seriam apresentadas pelo então embaixador desse país em Moscou, George Kennan, quem inicialmente sistematizou suas posições num despacho diplomático, enviado em 1946 ao Departamento de Estado, que viria a ser conhecido como "The long telegram" (O longo telegrama).

Estas ideias apareceriam pouco depois num artigo escrito para a Foreign Affairs, de julho de 1947, cuja autoria está relacionada à um certo Sr. X (pseudônimo de Kennan, que como embaixador em Moscou, teria dificuldades de assinar artigo com teses tão contundentes).

No artigo, denominado "Motivações da conduta soviética", Kennan defende a implementação de uma política que viria a se converter na política de Estado norteamericana, que por meio de um prolongado desgaste seria em grande parte responsável pela vitoria de Washington no enfretamento com Moscou.

Argumenta Kennan que:

[...] o principal elemento de qualquer política dos Estados Unidos com relação à União Soviética deve ser uma contenção das tendências expansionistas russas; essa contenção deve ser prevista a largo prazo, 
paciente, mas também firme e vigilante. Contudo, é importante observar que essa política não tem nada a ver com histrionismo exterior - com ameaças, bulhas ou gestos supérfluos de 'dureza' (DALLIN, 1964, p. 23).

Assim, se estabeleciam as bases de uma longa política de desgaste do contendor soviético, que viria a desgastar esse país, política, econômica e militarmente ao longo de três ou quatro décadas.

O fato é que o problema de impedir o surgimento ou conter a emergência de novas potências que passam a rivalizar, de fato ou tendencialmente com sua hegemonia, é objetivo geopolítico de Estado, invariável e permanente dos Estados Unidos, desde que esse país lançou sua “doutrina” de política externa, com o presidente Monroe.

Mais recentemente, podemos retomar estas teses em documentos que aparecem no imediato após termino da guerra fria $^{57} \mathrm{e}$, agora, mais recentemente, nos dois documentos citados, de 2010 e de 2012.

\section{Grandes traços do cenário geopolítico}

Assim, como vimos, os Estados Unidos miram a China como seu grande contendor. $\mathrm{O}$ perigo amarelo, do qual Mackinder se referiu, se materializa no imaginário (e na realidade) da visão geopolítica e geoestratégica norte-americana.

Por um lado, observa-se um crescente deslocamento do poder político e econômico da periferia ocidental para a periferia oriental da imensa massa Eurasiana. Prostrada, a União Europeia, frágil na coesão econômica e dividida quanto a seus objetivos, vai compartilhando e mesmo dando lugar a China como ator que em teoria teria alguma condição de rivalizar com os Estados Unidos. Por outro lado, e parte do mesmo movimento, há uma mudança crescente na centralidade oceânica - do Atlântico norte para o Pacifico.

A observação do cenário geopolítico mundial contemporâneo nos permite afirmar que, dando razão à Mahan e Mackinder, nas duas áreas que se caracterizam

${ }^{57}$ Por exemplo, em 1992, no "Draft defense planning guidance", podemos verificar a seguinte ideia: "Our first objective is to prevent the reemergence of a new rival'. 
como pontos centrais de tensão estratégica, está em questão a luta do poder terrestre e do poder naval.

A primeira área de tensão é a vasta zona que vai da província chinesa de Xinjiang até o norte da África, passando por regiões como o Afeganistão e o Paquistão, o Irã, o Iraque e a região do Golfo Pérsico, e toda a área contígua Líbano-Síria-IsraelEgito-Líbia. Nesta vasta área, trava-se uma espécie de grande jogo moderno. Tentando, sem sucesso, estabilizar o Afeganistão e o Iraque, as potências ocidentais (EUA e Europa) passam a enfrentar um terceiro front, indesejado num primeiro momento, que é a eclosão de revoltas populares em um conjunto de países árabes.

Outra área de tensão, como vimos, esta pelos oceanos, é a região dos mares orientais, sobretudo o Mar da China, o ponto crítico de passagem (estreito de Malaca) e a presença avassaladora dos Estados Unidos em seus protetorados na região: Japão, Coréia do Sul - a constante tensão na península coreana - e mesmo Taiwan, militarmente equipado por Washington.

Os Estados Unidos mantém quase que intacta sua política, que vem do período da guerra fria, de contenção do domínio euro-asiático a partir da presença nos rimland ou fimbrias: nos últimos anos a Europa oriental aderiu em massa a OTAN, a invasão no Afeganistão e as bases norte-americanas na Ásia Central, e a manutenção dos protetorados na Ásia oriental - Japão, Coréia do Sul e em alguma medida, Taiwan. Estes três exemplos são demonstração da persistência da estratégia de contenção que se formulou por ocasião do curto período em que aliadas, URSS e China, controlavam o grosso da massa euro-asiática (ver mapa a seguir).

Essa, aliás, é a percepção de FIORI. Para ele, no cenário atual, os Estados Unidos podem:

manter a estratégia clássica, definida por Alfred Mackinder, no final do século 19. A mesma estratégia que foi seguida pela Grã-Bretanha, durante o século 19, e que foi mantida pelos EUA, depois do fim da Segunda Guerra Mundial: cercar a Rússia e impedir de todas as maneiras a sua aproximação da Alemanha. Esta foi de novo a opção dos EUA, depois do fim da guerra fria, com a incorporação militar da Europa Central à OTAN e o estabelecimento de bases militares americanas nos territórios da Ásia Central, como forma de apoio às guerras do Iraque e do Afeganistão (FIORI, 2011). 


\section{o bloco sino-soviético e as três frentes estratégicas centrais}

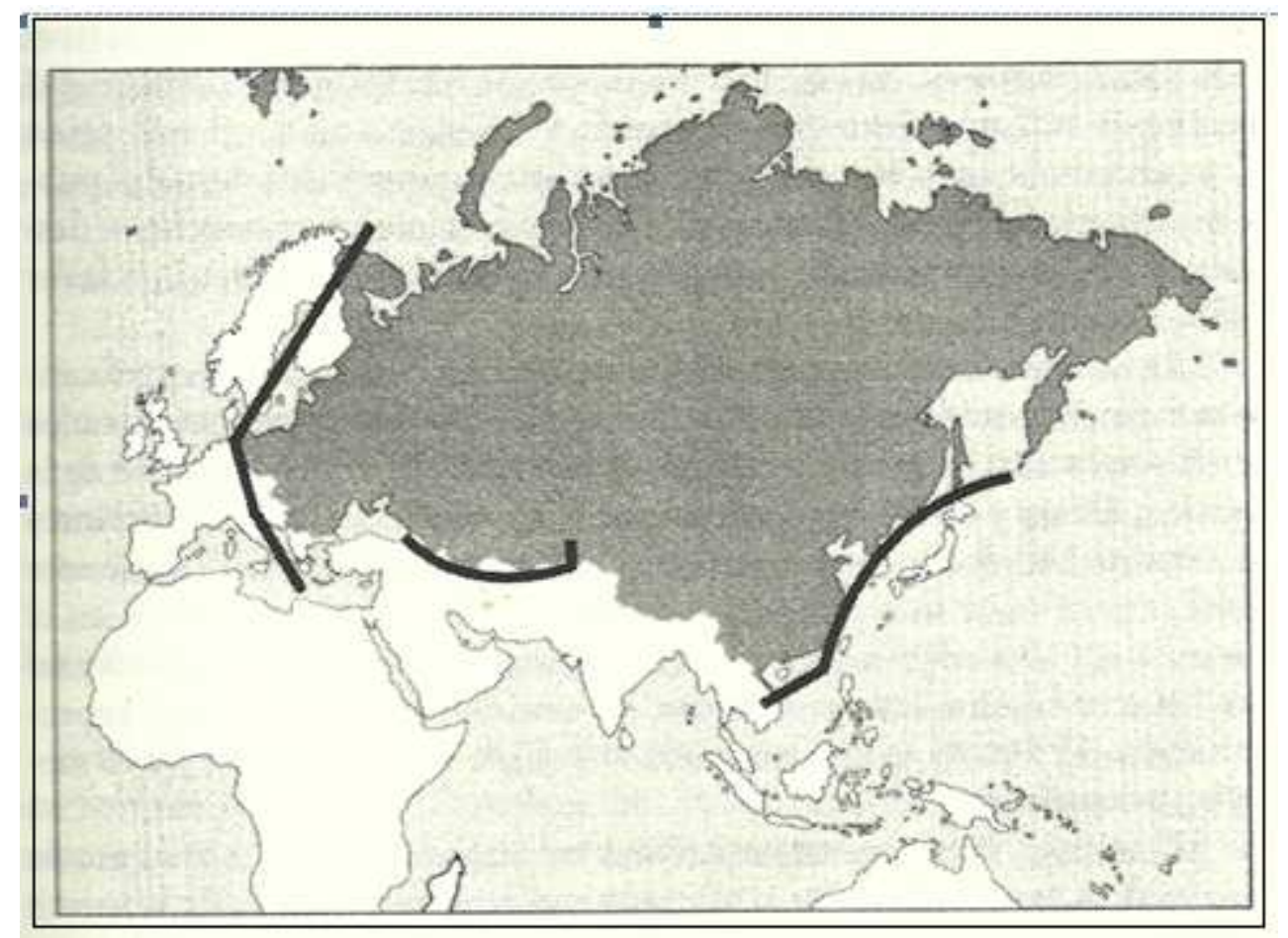

MAPA 12. Fonte: BRZEZINSKI, 1998:17

É um dado geopolítico expressivo da atual realidade, a flagrante perda de poder político da Europa, fruto de sua situação geral de "divisão e desorientação" "58. A última novidade é o aprofundamento da fratura entre os três atores geopolíticos principais:

- A Alemanha, unificada, passa a ter cada vez mais autonomia, com relativa recuperação de seus interesses nacionais - a despeito de continuar ocupada por tropas estadunidenses até hoje, duas décadas depois do fim da União Soviética;

${ }^{58}$ FIORI, José Luís. Guerra na África é nova corrida imperialista, diz Fiori. Entrevista à Folha.com, São Paulo, 04 abr. 2011. Disponível em: <http://www1.folha.uol.com.br/mundo/896777-guerra-na-africa-e-nova-corrida-imperialista-dizespecialista.shtml>. Acesso em: 12/12/2011 
- A França, que segue proliferadora (grande comerciante de armas) no anseio de angariar aliados, e no caso líbio e sírio, voltou a mostrar protagonismo próprio, como há muito não se via;

- A Grã-Bretanha, fortaleza econômica - a despeito da grande recessão que virá do draconiano ajuste fiscal imposto por David Cameron -, segue inabalável na sua crença atlantista, sem maior relevância no contexto europeu.

O impacto da crise econômica mundial na Europa, tem pesadas consequências para a periferia desse continente dentre eles, Portugal, faz reforçar o papel da Alemanha como polo dinâmico europeu. Para FIORI,

no curto prazo, se impôs a posição alemã, favorável a um ajuste fiscal draconiano de todos os países incorporados à zona do euro (...afinal) se os pequenos estados europeus não aceitarem a condição de províncias fiscais da Alemanha, o sistema monetário europeu e o próprio euro estão com seus dias contados (FIORI, 2011).

$* * *$

Os Estados Unidos, nos dias atuais (administração Obama), parecem se defrontar com duas grandes questões tidas como de segurança nacional:

O primeiro é o que podemos chamar de dilema de Huntington - em alusão ao célebre estudo que defendia que os Estados Unidos eram ameaçados por bárbaros que poderiam pôr em marcha um Choque de Civilização. O dilema, pois, é que a busca norte-americana - e mais amplamente, ocidental - de impor seu modelo de democracia e mesmo de civilização a todo o globo - e mais explicitamente a vasta área de tensão euro-asiática a que nos referimos acima - tem gerado toda sorte de tensões e ressentimentos, que cedo ou tarde se voltarão novamente contra os Estados Unidos, a exemplo do indesejado 11 de setembro de 2001.

Este dilema gera uma perda irreparável para os intentos estadunidense de estender no tempo sua hegemonia planetária; trata-se da diminuição relativa de sua outrora vasta influencia cultural/ideológica, seu soft power - do "vago, mas significativo atrativo cultural do American way of life", de que menciona BRZEZINSKI, (1998, p. 19). 
Uma segunda grande questão é o que FIORI (2011) denominou como guerra de posições entre os Estados Unidos e os BRICS.

Os Estados Unidos atuam no sentido de bloquear países que tendencialmente podem materializar-se em líder de polos de poder, polarizando suas respectivas regiões do globo e, assim, converter-se em rivais do próprio poder norte-americano.

$* * *$

Estamos de acordo com o que assinala FIORI, a respeito de que:

terminou definitivamente o tempo dos 'pequenos países' conquistadores. $\mathrm{O}$ futuro do sistema mundial envolverá - daqui para frente -uma espécie de 'guerra de posições' permanente entre grandes 'países continentais', como é o caso pioneiro dos EUA, e agora é também, o caso da China, Rússia, Índia e Brasil". Ainda que, "nesta disputa, os EUA já ocupam o epicentro do sistema mundial (FIORI, 2010).

Assim, a situação internacional contemporânea, bem como suas tendências para o próximo período se caracterizam por uma condição em que "todos competem com todos, e todas as alianças são possíveis, em função dos objetivos estratégicos do país, e do seu projeto de mudança do sistema mundial". Assim, "do ponto de vista geopolítico, o sistema mundial ainda segue vivendo uma difícil transição - depois do fim da Guerra Fria - de volta ao seu padrão de funcionamento original”.

Voltemos à estratégia de contenção dos BRICS. Ao que parece, a estratégia de conter os grandes países em desenvolvimento é muito mais sutil que a verificada no primeiro caso - dilema de Huntington -, em que a mão pesada do imperialismo se faz sentir.

Aqui, busca-se desenvolver uma tática de neutralização ou, idealmente, de cooptação.

No caso da relação com a China, os Estados Unidos oscila entre cooperação e tensão, com ênfase na segunda.

Os Estados Unidos, certamente, são temerosos quanto a movimentação comum dos três grandes poderes asiáticos: China, Rússia e Índia, que ademais de manterem um mecanismo permanente de consulta trilateral, trabalham, sobretudo, os dois primeiros, 
na pacificação da Ásia Central por meio do mecanismo conhecido como Organização de Cooperação de Xangai, que, aliás, possui declarados propósitos estratégicos-militares.

Os Estados Unidos trabalham pela divisão de seus potenciais rivais

Para isso, contam com a "vantagem" de que, por certo, os BRICS estão longe de serem homogêneos, tanto no que diz respeito a suas características nacionais como em seus difusos, ora convergentes, ora contraditórios interesses nacionais.

No atual contexto histórico, entretanto, há uma grande unidade entre eles: a centralidade da questão nacional. Em diferentes graus, há prevalência de projetos nacionais ou esboços deles - isso vai da República Popular da China, dirigida por uma elite que tem nítido o projeto de país, até países como Rússia e Brasil que, após terem logrado uma relativa industrialização, podem ser sufocados pelo modelo primárioexportador. Ainda assim, parece-nos que há uma crescente unidade de propósitos.

Mas há também importantes diferenças. Uma das principais parece ser a diferença em termos do que LACOSTE (2008:150) denominou como "forte unidade nacional" ao referir-se ao Brasil. A esta questão retomaremos com mais afinco no Capítulo IV.

Referimos-nos a distinção - em termos de vantagem geopolítica - entre Estados nacionais compostos por diversas etnias - e assim, sujeito a profundas fraturas étnicoraciais - daqueles dotados de uma maior coesão nacional e homogeneidade - num contexto em que a potência hegemônica estimulará divisões entre seus principais contendores e mesmo no interior de cada um deles. Veja o exemplo da China no mapa a seguir: 


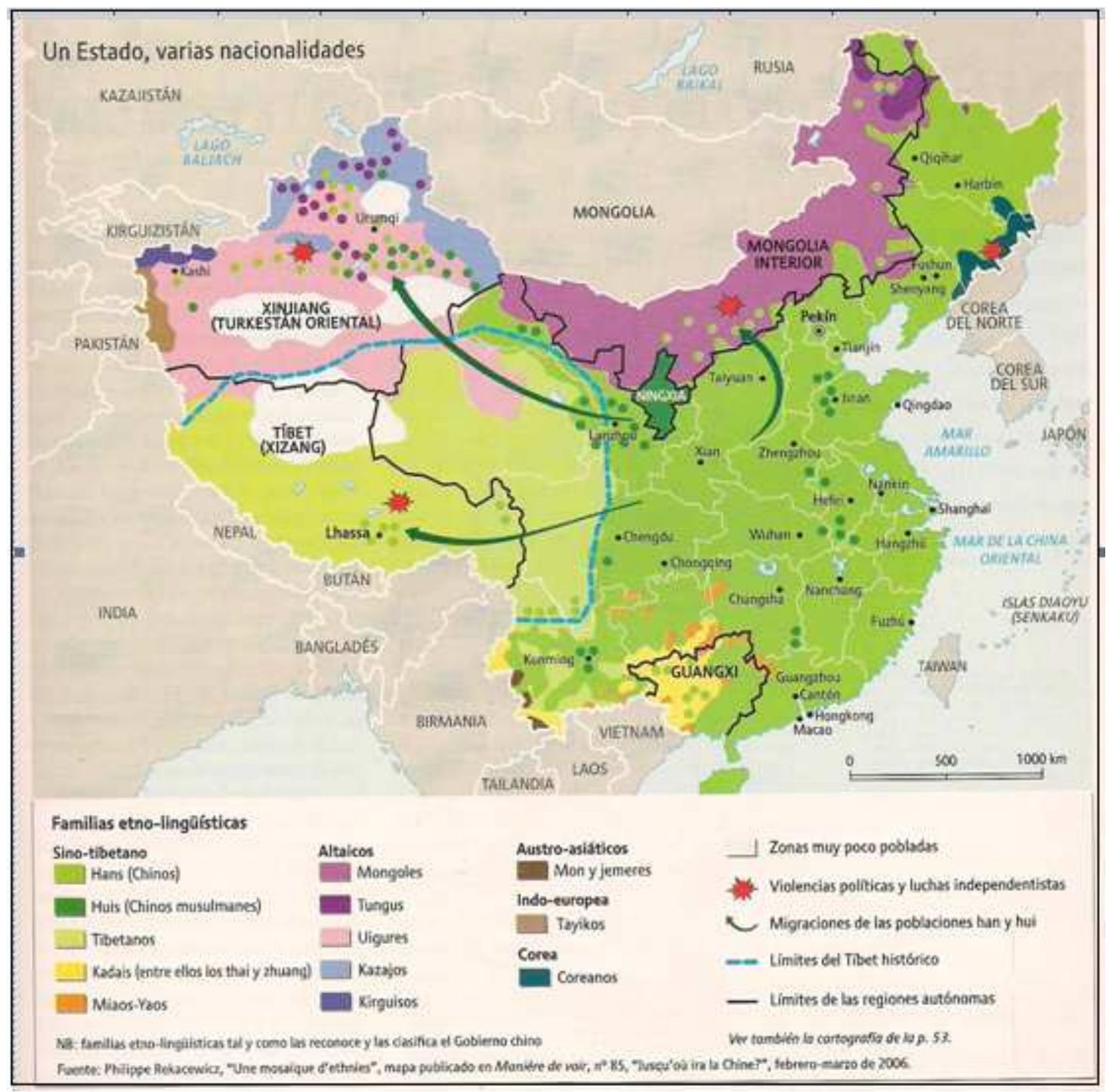

MAPA 13. Fonte: El Atlas Geopolítico 2010, p. 141

Há outras relevantes vantagens/desvantagens geopolíticas que diferenciam os BRICS. Dentre elas é possível citar características físicas e territoriais, tais como tamanho, característica e disposição do território. Outro exemplo, como dissemos, é o tamanho da população e sua unidade nacional. Uma terceira pode ser chamada de unidade de propósitos (vontade nacional). Finalmente, são distintas- e por isso, geram diferentes potencialidades futuras -, a diferença de meios para a materialização da prosperidade nacional (projeto nacional). Voltaremos a estas questões no Capítulo IV e nas Conclusões.

Uma característica comum aos grandes contendores do império norte-americano é o fato de todos os BRICS terem em comum a busca de certa hegemonia ou liderança 
regional. Podemos dizer que se trata da busca de cada um dos grandes países em desenvolvimento, de polarizar uma região, visando maior força para atuar no sistema internacional, buscando colocar a seu favor aspectos que mais the digam respeito no grande jogo de forças globais. Nesse sentido, dados da atuação regional dos países BRICS apontam que:

- A China sustenta altos déficits comerciais com seus vizinhos, beneficiando-os com relação aos países centrais ocorre o inverso, isto é, altos superávits. A China oferece um conjunto de tarifas preferenciais à chamada "Asean+10";

No entanto, por outro lado, a China possui inúmeros problemas de tensões em suas fronteiras, sejam as marítimas (Mar da China, Taiwan, disputas de ilhas com Japão e Vietnã), relacionada à Coréia do Norte (península coreana) e nas suas fronteiras ocidentais: tensões étnico-territoriais relacionados à muçulmanos em Xinjiang e aos tibetanos no Ocidente;

- O problema russo, com o desmoronamento da União Soviética - chamada por Vladimir Putin de grande catástrofe geopolítica do século XX -, resulta em perda líquida de território e um longo período de decadência nacional. Por outro lado, à base industrial e de desenvolvimento científico e tecnológico da era soviética, permite à projeção/elaboração de um projeto nacional - a exemplo do Brasil, como dissemos, a Rússia também se defronta com os riscos inerentes ao modelo primário-exportador;

A Rússia busca influenciar seu entorno, seja pela solidariedade étnica com russos na Ucrânia e Belarus, seja pela presença na Ásia Central. A iniciativa mais destacada, feita em sociedade com a China, é a constituição da Organização de Cooperação de Xangai; 
- A Índia, espremida entre Paquistão e China, tem problemas étnicos relevantes (como, por exemplo, na Caxemira) e uma sociedade fraturada, seja em castas ou etnias;

Por outro lado é potência atômica - não por acaso os Estados Unidos tem política especial para o país, seja no governo Bush ou no governo Obama. Além disso, a Índia tem formulação estratégica relevante em especial no que diz respeito aos assuntos do Oceano Índico;

- A África do Sul é a sociedade e o Estado mais desenvolvido do continente africano. Tem fortes interesses regionais, mas disputa (desfavoravelmente) com outras potências extrarregionais (EUA e UE, China, Índia e Brasil, pela ordem -, a despeito do alarmismo desinteressado em relação à expansão chinesa).

O conjunto RIC (Rússia, Índia e China), as três grandes potências do heartland eura-asiático, tem, entre si, o dilema da cooperação versus conflito. Tendem, hoje, mais a cooperação, inclusive (e, sobretudo) pela presença de um incomodo ator extrarregional muito poderoso (EUA).

Também outros países importantes em desenvolvimento buscam afirmar um projeto nacional próprio; dentre eles, destaca-se na região da Eurásia, o Irã e, em menor medida, a Turquia.

Assim podemos situar os grandes traços geopolíticos e geoestratégicos da situação internacional contemporânea. Ter claro esta evolução, suas principais tendências, é essencial para o que trataremos ao final deste trabalho: as repercussões destes movimentos para a atualização da "grande estratégia brasileira". 


\section{CAPÍtulo IV}

\section{Escola geopolítica brasileira: notas retrospectivas e contemporâneas}

Não existe algo como uma ciência geral da geopolítica, que possa ser subscrita por todas as organizações estatais. Há tantas geopolíticas quantos os sistemas estatais em luta sob condições geográficas, as quais, no caso do poder marítimo e do poder terrestre são fundamentalmente diferentes. Há uma "Geopolitik", uma "geopolitique” [...] Cada nação tem a geopolítica que pretende [...]

Hans W. Weigert (1942, p. 22-23)

O presente capítulo pretende verificar, retrospectivamente, grandes traços da escola geopolítica brasileira; a seguir, buscaremos observar o curso mais recente da visão brasileira.

Podemos dizer que há uma rica tradição, naturalmente com altos e baixos, na formulação sistemática de um pensamento geopolítico brasileiro, de longa trajetória. Assim, este pensamento constitui uma Escola Geopolítica brasileira - no sentido em que propõe Weigert, na epígrafe que introduz este capítulo, de que toda geopolítica é essencialmente nacional. Uma Escola, podemos dizer, no sentido de que há uma formulação sistemática, variada, e na qual há gerações de autores. Não, absolutamente, no sentido de que haja uma linha única. Nesse sentido, iniciemos com uma breve retrospectiva do curso desta Escola geopolítica brasileira.

Nestas notas sobre a Escola geopolítica brasileira, devemos começar observando-a vis-à-vis com as singularidades geográficas brasileiras. Desse modo, comecemos por observar estas singularidades espaciais brasileiras, que por sua vez, conferirão importantes especificidades à geopolítica brasileira.

Desde Mário Travassos - intérprete pioneiro da geopolítica brasileira, como se vê abaixo -, ponderamos que, no caso brasileiro, nossa característica física dual, marcada pelo antagonismo entre um território que, a um só tempo, é "meio continente" e possuidor de um dos maiores litorais do mundo, portanto, dotado de continentalidade e maritimidade, antes de ser considerado um antagonismo e uma oposição insuperável, 
é preciso ter em mente que se trata de um dado geográfico objetivo que precisa ser considerado em nossa percepção geopolítica; somos, pois, território misto, anfíbio.

Quanto a continentalidade, nosso território de $8.515 \mathrm{~km}^{2}$ (5 $5^{\circ}$ maior do mundo) representa cerca de $47 \%$ da massa territorial sul-americana. As fronteiras terrestres, de 15.719 quilômetros, é a terceira maior do mundo, da mesma maneira em que somos o $3^{\circ}$ maior país do mundo em número de países vizinhos no mundo (o Brasil faz fronteiras com 10 países, somente atrás de China e Rússia, com 14 vizinhos fronteiriços cada).

Somos um país de relevante maritimidade. Os 7.491 quilômetros de faixa litorânea torna o nosso país o maior território marítimo do Atlântico Sul - o mare nostrum por definição. Assim, a maritimidade brasileira se dá, sobretudo, pelo imenso território no mar que a projeção litorânea no Atlântico permite soberania, de acordo com as regras internacionais pactuadas na Convenção dos Direitos do Mar.

Como afirma a Marinha do Brasil:

\begin{abstract}
hoje, os espaços marítimos brasileiros atingem aproximadamente 3,5 milhões de $\mathrm{km}^{2}$. O Brasil está pleiteando, junto à Comissão de Limites da Plataforma Continental (CLPC) da Convenção das Nações Unidas sobre o Direito do Mar (CNUDM), a extensão dos limites de sua Plataforma Continental, além das 200 milhas náuticas $(370 \mathrm{~km})$, correspondente a uma área de $963 \mathrm{mil}$ $\mathrm{km}^{2}$. Após serem aceitas as recomendações da CLPC pelo Brasil, os espaços marítimos brasileiros poderão atingir aproximadamente 4,5 milhões de $\mathrm{km}^{2}$. Uma área maior do que a Amazônia verde. Uma outra Amazônia em pleno mar, assim chamada, não por sua localização geográfica, mas pelos seus incomensuráveis recursos naturais e grandes dimensões ${ }^{59}$.
\end{abstract}

Esta característica mista do território pode vir a ser uma vantagem estratégica de grande monta.

É válido lembrar, aqui, a advertência de Mackinder, que ao aventar à possibilidade de "os chineses, organizados pelos japoneses, chegarem a vencer o império russo e conquistarem seus territórios", a China adquiriria vantagem estratégica sem igual para o domínio da massa terrestre eurasiana. Afinal, "simplesmente porque agregaria uma frente oceânica aos recursos do grande continente, vantagens que os

${ }^{59}$ Disponível em: <http://www.mar.mil.br/menu v/amazonia azul/html/definicao.html $>$. Acesso em: 05 nov. 2012. 
russos, ocupantes da região pivô, todavia não puderam gozar" ${ }^{\prime 60}$. Em menor escala, é o que ocorre com o território brasileiro: amplas possibilidades de polarização da massa territorial sul-americana agregando projeção ao Atlântico Sul - e a medida que avança o processo de integração e conformação do polo sul-americano, abrem-se condições para projeção ao Pacífico e ao Caribe.

\title{
A Escola Brasileira e o pensamento estratégico em breves traços
}

Pode-se afirmar que a constituição do pensamento geopolítico brasileiro está relacionado à própria constituição da nação e do meio físico (território), no qual se desenvolve o Estado.

Muitos consideram Portugal, a quem somos tributários de nossa origem nacional, o primeiro Estado-nação do velho continente. Para CABRAL,

\begin{abstract}
o histórico acontecimento da criação do reino de Portugal no século XII veio a consagrar o primeiro Estado-nação europeu, o qual se tornaria primeira potência marítima mundial na aurora dos tempos modernos. No ápice desse processo se ergue a figura do rei D João II, o Príncipe Perfeito, um grande estrategista da Casa de Aviz que foi o construtor maior de Tordesilhas, marco original do sistema internacional moderno e contemporâneo e da formação histórica do Brasil (CABRAL, 2004).
\end{abstract}

A negociação do Tratado de Madri de 1750, negociado pelo brasileiro nascido em Santos, Alexandre de Gusmão, poderiam conferir a este o status de primeiro geopolítico brasileiro, no sentido mais estrito do termo. Gusmão, como podemos verificar na célebre frase de Jaime Cortesão: "dava-nos 'de jure' aquilo que bandeirantes já nos haviam dado de fato".

Ao referir-se aos bandeirantes e seu papel na expansão do território, chamamos atenção para o fato do povo ser visto como fator motriz da nacionalidade, algo que poderíamos também localizar nos guerreiros de Guararapes, atores da épica expulsão do grande império existente da época, os holandeses, ainda no século XVII.

No início do século XIX, a própria transferência da corte portuguesa para o Rio de Janeiro, diante da invasão napoleônica do Reino - configurando a primeira e única

${ }^{60}$ MACKINDER, Halford J.. El eje geográfico de la Historia. In: RATTENBACH, Augusto B. (Org.). Antologia Geopolítica. Buenos Aires: Editorial Pleamar, 1985. p. 78-81. 
corte europeia a transferir, mesmo que temporariamente, sua sede. Fato que completou, recentemente, 200 anos -, teve grande papel na constituição do território e do Estado brasileiro $^{61}$, sendo fato revelador não apenas da interligação e da simbiose entre Brasil e Portugal, mas, igualmente, acontecimento estratégico que permitiu a sobrevida da direção política máxima do Estado português.

Mas sem dúvida, podemos considerar como grande precursor de nossa Escola Geopolítica o pai da pátria, José Bonifácio de Andrada e Silva. Antes de mais nada, por sua capacidade de lograr uma transição da condição colonial para a independência plena, sem rupturas, que refundassem o Estado. Na verdade, transplantou-se o Estado português e abrasileirou-se a Casa de Bragança, num movimento que permitiu a manutenção do vasto território conquistado em três séculos de colonização. Na origem da pátria, uma forte cisão com nossas origens nacionais, muito provavelmente - como se deu na América espanhola - teria dividido profundamente os brasileiros no nascedouro da nação, causando efeito centrípeto sobre o território.

Assim, nosso argumento no sentido de que Bonifácio foi nosso primeiro grande geopolítico se sustenta na sua contribuição para a manutenção do vasto território, unido sob a direção política do imperador - condição singular para levar adiante a própria estruturação da nação, uma vez que são distintas as perspectivas estratégicas de uma nação conformada por grande território de outras com menor dimensão espacial. Desse modo, a "obra geopolítica" fundamental de José Bonifácio é sua contribuição decisiva, no que se refere à transição da colônia para a independência, preservando na totalidade a integridade da América portuguesa - sorte bastante diversa da América espanhola, fragmentada em diversas partes ${ }^{62}$.

Por certo, também, poderíamos argumentar a respeito de sua capacidade de pensar a frente de seu tempo, formulando projetos para a estruturação nacional. Por exemplo, sua alargada e densa visão geopolítica o levou a propor o seguinte projeto:

${ }^{61}$ Cf. MONIZ BANDEIRA, Luiz Alberto. D. João VI e a construção do Estado brasileiro. In: LIGTH, Kenneth. (Org.). A Transferência da capital e corte para o Brasil: 1807-1808. Lisboa: Editora Tribuna da História, 2007.

${ }^{62}$ Cf. CASTRO, Therezinha de. José Bonifácio e a Unidade Nacional. Rio de Janeiro: Biblioteca do Exército, 1984. 
que se levante uma cidade central no interior do Brasil para assento da Corte ou da Regência, que poderá ser na latitude pouco mais ou menos de $15^{\circ} \mathrm{em}$ sitio sadio, ameno, fértil e regado por algum rio navegável. Desse modo, fica a Corte ou assento da Regência livre de qualquer assalto ou surpresa externa e se chama para as Províncias centrais o excesso de povoação vadia das cidades marítimas e mercantis ${ }^{63}$.

Segundo Meira Mattos, “este local estaria nas proximidades de Paracatu, cerca de 200 quilômetros ao sul da atual Brasília",64. Na sequência, defende o patriarca que “desta Corte central dever-se-ão logo abrir estradas para as diversas províncias e portos de mar, para que se comuniquem e circulem com toda a prontidão as ordens do governo, e se favoreça por elas o comércio interno do vasto Império do Brasil”65.

Esta grandiosa tarefa geopolítica proposta por Bonifácio nos Apontamentos, no início do século XIX - tema, ademais, frequente na formulação sistemática da Escola geopolítica brasileira -, incrivelmente, permanece incompleta em pleno século XXI haja vista, por exemplo, as vicissitudes relacionadas a interligação física da Amazônia ao centro-sul brasileiro.

Aliás, Lembranças e apontamentos do governo provisório da província de São Paulo para seus deputados, redigidos por José Bonifácio, em 1821, não apenas é um primeiro texto de geopolítica brasileira, como um verdadeiro projeto nacional - no qual ele propõe, para fixar-se num exemplo representativo de sua alargada visão, o estabelecimento de uma Universidade na cidade de São Paulo (ANDRADE E SILVA, 1821, p. 99).

Contudo, a geopolítica brasileira, enquanto campo de conhecimento específico, aparece com Everardo Backheuser, "o primeiro que começou a sistematizar informações e deu corpo para que esta disciplina se desenvolvesse em território nacional" $" 66$.

\footnotetext{
${ }^{63}$ Lembranças e apontamento do Governo Provisório da Província de São Paulo para seus deputados (1821). In: FALCÃO, Cerqueira p.99 (2006).

${ }^{64}$ ESCOLA SUPERIOR DE GUERRA. O General Meira Mattos e a Escola Superior de Guerra. Rio de Janeiro, ESG, 2007. p. 60.

${ }^{65}$ Cerqueira Falcão (2006), p.99

${ }^{66}$ COSTA FREITAS, Jorge Manoel. A escola geopolítica brasileira. Rio de Janeiro: Biblioteca do Exercito Editora, 2004. p.13-14.
} 
Nesse sentido, Backheuser publicou A estrutura política do Brasil; Notas prévias, de 1926, e Problemas do Brasil, bem como Estrutura geopolítica, de 1933, que podem ser consideradas, estrito senso, obras pioneiras de difusão geopolítica no Brasil.

O título de precursor da geopolítica brasileira também pode ser conferido, pela influência e perenidade de sua obra, ao Coronel Mário Travassos, autor, em 1930, de Projeção continental do Brasil - nome adotado a partir da segunda edição; na primeira, o título era Aspectos Geográficos Sul-americanos -, cuja Introdução à Geografia das comunicações brasileiras, de 1941, foi prefaciada, nada menos que por Gilberto Freyre, o grande intérprete da nacionalidade. É de Travassos a formulação da ideia de que nossa conformação geográfica nacional nos confere a forma de território misto, que dilui a oposição clássica - cara aos mestres Mahan e Mackinder -, a respeito do mar e do território.

Outro grande mestre da geopolítica brasileira nas suas origens é Delgado de Carvalho (1884-1980), tido como um pai da geografia no Brasil. Em seus estudos geopolíticos, "alicerça seus trabalhos no estudo dos fatores povo, Estado, posição e fronteiras" ${ }^{67}$, tendo influenciado largamente a geração seguinte de geopolíticos brasileiros.

Em Projeção Continental do Brasil, Travassos "preconizava a necessidade de adoção, pelos poderes públicos, de uma estratégia de interiorização política, econômica e demográfica (atenuadora do vazio populacional)", proposta tida como inspiradora para programas de Getúlio Vargas, "sobretudo a célebre Marcha para o Oeste",68.

O General Carlos de Meira Mattos (1913-2007), entusiasta da obra, seguidor de Travassos e um dos grandes geopolíticos brasileiros da segunda metade do século XX, ao se referir à obra em questão afirmou o seguinte: "este livro lançou os fundamentos da Geopolítica brasileira para a primeira metade do Século XX”. Para ele:

as soluções sugeridas por Travassos visando à superação dos óbices oferecidos pela geografia sul-americana, situam-se na realização de uma política de transportes que neutralize, a nosso favor, os desequilíbrios

\footnotetext{
${ }^{67}$ COSTA FREITAS, Jorge Manoel. A escola geopolítica brasileira. Rio de Janeiro: Biblioteca do Exercito Editora, 2004. p.13-14.p.16.

${ }^{68}$ Costa Freitas (2004), p.17
} 
potenciais oferecidos pelos antagonismos fisiográficos existentes (...) Em termos de vertebração da massa continental sul-americana sugere ampla conjugação das redes ferroviária, hidroviária e aérea (MATTOS, 2011).

Nesse sentido, Travassos pode ser considerado um precursor, no que diz respeito ao terreno da geopolítica, da proposta de integração sul-americana.

Assim, conclui Meira Mattos:

suas análises e formulações geopolíticas dominaram a mente de intelectuais patriotas e dos oficiais formados pelas Escolas de Estado-Maior do Exército, Marinha e Aeronáutica até a década de 50. Suas ideias coincidiram com os propósitos políticos de fortalecimento do Estado Brasileiro oriundas dos revolucionários de 1930 (ESG, 2007, p. 61-63).

A segunda geração do pensamento geopolítico brasileiro ${ }^{69}$ pode ser representada aqui por três personagens: Golbery do Couto e Silva (1911-1987), o próprio Carlos de Meira Mattos e Therezinha de Castro (? - 2000) -, tidos como "os mais ilustres brasileiros da segunda metade do século passado, no tocante à denominada Escola Geopolítica Brasileira" ${ }^{, 70}$. Em comum, dentre outras questões, a proximidade com as Forças Armadas - sendo os dois primeiros, militares; e Therezinha, professora de institutos militares - e a ênfase no debate geopolítico baseado no binômio "segurança e desenvolvimento".

O General Golbery definiu geopolítica da seguinte maneira:

nada mais é que a fundamentação geográfica de linhas de ação política, quando não, por iniciativa, a proposição de diretrizes políticas formuladas a luz dos fatores geográficos, em particular de uma análise calcada, sobretudo, nos conceitos básicos de espaço e posição (COUTO E SILVA, 1967, p. 64)

Em especial, destaca-se em Golbery o papel de ideólogo das teses anticomunistas e "ocidentalistas" (defesa da "civilização ocidental"), marcas indeléveis de sua obra.

Explicitamente, esta formulação aparece nas formulações do General Golbery do Couto e Silva, que em sua obra clássica, Geopolítica do Brasil (1967), apresenta todo

\footnotetext{
${ }^{69}$ Ressalte-se que a primeira e segunda fase - ou "geração" - não é algo absolutamente rigoroso, servindo aqui apenas como argumentação para efeito deste projeto. Miyamoto (ano apud Costa Freitas, 2004, p. 13/14) -, por exemplo, divide em cinco fases temporais "a evolução do pensamento geopolítico brasileiro".

${ }^{70}$ Costa Freitas (2004), p.05
} 
um capítulo, escrito em 1958, intitulado O Brasil e a defesa do Ocidente, no qual localiza o país como parte de uma civilização cristã, ameaçada primeiro pelo Islã e agora pelo comunismo, ambos procedentes geograficamente do Oriente. Criticando posições "neutralistas" e a bandeira "cômoda e ilusória" de uma "terceira posição" no contexto da guerra fria (COUTO E SILVA, 1967, p. 242), o pensador propõe, sem qualquer ressalva, a adesão plena do Brasil como parte do sistema de "defesa do Ocidente" ameaçado pelo comunismo. Esquemas de pensamento semelhantes encontram-se presentes em escritos de outros próceres do pensamento estratégico de então, tal como o também General Carlos de Meira Mattos.

O fato é que o pensamento estratégico brasileiro conforma, em especial nesse período, indicação de uma Escola de pensamento, cuja característica básica é um

\begin{abstract}
paradigma de valores comum às obras elaboradas após a Segunda Guerra Mundial: respeito pelo sistema liberal de governo, realçando, todavia, o papel da autoridade na sua gestão; defesa da civilização cristã do Ocidente perante a ameaça do comunismo internacionalista; importância de um diálogo estratégico profícuo entre Brasil-Estados Unidos e reconhecimento do status de potência regional a ser desempenhado por aquela na América do Sul (aliado privilegiado). Estando sempre presente que os propósitos defendidos só poderão ser efetivados mediante uma construtiva inserção do Brasil no bloco ocidental democrático, o confronto Leste-Oeste marcará, assim, de forma indelével as teorias produzidas pela Escola Geopolítica Brasileira até meados da década de 1980" (COSTA FREITAS, 2004, p. 113-114).
\end{abstract}

Retornando à obra do General Golbery, observamos que esta, para além de sua posição ferozmente anticomunista, apresenta importantes originalidades. A tese de livre-docência do professor André Martin, denominada Anti-Golbery, faz uma avaliação multilateral e equilibrada, sendo uma análise clássica, de referência, deste controverso personagem.

O General Carlos de Meira Mattos, também busca extrair consequências "práticas" de suas análises geopolíticas ${ }^{71}$. Segundo Cabral:

\footnotetext{
${ }^{71}$ Um exemplo disto é a criação do projeto Calha Norte, de povoamento das fronteiras amazônicas. Segundo Meira Mattos, referindo-se a seu livro "Brasil, Geopolítica e destino" (1975), "animava-nos a criação, pelo governo, do Projeto Calha Norte (1985), cuja implantação vinha a corresponder às ideias que vínhamos defendendo há dez anos". Outros geopolíticos brasileiros viram suas proposições tornarem-se realidade. O general Golbery, tendo sido chefe da Casa Civil da Presidência da República teve condições óbvias de pôr em prática suas teorias de "segurança nacional". Therezinha de Castro, por exemplo, é creditada à fundamentação geopolítica que levaria ao estabelecimento da Base Comandante Ferraz, na
} 
em seu estudo da realidade brasileira o General Meira Mattos, inspirado na obra de Mário Travassos, apontou caminhos para vencer o desafio de um país imenso, localizado na zona tropical equatorial, conseguir desenvolver-se econômica e socialmente e ascender ao primeiro plano mundial (ESG, 2007, p. 15).

Para efeito da presente pesquisa registramos, também, a importância da obra de Meira Mattos (1913-2007) intitulada Geopolítica e Trópicos (1984) ${ }^{72}$ - prefaciada, assim como a obra de seu mestre Travassos, por Gilberto Freyre -, na qual se discute os fatores sociológicos próprios à formação do povo brasileiro que favorecem a projeção geopolítica brasileira.

No pensamento geopolítico de Therezinha de Castro, destaca-se como questão central o tema amazônico, abordando a necessidade de sua ocupação geográfica e humana. Também a questão da presença no continente antártico ocupa lugar em suas formulações. Para efeito da presente pesquisa, é de fundamental importância destacar os estudos mais contemporâneos da autora, pós-“guerra fria", nos quais encontramos a argumentação de que:

hoje a Nova Ordem Mundial - se é que existe ordem - decorrente do fim da 'guerra fria' e da bipolaridade nos apresenta um quadro paradoxal. No campo político e militar há uma concentração de poder numa única potencia, ao passo que no campo econômico identificamos uma multipolaridade onde megapotências econômicas de magnitude semelhante, por sua ação catalisadora, atraem outros países para sua esfera de influência ${ }^{73}$.

A constatação das novas condições resultantes da ordem internacional pósguerra fria, em Therezinha de Castro, perpassa pelo que, em nossa opinião, é elemento fundamental para a reorientação da teoria geopolítica brasileira.

O período e as formulações que se encerram com esta que podemos denominar como a segunda geração dos geopolíticos brasileiros, representadas por estes três personagens, também encerra um longo período em que a geopolítica brasileira foi largamente condicionada pela visão típica da confrontação bipolar da guerra fria, do ocidente contra o comunismo - termos tipicamente golberyano.

Antártica. Como vimos anteriormente, figuras como Mário Travassos também veria suas proposições geopolíticas se materializarem.

${ }^{72}$ Tese de Doutorado em Ciência Política do autor obtida junto a Universidade Mackenzie, em banca presidida pelo sociólogo Gilberto Freyre.

${ }^{73}$ Apud Costa Freitas (2004), p.107. 
Foi um período em que, nas palavras do Almirante Mario César Flores, exministro da Marinha, "nos condicionou doutrinária e materialmente por praticamente 30 anos", contando a partir da assinatura do Acordo militar Brasil - Estados Unidos, em $1952^{74}$ - o qual seria corajosamente rompido pelo presidente Ernesto Geisel (19071996) em 1977. Este condicionamento teve evidentes impactos no pensamento geopolítico brasileiro.

Coincidindo, não por acaso, com o colapso da ditadura militar, e assim, com o início do fim de um período de profunda ligação e aliança ideológica com os Estados Unidos - ainda que não sem contradições - inicia-se um período que podemos denominar de hiato ou "apagão" para o pensamento estratégico.

Esta crise perpassa toda a década de 1980 - a "década perdida" seja no plano econômico, seja em termos de orientação estratégica - até entrarmos num período de grande retrocesso igualmente em termos econômicos e de estatura estratégico-militar, no início dos anos 1990.

Foi no período do governo de Fernando Collor com sua "pá de cal” no programa nuclear brasileiro ${ }^{75}$; bem como do deslumbramento de Fernando Henrique Cardoso com a globalização, representado, dentre outros, por seu discurso no Colégio de México, seguido, pouco depois, pelas gratuitas e unilaterais adesões ao Tratado de NãoProliferação de Armas Nucelares (TNP) e do Regime de Controle de Tecnologia de Mísseis (MTCR), que se resultou no enfraquecimento estratégico-militar do Brasil. Enfim, período de grandes dificuldades para o pensamento estratégico nacional.

No entanto, este período denominado de "apagão estratégico" começou a mostrar sinais de superação com o aparecimento - depois de prolongada reflexão das Forças Armadas, em especial - do documento Política de Defesa Nacional, de 1996. Absolutamente original, o documento em questão esboça uma reação brasileira frente a nova conformação do cenário internacional.

\footnotetext{
${ }^{74}$ FLORES (2004:33) in ALMEIDA PINTO, J. R. de. (Org.). Reflexões sobre defesa e segurança: uma estratégia para o Brasil. Brasília: Ministério da Defesa, 2004 (Pensamento brasileiro sobre defesa e segurança). Volume 1.

${ }^{75}$ Mantido heróica e clandestinamente pelo Comando da Marinha.
} 
O texto se inicia em torno da discussão do reconhecimento da nova realidade, na qual o fim da guerra fria se traduz no fim da "relativa previsibilidade estratégica". Contrapondo-se às teses defendidas pelo próprio presidente da República, o documento apresenta a ideia de que "continuam a ter relevância conceitos tradicionais como soberania, autodeterminação e identidade nacional". Observa-se que o país não está "livre de riscos", identificando, ainda que de forma difusa, sem nomear, "ameaças ao seu patrimônio e aos seus interesses vitais".

Diante deste cenário, propõe-se, como orientação estratégica, "uma postura estratégica dissuasória de caráter defensivo" -, admitindo que no caso de conflito as Forças Armadas não tenham que "se limitar estritamente à realização de operações defensivas" -, propondo, assim, "uma estrutura militar de credibilidade capaz de gerar efeito dissuasório eficaz".

O passo seguinte para a reestruturação de uma orientação estratégica brasileira se daria em 1999 com a criação do Ministério da Defesa - num primeiro momento, pode-se dizer, tal iniciativa teve como intuito aproveitar uma tendência internacional, que visava otimizar custos com a nova estrutura.

Fruto de contradições, de idas e vindas, de um governo iniciado com uma orientação explicitamente alinhada às tendências do chamado Consenso de Washington, a gestão Fernando Henrique Cardoso foi paulatinamente sendo absorvida por um maior realismo , no que diz respeito ao grande jogo das relações internacionais, e aos poucos flexibilizou sua empolgação com a ordem internacional surgida com o fim da União Soviética. Empolgado, inicialmente, com as tese de livre-comércio, inclusive com a proposta norte-americana da Área de Livre Comércio das Américas (ALCA), Fernando Henrique Cardoso flexibilizou esta posição ao declarar, na Cúpula das Américas (2001), em Quebec, no Canadá, que a "ALCA é uma opção, não um destino" e, ainda, ao organizar, um ano antes (2000), em Brasília, a primeira reunião de presidentes da América do Sul, ainda que fortemente condicionada pela agenda de organismos extrarregionais, como o BID, de estruturação da IIRSA (Iniciativa para a Integração Regional Sul-americana). Eventos que, ainda que extrapolem a questão estratégicomilitar, guardam profunda relação com a condição geopolítica nacional. 
É no período de embate de setores nacionalistas contra a ALCA, que, aliás, começa a se afirmar o que podemos denominar como terceira geração de geopolíticos brasileiros. Nesse sentido, podemos afirmar para efeito de sistematização, que o ato da demissão do embaixador Samuel Pinheiro Guimarães do Ipri (Instituto de Pesquisas de Relações Internacionais), do qual era diretor, por manter uma posição diferente do então chanceler Celso Lafer, em abril de 2001 marca paradoxalmente o fim de um período e o início de outro. Afinal, há apenas três meses de iniciado o novo século, a demissão de Samuel antecedeu o que viria a ser, 20 meses depois, em janeiro de 2003, a posse do próprio Samuel e do embaixador Celso Amorim, a frente do mesmo Itamaraty respectivamente nas funções de Secretário Geral e Ministro das Relações Exteriores, e assim, o descortinamento de uma nova fase relativa à inserção internacional do Brasil.

Essa nova fase, ainda que não inteiramente inédita, pois se apoia em outros momentos nobres da busca por maior autonomia nacional no cenário internacional, tais como o período da política externa independente, na primeira metade dos anos 1960, e no chamado "pragmatismo responsável" do período Geisel, caracteriza-se, entretanto, por condições singulares, seja do quadro internacional, seja das próprias condições internas do Brasil, iniciando uma fase, que somando os dois governos de Lula e o início do governo Dilma, já conta uma década de uma orientação internacional "altiva", para usar expressão do ministro Amorim.

Neste contexto, o surgimento de um renovado pensamento geopolítico brasileiro na alvorada do século XXI era, e continua sendo, uma necessidade dada às características brasileiras e a sua latente e contida ascensão. 


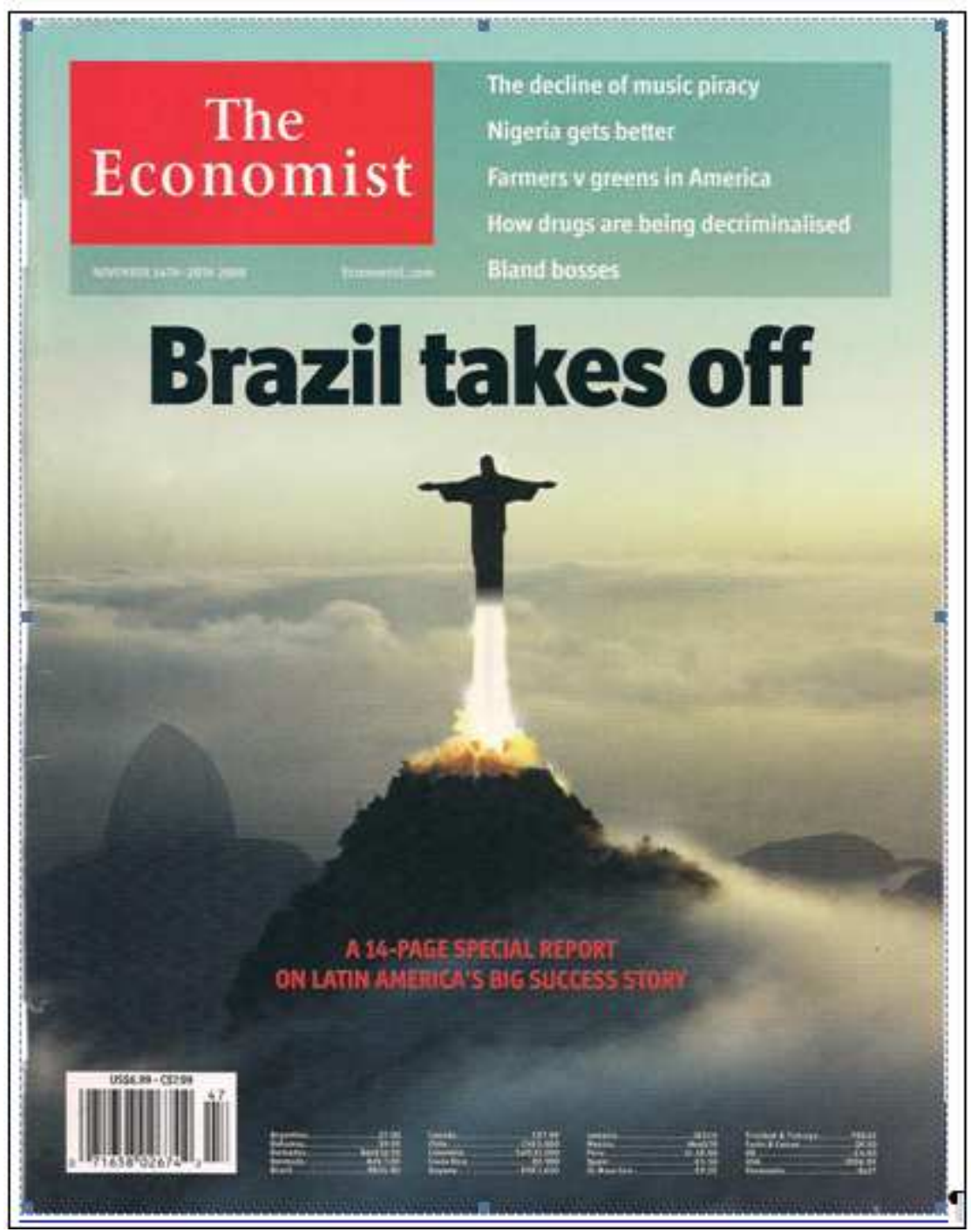

ILUSTRAÇÃO 02

O novo pensamento geopolítico, especialmente na sua dimensão estratégicomilitar - ou geoestratégica - vai se delineando com maior precisão ao longo da primeira década do século XXI e inicio desta segunda. Desse modo, apresentemos a seguir os documentos que são considerados como base desta renovação.

O governo do presidente Luis Inácio Lula da Silva, logo no seu início, promoveu, a partir do Ministério da Defesa, um importante ciclo de debates sobre atualização do pensamento brasileiro em matéria de defesa e segurança, entre os anos de 2003 e 2004. Destas reflexões, registradas em quatro volumes publicados em 2004, 
resultam a base para a publicação, no ano de 2005, de nova edição relativa à Política de Defesa Nacional (PDN), que substitui a versão comentada acima, e publicada em 1996.

A nova PDN dá um novo e importante passo na estruturação de nosso pensamento estratégico e antecipa teses que aparecerão com mais nitidez na Estratégia Nacional de Defesa, de 2008.

Uma importante novidade na PDN de 2005 se dá na leitura do ambiente internacional, aparecendo pela primeira vez, algo que se afirmará nos próximos documentos de orientação estratégica. Trata-se da percepção de que:

Neste século, poderão ser intensificadas disputas por áreas marítimas, pelo domínio aeroespacial e por fontes de água doce e de energia, cada vez mais escassas. Tais questões poderão levar a ingerências em assuntos internos, configurando quadros de conflito (PDN, 2005, p. 2).

E,

a questão ambiental permanece como uma das preocupações da humanidade. Países detentores de grande biodiversidade, enormes reservas de recursos naturais e imensas áreas para serem incorporadas ao sistema produtivo podem tornar-se objeto de interesse internacional (PDN, 2005, p.3).

Ao localizar ameaças relacionadas ao que denominaremos como ativos estratégicos - "fontes de água doce e de energia" e "grande biodiversidade, enormes reservas de recursos naturais e imensas áreas para serem incorporadas ao sistema produtivo" - a PDN dá importante passo na redefinição do que nos ameaça no ambiente do novo século XXI.

A PDN também dá passos mais precisos na definição de nosso entorno geoestratégico - que como veremos, evoluirá nos documentos, alargando-se e tornandose mais nítido.

Desse modo, fixa que, "o subcontinente da América do Sul é o ambiente regional no qual o Brasil se insere". Define, ainda, que "o País visualiza um entorno estratégico que extrapola a massa do subcontinente e incluiu a projeção pela fronteira do Atlântico Sul e os países lindeiros da África”. Em seguida, localiza no plano do interesse estratégico a possibilidade, via integração regional, de obter acesso ao Oceano Pacífico. Apresenta o documento que "a ampliação e a modernização da infraestrutura 
da América do Sul podem concretizar ligação entre seus centros produtivos e os dois oceanos, facilitando o desenvolvimento e a integração" (PDN, 2005, p.3).

Como orientação estratégica geral, a PDN 2005 mantém a ideia de que devemos ter "postura estratégica baseada na existência de capacidade militar com credibilidade, apta a gerar efeito dissuasório", mas ao contrário da versão de 1996, retira a desnecessária adjetivação "de caráter defensivo", ademais de reafirmar que "no caso de ocorrer agressão ao País, empregará todo o poder nacional, com ênfase na expressão militar" (PDN, 2005, p. 6).

Contudo, foi em 2008 que a orientação estratégica brasileira deu um salto qualitativo, em termos de nitidez e precisão, atualizando os grandes desafios à luz da realidade internacional cambiante. Trata-se da publicação, em dezembro deste ano, da Estratégia Nacional de Defesa (END).

Num texto de orientação nacionalista, a END, pode-se dizer, é o primeiro esboço mais nítido da "grande estratégia",76 brasileira - ou, em outras palavras, da orientação geopolítica renovada do país. Antes de mais nada, para esclarecer o vínculo entre Estratégia de Defesa e Estratégia de Desenvolvimento, cabe destacar o seguinte:

Estratégia nacional de defesa é inseparável de estratégia nacional de desenvolvimento. Esta motiva aquela. Aquela fornece escudo para esta. Cada uma reforça as razões da outra. Em ambas, se desperta para a nacionalidade e constrói-se a Nação. Defendido, o Brasil terá como dizer não, quando tiver que dizer não. Terá capacidade para construir seu próprio modelo de desenvolvimento (END, 2012, p.8).

A formulação da END foi determinada por decreto presidencial e assinado às vésperas do dia 7 de setembro de 2007, vindo a ser publicada em 15 de dezembro de 2008. Foi sistematizada - e formalmente assinada - pelos então ministros da Defesa, Nelson Jobim, e de Assuntos Estratégicos, Roberto Magabeira Unger.

\footnotetext{
${ }^{76}$ Liddel Hart sustenta que "o termo 'grande estratégia' serve para dar um sentido de 'execução de uma política', pois seu papel é o de coordenar e dirigir todos os recursos de uma nação ou de um grupo de nações, para a consecução do objetivo político, visado com a guerra, que é definido pela política. A grande estratégia deve avaliar e fortalecer os recursos econômicos e o potencial humano das nações a fim de suportar as forças armadas. Não se deve esquecer os fatores morais, pois incentivar o espírito combativo de um povo é muitas vezes mais importante do que possuir formas mais concretas de poder. O poder militar é um dos instrumentos com que conta a grande estratégia para, juntamente com a ação financeira, diplomática, comercial e particularmente ética, enfraquecer a vontade de luta do adversário" (apud Escola de Guerra Naval, p.4/VI-5, 1998).
} 
Três grandes temas, ou "três eixos estruturantes", constam na END: a reorganização das Forças Armadas, a reestruturação da indústria brasileira de material de defesa e a política de composição dos efetivos das Forças Armadas. Outra grande novidade é a definição de três setores estratégicos a serem priorizados: o espacial, o cibernético e o nuclear, cujo desenvolvimento fica a cargo, respectivamente, da FAB, do Exército e da Marinha. O documento apresenta, ainda, orientações específicas para as três Forças, atualizando e precisando suas tarefas.

Uma importante novidade, de largas consequências, é a definição de que "a base da defesa nacional é a identificação da Nação com as Forças Armadas e das Forças Armadas com a Nação" (p.37), alicerçada na ideia de que:

a Nação brasileira foi e é um projeto do povo brasileiro; foi ele que sempre abraçou a ideia de nacionalidade e lutou para converter a essa ideia os quadros dirigentes e letrados. Este fato é a garantia profunda da identificação da Nação com as Forças Armadas e destas com a Nação (p.40).

Nesse sentido, verifica-se na diretriz de número 12 que:

\begin{abstract}
as forças convencionais cultivem alguns predicados atribuídos a forças nãoconvencionais. (...) A conveniência de assegurar que as forças convencionais adquiram predicados comumente associados a forças não-convencionais pode parecer mais evidente no ambiente da selva amazônica. Aplicam-se eles, porém, com igual pertinência, a outras áreas do País. Não é uma adaptação a especificidades geográficas localizadas. É resposta a uma vocação estratégica geral.
\end{abstract}

A importância desta definição se relaciona com outra decisão estratégica rascunhada, como observamos nas PDN's de 1996 e de 2005 -, que localiza na capacidade de dissuasão a base de nossa orientação estratégica.

$\mathrm{Na}$ END, se dá um passo adicional. Explicitamente, na diretriz número 1, define-se o objetivo de "dissuadir a concentração de forças hostis nas fronteiras terrestres, nos limites das águas jurisdicionais brasileiras, e impedir-lhes o uso do espaço aéreo nacional". Para efetivar capacidade de dissuasão, a END, na Diretriz de número 4, apresenta a necessidade de priorizar a "mobilidade estratégica", conceituada como "capacidade de responder prontamente a qualquer ameaça ou agressão: a mobilidade estratégica”.

Outra importante definição da END se dá com relação ao reequipamento das Forças Armadas. Nesta questão, destaca-se a assinatura, no dia 7 de setembro que 
seguiu à divulgação da END - exatamente 7 de setembro de 2009 - de amplo acordo militar com a França, contando com a presença do então presidente Nicolas Sarkozy. É com os franceses que se obtém um acordo que resulta na transferência de tecnologia para aquele que será o principal instrumento para a efetivação da política de dissuasão brasileira: o casco do submarino a propulsão nuclear, possibilitando passos na aquisição deste vetor chave ${ }^{77}$.

Estas são algumas das importantes orientações propostas pela END de 2008. Como não poderia deixar de ser, trouxe reações significativas de outros atores estratégicos. Em especial, chama atenção um telegrama diplomático assinado pelo então embaixador norte-americano, em Brasília, Clifford Sobel, datado de 09 de janeiro de $2009^{78}$ - menos de um mês após o lançamento da END -, no qual se faz uma análise do documento. Irônico, o texto critica a "tradicional paranoia brasileira relativa às atividades de organizações não governamentais e outras forças estrangeiras obscuras que são popularmente vistas como potenciais ameaças à soberania do Brasil" - como se as intervenções por recursos naturais e a utilização de ONG's como instrumentos políticos de Estados nacionais não fossem um fato - e "elefantes brancos politicamente populares tais como um submarino movido à energia nuclear".

Em termos de posicionamento estratégico, é constante a pressão sobre o Brasil. Analistas, órgãos de comunicação e até governos estrangeiros, pedem "reponsabilidade" ao Brasil - isto é, alinhamento às posições das grandes potências ocidentais - como forma, por exemplo, de apoiar nossa ascensão a membro de um Conselho de Segurança das Nações Unidas reformulado. Nada mais falso. Países "vira-latas" serão sempre tratados como tal. Mas a pressão, como se vê nesta capa de prestigiada revista internacional, é frequente.

\footnotetext{
${ }^{77}$ Ressalte-se que o reator do submarino, que realiza a propulsão nuclear, não é parte do acordo com os franceses. Este acordo refere-se explicitamente a transferência de tecnologia do caso; o reator está sendo desenvolvido pela Marinha, no Centro Tecnológico da Marinha (CTMSP), localizado no campus da Universidade de São Paulo (USP) e nas instalações localizadas em Aramar, na cidade de Iperó, próxima a Sorocaba.

${ }^{78} \mathrm{O}$ telegrama foi vazado no lote de documentos divulgados pelo site Wikileaks. O documento em questão pode ser consultado em: <http://www1.folha.uol.com.br/poder/839335-eua-fazemduras-criticas-a-estrategia-nacional-de-defesa-leia-telegrama-em-portugues.shtml>. Acesso em: 04 nov. 2012.
} 


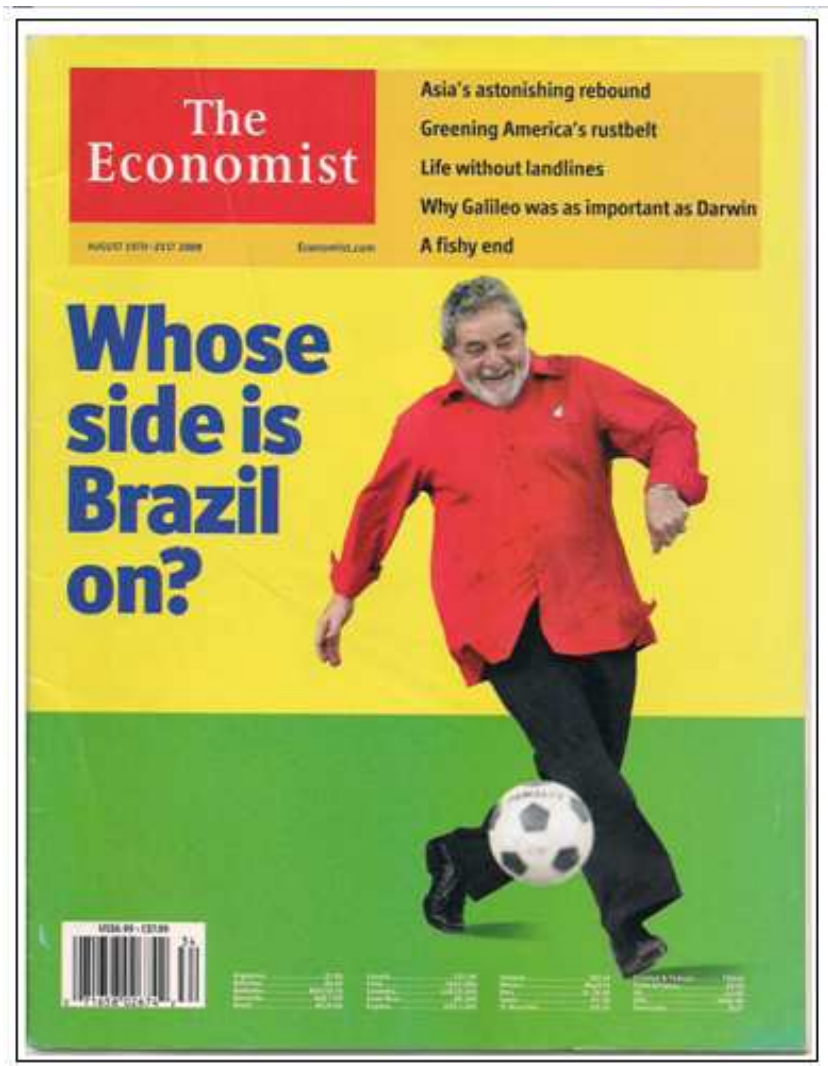

ILUSTRAÇÃO 03

$* * *$

Finalmente, a orientação estratégica brasileira dá um novo salto com a recente publicação, e envio ao Congresso Nacional, em 17 de julho de 2012, de três documentos que reúnem, com precisão ainda maior em relação aos documentos anteriormente vistos, de elementos que podemos denominar de esboço ou linhas de uma "grande estratégia" brasileira $^{79}$. Trata-se do Livro Branco de Defesa Nacional, e de atualização dos dois documentos anteriores: o da Política Nacional de Defesa, que ganha nova versão em relação aos textos de 1996 e 2005, e a Estratégia Nacional, que também está atualizada em relação ao texto de 2008. Desenvolveremos a análise destes documentos nas conclusões a seguir.

${ }^{79}$ Conforme defendemos em recente artigo intitulado O Brasil esboça sua "grande estratégia" notas sobre a Política, a Estratégia e o Livro Branco de Defesa Nacional (CARMONA, 2012) 


\section{CONCLUSÕES}

\section{A geopolítica de Mahan e Mackinder e a "grande estratégia" brasileira}

A guisa de conclusão da presente Dissertação, buscamos observar em que medida as recomendações dos dois grandes autores da geopolítica clássica - Mahan e Mackinder - podem ser observadas no esboço da "grande estratégia", presentes nos três documentos básicos da orientação brasileira contemporânea em matéria de Defesa, recentemente publicados, e que somados aos três que os antecederam, contém elementos desta nova percepção geopolítica brasileira. Assim, aqui tratamos de analisar grandes temas presentes em Mahan e Mackinder, relacionando-os aos debates propostos no Livro Branco de Defesa Nacional e nos dois documentos anteriores: da Política Nacional de Defesa, que em 2012 ganha uma nova versão em relação aos textos de 1996 e 2005, e a Estratégia Nacional de Defesa, igualmente recém atualizada em relação ao texto de 2008.

Nesse contexto, buscamos inclusive considerar ajustes que poderiam ser observados na formulação sistemática da "grande estratégia" - aliás, buscar recomendações aplicadas é da tradição dos estudos geopolíticos.

\section{Recomendações relacionadas ao novo cenário estratégico}

Um primeiro tema relaciona-se ao debate que buscamos introduzir no terceiro capítulo, a saber: em que medida a evolução e as grandes tendências do cenário estratégico global causam impactos no equilíbrio de forças no mundo, e mais especificamente, quais suas repercussões para a América do Sul e para nosso entorno geoestratégico?

Afinal, no ambiente de um "sistema político fechado" - cada vez mais fechado e certamente muito mais do que em 1904, quando Mackinder cunhou esta expressão qualquer peça que se move no grande tabuleiro de xadrez global - para usar a expressão de Brzezinski - impacta sobre o equilíbrio geral do sistema, ainda mais num mundo de 
conformação crescentemente multipolar. Não há posições estáticas num sistema internacional intrinsicamente dinâmico.

No esquema mackinderiano, o hemisfério americano, e, sobretudo, a América do Sul, são regiões absolutamente periféricas, localizando-se no chamado insular crescent, na terra marginal. Nesse sentido, em que medida isso se mantém? Em que medida se altera na nova conformação geoestratégica global?

De fato, mantém-se a centralidade da Eurásia - quem a domine, dominará duas das três regiões mais avançadas do mundo, lembrou-nos Brzezinski. Entretanto, são os Estados Unidos, como vimos, para além de seu declínio relativo, a maior nação do mundo em termos de poderio político, econômico, militar, científico, tecnológico e cultural-ideológico.

$\mathrm{Na}$ busca por manter esta posição relativa no cenário internacional, é de uma importância basilar o domínio hemisférico - ou a hegemonia hemisférica - como base para a hegemonia norte-americana no mundo.

Assim, há um relançamento da iniciativa hemisférica norte-americana - após algum período de aparente distanciamento; na verdade, podemos melhor qualificar como perda de influência estadunidense derivado da eleição de um conjunto de governos de corte nacionalista e mesmo de esquerda na região.

Um sintoma da renovação da preocupação estratégica norte-americana em relação à América Latina é o fato de no último período, em tom alarmista, haver diversas manifestações governamentais ou de think-thanks protogovernamentais norteamericanos, alertando para a perda de influência desse país na América Latina vis-à-vis com o aumento da presença de potências extra-hemisféricas, como China, Rússia e mesmo do Irã.

Dessa forma, analisar a presença hemisférica norte-americana num contexto de continuidade do pensamento estratégico nacional clássico, invariável, da principal potência hemisférica, é importante para examinarmos movimentos recentes que ocorrem em nossa região, dentre eles:

- iniciativas que buscam conter a utilização das imensas riquezas do norte da América do Sul, sobretudo da região Amazônia, blindando-as com argumento 
ecológicos ou humanitários, gerando verdadeiras "zonas de exclusão econômica";

- o significado (no plano geopolítico) do ingresso da Venezuela no Mercosul, rompendo a barreira física e projetando o sul da América do Sul ao Caribe vis-àvis com a pesada oposição, sobretudo, dos grandes meios de comunicação alinhados ao estabilishment, a este ingresso;

- a recente deposição do presidente Fernando Lugo no Paraguai, e o consequente objetivo, malogrado, de fragilização do Mercosul; e finalmente,

- o surgimento, impulsionado, pelo governo mexicano de Calderon, mesmo em final de mandato ${ }^{80}$, e inspirado pelo Departamento de Estado norte-americano, da "Aliança do Pacífico", numa expansão geográfica do Nafta.

Assim, buscando responder a primeira questão, parece-nos que de fato, para a grande potência hegemônica no sistema internacional - a despeito, repetimos, das tendências à multipolaridade -, a centralidade da Eurásia não retira à força de suas iniciativas em relação ao Hemisfério. Noutras palavras, sem a hegemonia hemisférica estaria fracassada ou, pelo menos, fragilizado o relançamento da hegemonia estadunidense no mundo - seu projeto estratégico central.

Entretanto, o deslocamento do eixo geoestratégico e do eixo dinâmico da economia mundial - pela primeira vez desde os descobrimentos do "novo mundo" - do Atlântico Norte para o Pacífico terá importantes efeitos para nosso entorno geoestratégico: a América do Sul e o Atlântico Sul ${ }^{81}$.

De que maneira este deslocamento geoestratégico aumentará a "margem de manobra" para a consecução deste grande objetivo nacional brasileiro, o de integrar a América do Sul num polo de poder, num contexto de multipolaridade, é a questão ainda

${ }^{80}$ Entre os três grandes Partidos mexicanos (PRI, PAN e PRD), o PAN é o aliado mais tradicional dos EUA. Promove, como prioridade diplomática mexicana, a Aliança do Pacífico no apagar das luzes de seu governo, como, aliás, já havia feito outro presidente profundamente aliado dos norte-americanos - Alan Garcia, do Peru -, deixando uma bomba de difícil desarmamento para seu sucessor, Ollanta Humala, tido como o aliado mais próximo ao Brasil.

${ }^{81} \mathrm{Na}$ nova versão da Politica Nacional de Defesa (2012) se vê alargado, contemplando, ademais da América do Sul, do Atlântico Sul e da África, a Antártica e o Caribe. 
não resolvida, uma vez que, como vimos, permanece ativa - e crescente - a capacidade de iniciativa norte-americana na região. Certamente, a resolução dessa equação dependerá do aumento da capacidade de iniciativa brasileira junto a seu entorno geoestratégico.

O deslocamento do eixo dinâmico também possui potencial para exercer força gravitacional centrífuga na América do Sul. A citada Aliança do Pacífico é um sintoma disto, para além do fato de ser uma iniciativa indireta da política de Estado norteamericano, no sentido de dificultar a coesão sul-americana, num projeto liderado pelo Brasil.

Muitos leem positivamente este movimento de deslocamento do eixo dinâmico como uma iniciativa que aumentaria nossa margem de manobra, na medida em que os Estados Unidos estariam envoltos numa espécie de "distração", preocupados com contendas em outras paragens. No entanto, essa ideia, como acima argumentamos, não nos parece a mais provável.

Para responder a questão apresentada, faz-se necessário retroceder a outros objetivos geopolíticos invariáveis dos Estados Unidos, presentes em formulações clássicas de seus principais estrategistas.

Afinal, os Estados Unidos são o país mais influente da América do Sul, ainda que, relativamente a outro período, esta influência, tenha decrescido.

Esse é um fator de primeira grandeza a considerar: a evidente perda ou diminuição de influência estadunidense de sua área de "domínio estratégico" clássico: a área geográfica "abaixo do Rio Grande".

Aqui, como dissemos acima, se coloca a seguinte questão: os Estados Unidos podem manter sua hegemonia no mundo se estão crescentemente perdendo-a no hemisfério americano?

A leitura apresentada no capítulo relativo ao "ambiente estratégico no século XXI", proposta no Livro Branco de Defesa Nacional, caracteriza como tendência dominante, em relação ao cenário futuro, um quadro de incerteza, com "acelerado processo de reestruturação de poder entre os Estados", num contexto em que a multipolaridade "não é, por si só suficiente para garantir que, no atual quadro de transição, prevaleçam relações não conflituosas entre os Estados" ${ }^{\prime 2}$.

${ }^{82}$ LBDN 2012, p.27 
Trata-se de uma leitura que claramente dialoga com a matriz realista de análise do cenário internacional, de evidente corte geopolítico e que nos apresenta um quadro distinto de certa orientação liberal-institucionalista - que é tradicionalmente alinhada às teses decorrentes do processo de globalização do início dos anos 1990. Assim, no quadro da compreensão mackinderiana do sistema internacional, a leitura nos parece um avanço conceitual importante em relação às teses correntes e hegemônicas há até alguns poucos anos.

Ainda, com respeito à leitura de Mackinder sobre o quadro estratégico global, podemos verificar outra questão que guarda atualidade com a era atual. Nesse sentido, é possível estabelecer relações, por analogia, entre a preocupação mackinderiana a respeito de uma aliança russo-germânica que dominasse a terra-coração e, assim, o conjunto da ilha-mundo, e os atuais movimentos das potências ocidentais relacionados à busca de fraturar a unidade dos países BRICS. Afinal, a aliança dos BRICS, revelando uma agenda que guarda mais pontos de unidade que de diferenças, é uma agenda de contestação aberta ao status quo da ordem internacional.

\section{A questão da coesão nacional: características brasileiras}

É forte a ênfase dada por Mackinder, e em boa medida por Mahan, como vimos, ao papel da união nacional, especialmente em contextos de ameaças exógenas. Sobretudo nos exemplos apresentados por Mackinder, é historicamente relevante o papel da unidade nacional na reação às invasões bárbaras para a efetivação da construção dos Estados nacionais na Europa.

No Brasil, guardada as diferenças geo-históricas, não é diferente, no sentido de que daquela que é tida como a primeira manifestação genuína da própria nacionalidade se dá por meio da resistência do povo que pegou em armas contra o império holandês a potência hegemônica da época - nas batalhas dos Guararapes, ainda no século XVII. Assim, podemos dizer que está na lembrança da formação social brasileira, no seu "DNA", a ideia de coesão nacional frente ao inimigo exógeno. Sendo assim, faz-se necessário retomar esta identidade, como dissemos, presente na nossa memória histórica, transladando esta emulação para o período atual. Nossa visão estratégica precisa ter esta questão como algo premente. 
Aqui, podemos agregar o que denominamos como uma vantagem civilizatória, com evidentes consequências geopolíticas: o processo de miscigenação e amalgamento dos brasileiros que resultou num povo novo, como afirmou Darcy Ribeiro.

Somos um povo dotado de forte identidade nacional, que resultou, dialeticamente, na superação das etnias conformadoras da nacionalidade em sua origem para dar lugar a um povo uno, com forte unidade no que diz respeito ao plano da cultura e que se reconhece como brasileiro nos quatro pontos cardeais do território nacional. Por exemplo, diferente dos demais BRICS não possuímos fraturas ou divisões étnicas. No caso brasileiro, nossas divisões se localizam em outras dimensões que não a étnica, sobretudo naquilo que o embaixador Samuel Pinheiro Guimarães chamou de vulnerabilidade ideológica, representadas, dentre outras coisas, pela existência de um setor das elites profundamente vinculado às visões de mundo exógenas.

Assim, dada nossa formação social original, é um equívoco abrir o primeiro capítulo do Livro Branco - justamente o que trata das características brasileiras - e encontrarmos uma epígrafe, um tanto quanto incorreta, assinada pela presidente Dilma Rousseff, aludindo a um "país multiétnico". Se nas origens a nacionalidade carrega essencialmente três etnias distintas, o amalgamento tratou de forjar a nacionalidade grande vantagem estratégica para os brasileiros, que facilitará a necessária coesão nacional para sua realização nacional. Aliás, a epígrafe é contraditória com relação a outro aspecto do texto, precisamente à página 17, que apresenta a seguinte advertência: "indivíduos de origem ameríndia, europeia e africana misturaram-se, resultando numa população miscigenada". Pois desta miscigenação, logramos superar a condição, que poderia ter se afirmado, como o foi em outras partes, numa população multiétnica. A plasticidade do português, entretanto, somada às características sociais próprias da formação brasileira, permitiram a formação de uma nova nacionalidade, dotada de forte identidade cultural que vai muito além dos fenótipos.

Outro problema relativo à unidade nacional deriva de um fator chave na estratégia brasileira de dissuasão, a saber: a necessidade de, tendo em mente o quadro de agressão ao Brasil, nossas Forças Armadas se multiplicarem. Aqui, aparece nos três documentos sobre a estratégia brasileira, o tema da eslasticidade das Forças Armadas. 
Nesse sentido, a dissuasão contra forças "muito superiores" militarmente, que nos ameacem num quadro de deterioração abrupta no cenário internacional, é o cenário proposto como plausível nos documentos. Nestas circunstâncias, a dissuasão se realizará, sobretudo, pela capacidade de elasticidade das Forças Armadas, isto é, pela condição de estas se multiplicarem, apoiadas no povo, em caso de ameaça de agressão externa. A multiplicação das Forças Armadas, convertendo-se no povo em armas, reside, entretanto, na "identificação da Nação com as Forças Armadas e das Forças Armadas com a Nação" (END, 2012)

Ter o povo como base para a defesa da Nação nos é permitido pelas próprias características de nossa formação social. Afinal, inequivocamente, "a Nação brasileira foi e é projeto do povo brasileiro; foi ele que sempre abraçou a ideia da nacionalidade e lutou para converter a esta ideia os quadros dirigentes e letrados" (END, 2012, p. 2425). É o povo brasileiro, muito mais que suas elites - sobretudo, aqueles estratos associados a forças estrangeiras -, que mais compreende a centralidade da questão nacional. Desde os Guararapes, o povo é quem abraça a constituição da Nação.

Ao proporem se apoiar no povo, os documentos levantam a tese de que nossas Forças Armadas devem se preparar para "conjugar as ações convencionais com as não convencionais" - isto é, técnicas e táticas de guerrilha -, criando condições para desenvolver uma "guerra assimétrica, no quadro de uma guerra de resistência nacional" (END, 2012, p.16).

Nestas definições reside o grande mérito da renovação do pensamento estratégico em curso nas Forças Armadas: a possibilidade de aproximá-lo ao pensamento médio do povo brasileiro, desfazendo-se em definitivo de visões que nos foram impostas desde fora, por uma das partes na contenda da guerra fria, que fazia com que o Estado brasileiro declarasse parte do povo como seu "inimigo principal" cindindo, assim, o país e a imprescindível união nacional, base para a realização de suas imensas potencialidades.

Desse modo, a revisão conceitual em curso precisa ser aprofundada e dela extrair consequências. É premente virar a página de um sombrio período histórico que divorciou o povo e as Forças Armadas.

\section{O que ameaça o Brasil}


Nos documentos estratégicos é ressaltado - sobretudo a Política Nacional de Defesa, voltada "essencialmente para ameaças externas" -, que "após longo período livre de conflitos [...] no entanto, é imprudente imaginar que um país com o potencial do Brasil não enfrente antagonismos ao perseguir seus legítimos interesses" (PND, 2012, p.1).

Assim, continua a PND:

neste século, poderão ser intensificadas disputas por áreas marítimas, pelo domínio aeroespacial e por fontes de água doce, de alimentos e de energia, cada vez mais escassas. Tais questões poderão levar a ingerências em assuntos internos ou a disputas por espaços não sujeitos à soberania dos Estados, configurando quadros de conflito (PND, 2012, p. 3-4).

Um exemplo relevante aqui é a soberania nacional com relação à plataforma continental estendida - que perfaz um território de 4,5 milhões de $\mathrm{km} 2$, o que representa $52 \%$ da área continental brasileira - e que, no entanto, a despeito de ter como base a Convenção das Nações Unidas sobre os Direitos do Mar - ratificada por 152 países. Segundo o que consta no Livro Branco brasileiro, "este fato pode se tornar, no futuro, fonte de contenciosos" (p.42), por exemplo, pelo não reconhecimento da soberania brasileira no que diz respeito à exploração de petróleo e outros minérios off-shore.

Não por acaso, a Estratégia Nacional de Defesa orienta que a Estratégia Militar de Defesa dela decorrente - como plano que prepara o país para as chamadas Hipóteses de Emprego das Forças Armadas (itálico) (antes chamadas mais explicitamente de Hipóteses de Guerra) -, considera, fruto das "principais tendências de evolução das conjunturas nacional e internacional”, "a ameaças de forças militares muito superiores na região amazônica” e “a amaça de guerra no Atlântico Sul”. (END, 2012, p.30).

Noutro trecho, a END propõe, no que diz respeito às tarefas do Exército, que:

os imperativos de flexibilidade e de elasticidade culminam no preparo para uma guerra assimétrica, sobretudo na região amazônica, a ser sustentada contra inimigo de poder militar muito superior, por ação de um país ou de uma coligação de países que insista em contestar, a pretexto de supostos interesses da Humanidade, a incondicional soberania brasileira sobre a sua Amazônia (END, 2012, p.15).

Por estas definições, portanto, se considera explicitamente nos documentos estratégicos a possibilidade de contradição de nossos interesses, por partes de potências 
ou de uma coalização de potências, interessadas, por exemplo, em ativos estratégicos cada vez mais escassos.

Hoje a busca pelos países centrais, de acesso desimpedido à matérias-primas se dá basicamente pela esfera diplomática. Mas a ação de rapina manu militari não pode ser descartada no próximo período, sobretudo se, por imperativo do interesse nacional, esse acesso for contraditado, e num caso extremo, bloqueado. Isso não seria uma novidade, haja vista, por exemplo, a recente decisão chinesa de restringir a exportação de terras-raras, mineral tão escasso, bem como cobiçado no mercado internacional.

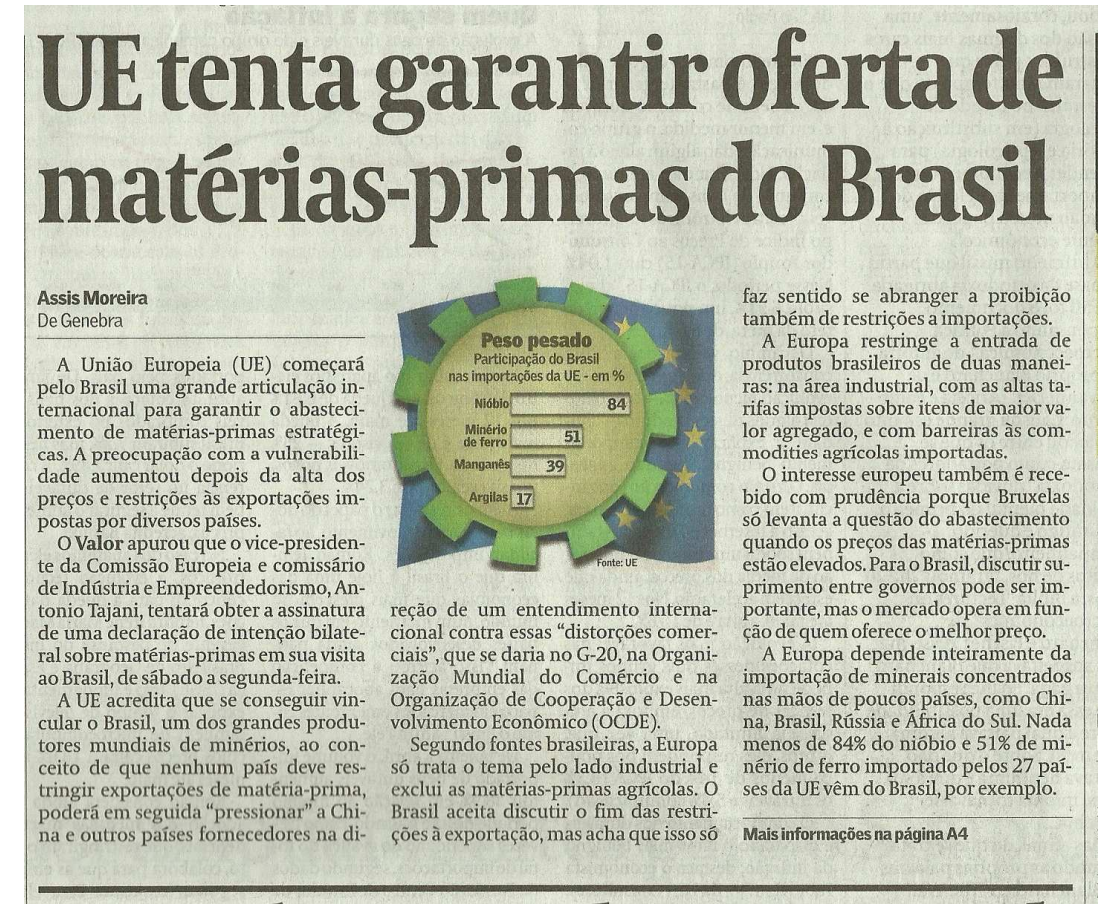

\section{ILUSTRAÇÃO 04}




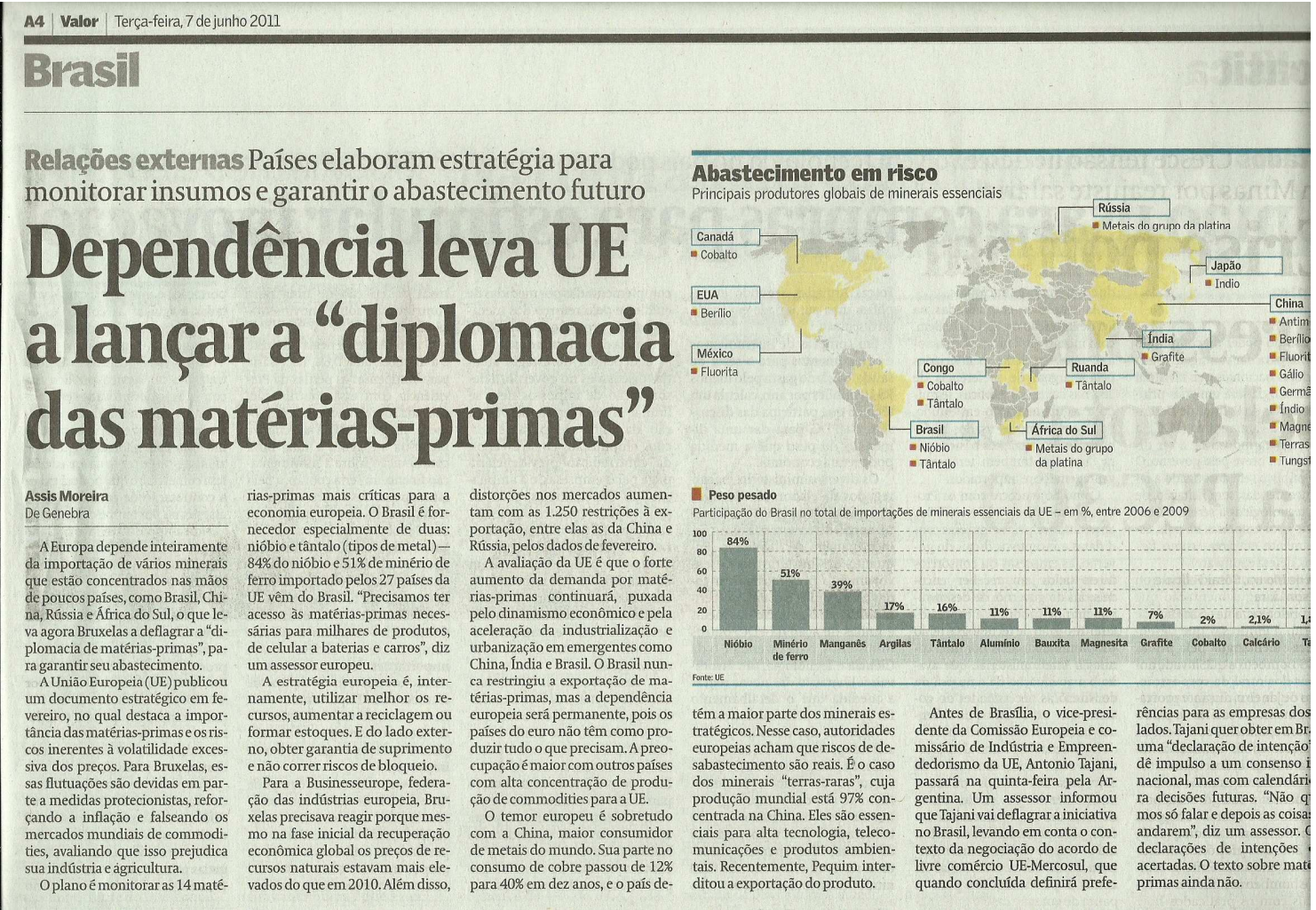

\section{ILUSTRAÇÃO 05}

Fonte: MOREIRA, Assis. Dependência leva UE a lançar a "diplomacia das matérias-primas". Jornal Valor Econômico, 07 jul. 2011, p. A 4.

Relacionado intrinsecamente, portanto, a percepção contemporânea de ameaças presentes na estratégia brasileira é tema de grande centralidade nas teses geopolíticas expostas neste trabalho, a partir da leitura de nossos dois autores clássicos - e que dialoga enormemente com o debate estratégico atual sul-americano ${ }^{83}-$, cujo tema é a questão da importância dos recursos naturais. Primeiro, na percepção de Mackinder e Mahan, como base para prosperidade nacional. Segundo, no debate estratégico contemporâneo, destes ativos estratégicos como bens secutirizados.

Partiremos de uma breve visualização destes principais bens estratégicos, de grande incidência para a determinação de ameaças, conforme o pensamento estratégico brasileiro contemporâneo.

${ }^{83}$ Por exemplo, no debate desenvolvido no âmbito do Centro de Estudos Estratégicos do Conselho Sul-americano de Defesa da União Sul-americana de Nações. Nessa instituição, está em curso um projeto denominado "Prospectivas 2030 " que considera justamente a hipótese de ameaças à América do Sul relacionada à posse destes ativos estratégicos. 
O Brasil é uma grande potência em energia, bem cobiçado e fonte de guerras no último período. O país possui excepcional potencialidade de produção de petróleo, sobretudo com as recentes reserva do Pré-sal. Com estas, o Brasil passará a ser o $6^{\circ}$ maior produtor de petróleo em 2030, com 3,4 milhões de barris diários ${ }^{84}$.

Acrescente-se à isso enormes reservas de gás. Além disso, das volumosas reservas aproveitáveis associadas à extração de petróleo, a Agência Nacional do Petróleo (ANP) estimou, recentemente, a existência de excepcionais reservas em bacias terrestres, dissociada do petróleo, com potencial para quadruplicar a oferta atual. Nesta estimativa, em cinco anos o país será autossuficiente, abdicando da dependência do gás da Bolívia ${ }^{85}$.

Podemos também nos referir, em matéria de energia, a respeito da imensa capacidade hidrelétrica, sendo que boa parte considerada expressiva ainda encontra-se inexplorada. A atual construção das potentes usinas do Rio Madeira, de Belo Monte, e em breve, do Rio Tapajós, permitirão agregar substancial quantidade de energia à matriz elétrica nacional, base para a existência de mais indústrias e, portanto, mais desenvolvimento.

Ressalte-se também a excelência tecnológica e o enorme potencial relacionado aos biocombustíveis. A biomassa vegetal, englobando o etanol, derivado da cana-deaçúcar, a lenha e o carvão provenientes de florestas nativas e plantadas, respondeu, em 2010 , por cerca de $30 \%$ da matriz energética nacional.

O Brasil também possui extraordinárias reservas de urânio. Aliás, apenas Brasil, Rússia e Estados Unidos tem, ao mesmo tempo, expressivas reservas e domínio do ciclo completo de produção de energia nuclear ${ }^{86}$. Segundo o assessor da presidência da

\footnotetext{
${ }^{84}$ Segundo a Economist Intelligence Unit, no primeiro caso, e a Agência Internacional de Energia, no segundo, em dados citados pelo ministro Antônio Patriota (Cf. PATRIOTA, Antônio. Valores Nacionais. Revista Carta Capital, São Paulo, 03 out. 2012. Disponível em: $<$ http://www.itamaraty.gov.br/sala-de-imprensa/discursos-artigos-entrevistas-e-outrascomunicacoes/ministro-estado-relacoes-exteriores/valores-nacionais-entrevista-do-ministroantonio-de-aguiar-patriota-a-revista-carta-capital-3-de-outubro-de-2012>. Acesso em: 18 out 2012).

${ }^{85}$ Cf. Um Brasil cheio de gás. Jornal O Globo, Rio de Janeiro, 28 abr. 2012, Economia, p. 37. Disponível em: <http://oglobo.globo.com/economia/um-brasil-cheio-de-gas-4766632>. Acesso em: 26 jul 2012

${ }^{86}$ A China, por exemplo, está construindo hoje 25 usinas nucleares, destaque para o fato de não possuir urânio. Outro país com potencial consumidor é o Japão, que tem $50 \%$ da geração
} 
Eletronuclear, Leonam Guimarães, o conteúdo energético das reservas de urânio no País é:

\begin{abstract}
da mesma grandeza do volume de óleo já inscrito como reserva provada pela Petrobrás". Temos 309 reservas conhecidas, mais 300 mil prognosticadas e 500 mil especulativas. No cenário otimista, tudo dá 1 milhão de toneladas, da ordem do que tem na Austrália. Isso faria do Brasil a segunda maior reserva do mundo (GUIMAR ÃES, 2012) ${ }^{87}$.
\end{abstract}

O Brasil também é uma potência em termos de minérios essenciais e estratégicos. Nesse sentido, "apenas $30 \%$ do território brasileiro apresenta mapeamento geológico em escala condizente com a pesquisa de jazidas" $" 88$.

Destaca-se, também, a extraordinária capacidade de produção de alimentos, pela enorme extensão de terras aptas a agricultura, num contexto de crescente consumo por um lado, e crescente escassez de terra, inclusive por efeitos climáticos, por outro. A China, por exemplo, se dependesse apenas de suas terras soberanas para a produção de alimentos destinados à sua extensa população, não lograria fazê-lo.

Além de alimentos, o país tem imensa capacidade de produção de proteína animal, possuindo o $2^{\circ}$ maior rebanho bovino - apenas atrás da Índia, que por sua cultura, não o consome -, o $3^{\circ}$ rebanho suíno e o $4^{\circ}$ maior em cabeças de frango. Isso, numa realidade em que a possibilidade de uso de extensas áreas inutilizadas para a pastagem está disponível em nosso imenso território.

Outro bem de grande relevância estratégica para a própria vida humana, e que o Brasil possui em abundância, é a água. Temos quase o dobro de reservas renováveis desse recurso em relação ao segundo país que mais possui este bem, a Rússia (8.233,0 $\mathrm{km} 3 \times 4.498,0)^{89}$. O país conta com a maior reserva de água doce do planeta, com destaque para a Bacia Amazônica - onde recentemente se descobriu formidáveis depósitos subterrâneos na região de Alter do Chão, entre o Pará e o Amapá, bem como mais ao sul do território nacional, nas reservas do Aquífero Guarani - este último compartilhado com os demais países do Cone Sul.

elétrica por fonte nuclear, mas também não tem urânio. Ou mesmo a França, que tem $80 \%$ da geração por fonte nuclear, com controle de algumas minas, mas também não tem urânio.

${ }^{87}$ Disponível em: <http://www.estadao.com.br/noticias/impresso,uranio-merece-status-de-presal-diz-assessor,674618,0.htm>. Acesso em: 05 nov. 2012.

${ }^{88}$ PENNA, Paulo. Jornal Folha de S. Paulo, São Paulo, 27 out. 2010, p. B 11.

${ }^{89}$ Estatísticas, 2009, p.15 
Por fim, o país é uma potencia em biodiversidade; estima-se que exista em nosso território mais de $13 \%$ do total de espécies do planeta. O Brasil também é detentor da maior floresta tropical úmida do planeta. O bioma Amazônia representa cerca de $30 \%$ de todas as florestas tropicais remanescentes do mundo. Sua importância é reconhecida tanto nacionalmente quanto internacionalmente. Isso se deve principalmente à sua larga extensão (4, 2 milhões de km2) e enorme diversidade de ambientes, com 53 grandes ecossistemas $^{90}$. Além da Amazônia, o Cerrado é outro grande bioma do país. Possui uma área de cerca de dois milhões de $\mathrm{km} 2$ (24\% do território nacional) e ocupa a porção central do Brasil

Estas enormes riquezas, em termos de ativos estratégicos, colocam o Brasil numa situação ímpar entre as nações do mundo. Mackinder, como vimos, explorou a relação entre potencialidades naturais e potencialidades econômicas. Mirando o heartland, uma das razões essenciais de conferir à esta área geográfica a enorme vantagem estratégica é atribuída à possibilidade de constituição de um sistema de autarquia, de relativo isolamento desta região devido a posse dos imensos recursos lá existentes.

Mackinder citou visionariamente a América do Sul, como região possuidora destes vastos recursos estratégicos - questionando, porém, o o fato destas riquezas virem a cair em mãos americanas ou alemãs; seu eurocentrismo provavelmente não o permitiu considerar a variável de uma construção autônoma, como a que se encontra em curso em nossa região.

Mais recentemente, como dissemos, o tema dos recursos naturais, ou ativos estratégicos, tem passado a ser tema central na análise geopolítica e geoestratégica comum, especialmente pactuada no âmbito do Conselho Sul-americano de Defesa da Unasul. Afinal, a leitura comum é de que a posse de ativos estratégicos que tendem a escassear no horizonte de médio prazo - água, determinados minérios, fontes de energia, biodiversidade e terras aptas para a produção de alimentos -, podem redundar em contradições agudas, por imperativo do interesse nacional, disciplinar, restringir ou mesmo vetar o acesso de determinados países a esses bens.

${ }^{90}$ SAYRE et al., 2008 
No próprio Livro Branco brasileiro, ao se defender a integração sul-americana, sustenta-se a ideia de se "evitar possíveis ações hostis contra o patrimônio de cada uma das nações da região" (LBDN, 2012, p. 51). Para isso, a estratégia comum sulamericana, que se vai constituindo paulatinamente, consiste, como tem dito em diversos discursos o ministro da Defesa, Celso Amorim, e que está presente, também no próprio Livro Branco, numa orientação estratégica que "conjuga componentes cooperativos e dissuasórios" (LBDN, 2012, p.29). Em outras palavras, numa comunidade de segurança voltada para a cooperação entre seus integrantes e para a dissuasão em relação a forças exógenas, extrarregionais sul-americanas.

Assim, a questão dos bens estratégicos é de grande centralidade na análise geopolítica renovada, brasileira, e mais amplamente, em escala sul-americana.

Vinculada a estes debates, levanta-se a questão relativa ao curso da união e da integração sul-americana, tema chave nos documentos e no pensamento estratégico brasileiro, e na própria Constituição nacional.

Mackinder apontou a possibilidade de grandes estados polarizarem estados menores, ao discutir a diferença de agilidade entre o grande Estado, localizado no coração da Eurásia, e os Estados que o circundam, dá uma importante pista referente à condição que se aplica a nossa realidade regional.

Para ele:

as particulares combinações de poder que se põem em equilíbrio não são sustentáveis; meu argumento é que, de um ponto de vista geográfico, provavelmente girará ao redor de um Estado pivô, que provavelmente haverá que ser sempre grande, mas com uma mobilidade limitada em comparação com as potencias marginais e insulares que o rodeiam.

Dessa forma, o equilíbrio se constituirá a partir de um grande Estado que polarize o entorno. Aqui, certamente, Mackinder poderia estar se referindo, por analogia, ao poder de atração dos grandes Estados em relação aos que os circundam.

A coesão de um polo sul-americano, liderado pelo Brasil no contexto da Unasul, incluindo o heartland sul-americano (ver a contribuição de Mário Travassos na citada obra de referência), um dado da realidade atual, poderia ter o efeito de jogar os Estados 
Unidos, potência com quem se disputa a hegemonia na América do Sul, para as "fimbrias" da região.

As contradições entre os dois polos da América é uma tendência histórica e atual. O filósofo alemão, George W. Hegel, ainda em 1830, apontava que a América, "terra do futuro", teria no futuro "algo assim como uma contenda entre a do Norte e a América do Sul, momento no qual a importância da Historia Universal deverá se manifestar". Henry Kissinger em seu Does América Need a Diplomacy?, de 2001, referindo-se a contradição entre Nafta e Mercosul, "afirmou o perigo que representa a tendência da América Latina de se integrar de modo autônomo e assim, de forma hostil a uma ampla estrutura hemisférica". Dizia o estrategista e ex-secretário de Estado que a "América do Sul buscava definir uma identidade própria, o que estava gerando uma potencial contenda entre Brasil e os Estados Unidos sobre o futuro do Cone Sul" "91.

Nesse contexto, pensamos que se explica em grande medida a renovada iniciativa norte-americana em relação a nossa região. Assim, como apontamos no inicio destas Conclusões, em que medida ações estratégicas recentes, e mais amplamente, a retomada da iniciativa dos Estados Unidos em relação à América Latina não atende a esta fórmula de Mackinder de impedir a coesão de um "polo fechado" sul-americano?

Também, podemos nos apoiar em Mahan, a fim de defender a possibilidade de integração bioceânica- de relevância similar ao preconizado por Mahan, no que concerne aos Estados Unidos, quando sugeriu a construção do Canal do Panamá -, a partir da carteira de projetos de infraestrutura apresentadas no âmbito do Cosiplan (Conselho de Planejamento e Infraestrutura) da Unasul. Para o Brasil, representaria agregar acesso a nova área geoestratégica, essencial na conformação securitária do mundo contemporâneo - como vimos no capitulo III -, o Oceano Pacífico.

A citada carteira de projetos da integração sul-americana tem grande potencial para representar um salto qualitativo na integração da infraestrutura física, de energia e de comunicações em escala sul-americana, como se vê abaixo. Nisto, é grande o interesse estratégico brasileiro, dada o duplo uso destas estruturas.

\footnotetext{
${ }^{91}$ Apud Moniz Bandeira (2008), p. 07, 14 e 15.
} 


\begin{tabular}{|c|c|c|c|c|c|c|c|c|}
\hline \multicolumn{9}{|c|}{ Composición sectorial de la Cartera de Proyectos del COSIPLAN por EID } \\
\hline \multirow{3}{*}{ EID } & \multicolumn{4}{|c|}{ Transporte } & \multicolumn{4}{|c|}{ Energía } \\
\hline & \multicolumn{2}{|c|}{ Proyectos } & \multicolumn{2}{|c|}{ Inversión Estimada " } & \multicolumn{2}{|c|}{ Proyectos } & \multicolumn{2}{|c|}{ Inversión Estimada } \\
\hline & $\mathrm{N}^{\circ}$ & $\%$ & Millones de US\$ & $\%$ & $\mathrm{~N}^{0}$ & $\%$ & $\begin{array}{c}\text { Millones de } \\
\text { US\$ }\end{array}$ & $\%$ \\
\hline Eje del Amazonas & 57 & 12,3 & $6.038,7$ & 9,2 & 6 & 9,8 & 58,1 & 0,1 \\
\hline Eje Andino & 49 & 10,6 & $6.356,1$ & 9,7 & 13 & 21,3 & $2.987,3$ & 5,9 \\
\hline Eje de Capricornio & 72 & 15,6 & $7.739,1$ & 11,9 & 4 & 6,6 & $1.240,0$ & 2,4 \\
\hline $\begin{array}{l}\text { Eje del Escudo } \\
\text { Guayanés }\end{array}$ & 15 & 3,2 & $4.537,3$ & 6,9 & 2 & 3,3 & 3,0 & 0,0 \\
\hline $\begin{array}{l}\text { Eje de la Hidrovía } \\
\text { Paraguay-Paraná }\end{array}$ & 83 & 17,9 & $5.108,8$ & 7,8 & 7 & 11,5 & $1.369,0$ & 2,7 \\
\hline $\begin{array}{l}\text { Eje Interoceánico } \\
\text { Central }\end{array}$ & 57 & 12,3 & $3.786,4$ & 5,8 & 2 & 3,3 & 321,8 & 0,6 \\
\hline Eje MERCOSUR-Chile & 87 & 18,8 & $25.809,7$ & 39,6 & 18 & 29,5 & $18.580,1$ & 36,5 \\
\hline Eje Perú-Brasil-Bolivia & 19 & 4,1 & $3.635,8$ & 5,6 & 6 & 9,8 & $25.922,0$ & 50,9 \\
\hline Eje del Sur & 24 & 5,2 & $2.288,0$ & 3,5 & 3 & 4,9 & 450,0 & 0,9 \\
\hline TOTAL & 461 & 100,0 & $65.144,6$ & 100,0 & 61 & 100,0 & $50.931,3$ & 100,0 \\
\hline
\end{tabular}

\section{TABELA 01}

\begin{tabular}{|c|c|c|c|c|c|c|c|c|}
\hline \multirow{3}{*}{ EID } & \multicolumn{4}{|c|}{ Comunicaciones } & \multicolumn{4}{|c|}{ Total } \\
\hline & \multicolumn{2}{|c|}{ Proyectos } & \multicolumn{2}{|c|}{ Inversión Estimada } & \multicolumn{2}{|c|}{ Proyectos } & \multicolumn{2}{|c|}{ Inversión Estimada ") } \\
\hline & $\mathrm{N}^{\circ}$ & $\%$ & $\begin{array}{c}\text { Millones de } \\
\text { US\$ }\end{array}$ & $\%$ & $N^{\circ}$ & $\%$ & $\begin{array}{c}\text { Millones de } \\
\text { US\$ }\end{array}$ & $\%$ \\
\hline Eje del Amazonas & 1 & 11,1 & 3,1 & 7,0 & 64 & 12,0 & $6.099,9$ & 5,2 \\
\hline Eje Andino & 2 & 22,2 & 0,1 & 0,2 & 64 & 12,0 & $9.343,5$ & 8,0 \\
\hline Eje de Capricornio & 0 & 0,0 & 0,0 & 0,0 & 76 & 14,3 & $8.979,1$ & 7,7 \\
\hline $\begin{array}{l}\text { Eje del Escudo } \\
\text { Guayanés }\end{array}$ & 1 & 11,1 & 0,0 & 0,0 & 18 & 3,4 & $4.540,3$ & 3,9 \\
\hline $\begin{array}{l}\text { Eje de la Hidrovía } \\
\text { Paraguay-Paraná }\end{array}$ & 3 & 33,3 & 37,0 & 82,7 & 93 & 17,4 & $6.514,7$ & 5,6 \\
\hline Eje Interoceánico Central & 2 & 22,2 & 4,5 & 10,1 & 61 & 11,4 & $4.112,7$ & 3,5 \\
\hline Eje MERCOSUR-Chile & 0 & 0,0 & 0,0 & 0,0 & 105 & 19,7 & $44.389,8$ & 38,2 \\
\hline Eje Perú-Brasil-Bolivia & 0 & 0,0 & 0,0 & 0,0 & 25 & 4,7 & $29.557,8$ & 25,4 \\
\hline Eje del Sur & 0 & 0,0 & 0,0 & 0,0 & 27 & 5,1 & $2.738,0$ & 2,3 \\
\hline TOTAL & 9 & 100,0 & 44,7 & 100,0 & 531 & 100,0 & $116.120,6$ & 100,0 \\
\hline
\end{tabular}

TABELA 02. Fonte: Cartera de Proyectos Cosiplan, 2011, Edição: BID/CAF/Fonplata, p. 17 e 18. 
Esta carteira de projetos tem grande importância para compreender o curso da atual integração sul-americana. O Cosiplan, numa importante decisão políticaestratégica, reformulou o IIRSA - Iniciativa para a Integração da Infraestrutura Regional Sul-americana, surgida da Cúpula sul-americana de Brasília, em 2000, ainda no governo de Fernando Henrique Cardoso, dando lugar ao chamado Plano de Ação Estratégico (PAE), que diz respeito à uma grande carteira de projetos de integração física na América do Sul, tendo como horizonte o ano de 2022, no valor de US\$116,1 bilhões, como se vê acima.

Desta carteira de obras, recorta-se um conjunto de 31 projetos com 88 ações voltadas para a integração física sul-americana, reunidas numa Agenda de Projetos Prioritários (API), no valor de US\$13,7 bilhões de dólares.

Destes 31 projetos, 11 estão diretamente relacionados à integração do Brasil com seus vizinhos, e 9 deles estão incluídos no $\mathrm{PAC}^{92}$. Dentre estes, há projetos de nítido interesse geoestratégicos para o Brasil, como a rodovia Boa Vista - Georgetown -, esta incrivelmente não incluída no $\mathrm{PAC}$-, que poderá ser o início da integração física do norte do Brasil com a "ilha das Guianas”, a partir de futura ligação viária que unirá Boa Vista à Macapá, via três Guianas; uma segunda obra física de dimensões estratégicas, que faz jus ao velho projeto geopolítico de Mário Travassos, é o corredor ferroviário de Paranaguá à Antofagasta, que materializa acesso da região sul-sudeste do Brasil ao Oceano Pacifico.

Já no âmbito do Mercosul, aparece o Focem - Fundo de Convergência Estrutural do Mercosul, quase que, todavia, um projeto piloto, tendo em vista seus limitados recursos, de cerca de US\$ 100 milhões/ano, 70\% dele oriundo de contribuição brasileira, mas que já apresenta importantes iniciativas potenciais, dentre elas, a interligação do Uruguai ao sistema elétrico nacional e a construção da ligação elétrica entre Itaipu e a capital paraguaia Assunção.

Importantes, entretanto, estes projetos se mostram tímidos, pouco ambiciosos diante das necessidades estratégicas do Brasil e mais amplamente, da América do Sul.

Os 100 milhões do FOCEM ou os 13, 7 bilhões já definidos no pacote de obras da integração sul-americana contrastam, por exemplo, com recente anúncio do primeiro ministro chinês, Wen Jiabao, que em discurso na sede da Cepal em Santiago do Chile,

${ }^{92}$ Segundo informações do Ministério do Planejamento, em audiência na CREDN da Câmara dos Deputados, junho de 2012. 
no último dia 26 de junho de 2012, anunciou 15 bilhões de dólares para a América do Sul, divididos em 5 bilhões para um certo "Fundo de cooperação China-América Latina" e 10 bilhões de uma "linha de crédito especial" destinada à infraestrutura. A estes valores, poderíamos agregar outros desembolsos, como os 10 bilhões emprestados à Petrobras para a exploração do Pré-Sal, os bilhões envolvidos no chamado "fundo chinês" com o governo da Venezuela ou o financiamento, pelos asiáticos, da ferrovia que interligará o Caribe ao Pacifico colombiano.

Esta timidez exige, no plano estratégico, decisão que resulte em ampliar a capacidade de iniciativa brasileira em relação a nosso entorno geográfico, sul-americano e africano.

O acesso ao Caribe já é realidade para o Brasil, possibilitada pela integração regional. A inauguração da estrada Manaus - Caracas e mais recentemente, com a incorporação da Venezuela ao Mercosul -, fator geopolítico que liga este país ao bloco do sul -, permite avanços na projeção ao norte. O Brasil deveria estimular, em especial, a projeção de poder da Venezuela no Caribe, incentivando e participando como observador e eventual contribuinte, por exemplo, do exitoso mecanismo da PetroCaribe.

Geograficamente, a América do Sul - na verdade, América do leste, na entorse da conformação hemisférica - guarda uma quase que total insularidade, exceto pelo Canal do Panamá, fato este que nos parece, aludindo à tese mahaniana com respeito à vantagem estratégica britânica de sua insularidade em relação ao continente europeu, uma importante vantagem relativa, no sentido de que é diminuta, ou mesmo nula, uma possível invasão militar clássica por terra por parte de atores extrarregionais. Ainda que aqui, por outro lado, se verifica o velho problema apresentado por Spykman a respeito do hemisfério americano, da possibilidade de seu isolamento - ou "cerco" - pelo velho mundo.

Observemos algumas outras questões propostas por Mahan que se relaciona ao debate estratégico brasileiro atual.

Vejamos o tema da propensão à maritimidade de um povo, tema chave na interpretação estratégica mahaniana. O mar está na raíz da formação social brasileira. Pelo mar chegaram a contribuição portuguesa e africana para a formação da nacionalidade. 
Frei Vicente do Salvador (1564- ac. 1635), um dos primeiros intérpretes de nossa formação social, interpretava negativamente o fato de termos uma população, denominada por ele, de caranguejo, agarrada ao litoral. De fato, há uma concentração de aproximadamente $80 \%$ de nossa população em faixa de até duzentos quilômetros do litoral, o que confere enorme maritimidade no brasileiro médio por um lado, mas por outro nos torna mais vulneráveis. Não por acaso, vem de José Bonifácio a primeira proposição para mudarmos a capital para o interior do país.

De fato, o gosto pela praia, a valorização da beleza, tendo em vista o bronzeamento da pele, bem como o gosto pela navegação desportiva ou de lazer, são questões arraigadas na cultura brasileira que favorece a vertente marítima de nossa estratégia nacional.

Entretanto, apoiando-se em Mahan, podemos identificar como fonte de vulnerabilidade nacional o tamanho demográfico relativamente diminuto de nossa população, apenas a $4^{\mathrm{a}}$ da América do Sul em densidade demográfica, empatado com outras duas nações. Assim, a despeito de termos a sexta população do mundo, dado nosso território, temos uma população pequena - projetando-se, inclusive, que em alguns anos, esta tende a diminuir. Eis aqui um problema chave, um projeto estratégico de nação não poderá desconsiderar.

Em síntese, nossa população é essencialmente litorânea, mas diminuta, no que, na visão de Mahan, constitui uma vantagem, no primeiro caso, e uma desvantagem, no segundo.

A propensão dos brasileiros ao mar tem potencial para constituir volumosa força de reserva apta para a Armada, questão importante na visão de Mahan.

É um dado que joga a favor de uma maior autonomia nacional. Não devemos ao acesso ao mar (ou, à relações mercantis com o exterior) o principal de nosso Produto, devido ao nosso extenso mercado interno. Assim, é o Brasil relativamente pouco exposto ao comércio exterior. Se isto, segundo Mahan, pode se constituir numa desvantagem - pois resultaria em menor disposição de expor-se ao mar -, no contexto contemporâneo, constitui-se importante vantagem - vide a relevância deste fator, por exemplo, para a resistência à atual crise internacional, cujo mercado interno nos grandes países é tido como um fator de fortaleza econômica. 
Vinculado à este debate, há outra questão de grande importância que aparece em Mahan. Trata-se da importância de não perder-se em "riqueza fácil ou ilusória", como criticou o autor em relação aos países ibéricos que não aproveitaram a abundância de recursos naturais para desenvolver a manufatura. Trata-se de tema extremamente atual para o curso e o desenvolvimento do projeto nacional de desenvolvimento brasileiro. Afinal, ameaças como a da chamada doença holandesa é ressaltada, sobretudo, por economistas desenvolvimentistas, como um risco relacionado à abundância de matérias primas.

Devemos, também, neste debate, nos atentar à recomendação mahaniana a respeito da importância da salvaguarda dos portos e das rotas de comércio, fonte importante das riquezas nacionais.

Aqui, a despeito do que foi anteriormente dito - baixa exposição externa -, é a via marítima que escoa $95 \%$ de nosso comércio exterior. A proteção desse fluxo, ensina-nos Mahan, é chave para a prosperidade nacional. Na END (2012, p.10), discutese a a importância de se "criar condições para controlar" [...] "linhas de comunicação marítimas".

\section{Forma do litoral e zonas de penetração}

Observando as recomendações de Mahan a respeito de seu país, derivada da conformação física norte-americana, no que diz respeito ao caso brasileiro, podemos localizar uma semelhança e uma vantagem em relação ao país do norte, ambas relacionadas à contiguidade de nosso litoral, caracterizado por extensa e regular conformação física, com 7.491 quilômetros de área praticamente ininterrupta - exceto por foz de Rios, que tampouco é impeditivo à navegação costeira.

Esta conformação nos oferece uma semelhança em relação ao analisado por Mahan, concernente ao seu país, no sentido de que "com a extensa costa marítima dos Estados Unidos, um bloqueio (naval) completo não pode ser mantido efetivamente" dada à extensão do território a bloquear. Assim, sustentava o autor, a tática do inimigo seria "a tentativa de bloquear Boston, Nova Iorque, o Dalaware, o Chesapeake e o 
Mississipi, em outras palavras, os grandes centros de exportação e importação" (MAHAN, 1984, p.35) e a foz de grandes rios.

No caso, brasileiro, o enorme litoral também impediria um bloqueio completo. Nesse sentido, a iniciativa inimiga incidiria em pontos chaves do litoral, em especial os grandes centros urbanos, industriais e econômicos - tais como o Rio de Janeiro, Santos ou Salvador - e zonas de penetração do território, como a foz do Rio Amazonas e do Rio São Francisco, esta localizada entre Sergipe e Alagoas.

Já a notória vantagem da estrutura física do litoral brasileiro decorre do fato de que esta contiguidade trás uma vantagem estratégica em relação ao litoral norteamericano ou do francês, repartido em dois pontos em oposição. Nossa vulnerabilidade, neste caso, são as "portas abertas" ao ingresso no Rio Amazonas ou no Rio São Francisco.

Salta aos olhos a necessidade da rápida estruturação, visando superar latente vulnerabilidade estratégica, da $2^{\mathrm{a}}$ Esquadra Naval da Marinha do Brasil "em área próxima a foz do Rio Amazonas", como podemos verificar nos documentos Estratégia Nacional de Defesa e no $\operatorname{LBDN}^{93}$. Já na END (2012, p.11), encontramos a diretriz de que a Marinha "adensará sua presença nas vias navegáveis das duas grandes bacias fluviais, a do Amazonas e a do Paraguai-Paraná".

Afinal, a contradição de que discorria Mahan, no que concerne às "vias de penetração do território", no caso brasileiro são latentes. Entretanto, se do ponto de vista estratégico, é latente a vulnerabilidade, do ponto de vista do que podemos chamar de "prosperidade nacional", para usarmos um termo mahaniano, e mesmo relacionando as potencialidades ligadas à infraestrutura dual - que possa atender as necessidades de Defesa -, é urgente colocar em marcha um plano hidroviário que permita a plena navegabilidade de nossos principais rio interiores, não apenas os das Amazônia.

\section{A vulnerabilidade no Atlântico Sul: a concentração, no litoral, de forças com as quais podemos ter contradições agudas}

\footnotetext{
${ }^{93}$ Cuja implementação é prevista no LBDN para culminar no longínquo ano de 2031.
} 
Consideramos que nosso problema geoestratégico basilar e nossa vulnerabilidade estratégica chave, interpretando a situação brasileira - pelas lentes de Mahan -, é a concentração de forças potencialmente inimigas em nosso litoral, o Atlântico Sul, posição geográfica vital para a soberania nacional.

Não por acaso, na END (2012, p. 2) verificamos uma definição explícita do que vem a ser diretriz: "dissuadir a concentração de forças hostis" [...] "nos limites das águas jurisdicionais brasileiras".

O domínio do litoral é questão básica para a salvaguarda da soberania e da independência nacional. Lembrou-nos KAPLAN (2010, p. 37), que:

\begin{abstract}
Nicholas Spykman, o especialista em geopolítica do século XX, observou que, ao longo da história, os Estados têm se empenhado em 'expansão ultramarina e circunferêncial' para ganhar controle dos mares adjacentes. A Grécia buscou controle sobre o Mar Egeu, Roma sobre o Mediterrâneo, os Estados Unidos sobre o Caribe - e agora a China sobre o Mar da China do Sul. Spykman denominou o Caribe 'o Mediterrâneo Americano' para ressaltar a sua importância para os Estados Unidos (tradução nossa).
\end{abstract}

O Brasil possui posição geográfica central, em termos de poder naval, junto ao Atlântico Sul, o que torna esta área nosso espaço de prioridade estratégica. Potências extrarregionais, num contramovimento - ou melhor, num movimento relacionado à contenção da ascensão estratégica do Brasil - passam a buscar um reforço de suas posições no Atlântico Sul. Exemplo recente e de grande envergadura foi a reformulação da orientação estratégica da OTAN, decidida em Lisboa em 2010, que guiada pela exótica tese da Bacia Atlântica, passou a considerar o mare nostrum brasileiro - e mais amplamente - sul-americano e africano ocidental sua área de atuação - a despeito de aqui não haver, evidentemente, nenhum membro desta coalizão militar.

O que há no Atlântico Sul - resquício de uma era colonial que supostamente já deveria ter ido longe - é, para usar a expressão naval chinesa, um "cordão de ilhas" colonizadas por potências extrarregionais, no caso, a Grã-Bretanha, ativo membro da OTAN e do ponto de vista estratégico, umbilicalmente vinculada aos Estados Unidos. A ideia de "manter o inimigo longe de nossas costas", chave no pensamento mahaniano, dá conta da vulnerabilidade representada por esta incomoda presença, sobretudo num contexto em que se declara doutrinariamente a expansão da área da OTAN para nossa costa atlântica. 
Assim, dada à conformação física brasileira, de maritimidade, é preciso tornar mais explicito, no que diz respeito ao pensamento estratégico, esta vulnerabilidade estratégica central.

É evidente, pois, que iniciativas militares, num cenário de confrontação aguda de interesses nacionais brasileiros com potências exógenas, poderiam ter como fonte o Atlântico Sul, a partir das ilhas (verdadeiros porta-aviões fundeados) em que tropas da OTAN se baseiam.

A ocupação territorial estrangeira de um grande país, com grande população, é tarefa muito difícil, custosa, tanto em termos materiais como humanos. Sobretudo, ressalte-se, num contexto em que o Brasil passa a se preparar abertamente para a possibilidade de uma guerra de resistência nacional num cenário extremo de agressão de potências extrarregionais. Literalmente, a Estratégia Nacional de Defesa considera que a possibilidade de "guerra assimétrica, no quadro de uma guerra de resistência nacional, representa uma efetiva possibilidade da doutrina aqui especificada" (END, 2012, p.15).

Assim, o risco maior parece vir pelo mar, tendo como base de apoio este cordão de ilhas da OTAN que nos circunda no Atlântico Sul, combinado com possíveis tentativas de destruição da infraestrutura econômica, cientifica e tecnológica, ademais de bens e ativos sensíveis, provavelmente por via aérea, como tem se caracterizados as guerras contemporâneas.

Na América do Sul, em sua parte sul, prevalece - e provavelmente prevalecerá por longo período - relações de cooperação, ao mesmo tempo em que a presença estratégico-militar de potências extrarregionais diminui - a despeito de movimentos recentes, especialmente norte-americanos, de franquear bases à sua utilização na Colômbia; renovar acordos militares com países como Perú e Uruguai, e até ter lhe sido oferecida, por forças ligadas ao governo golpista do Paraguai, de uma base permanente no país. O fato é que na parte norte do subcontinente, há uma ofensiva perene, por parte dos Estados Unidos, com vistas a garantir posições estratégico-militares - em especial em países mais vulneráveis e dependentes.

Um problema adicional, e talvez ainda mais complexo, na dimensão terrestre, é o fato de ser justamente o Brasil, o país que faz a principal fronteira francesa, na Guiana 
francesa - uma enorme base da União Europeia fincada em plena Amazônia e em nossas fronteiras terrestres.

Entretanto, as barreiras físicas existentes, como a Cordilheira dos Andes e a vastidão da Amazônia, torna pouco provável uma ocupação por terra - eis o nosso inexpurgável heartland, para usar uma linguagem mackinderiana. Nesse sentido, nossa necessidade por terra refere-se mais a de monitoramento e controle - daí a iniciativa do Sisfron -, e de aumentar a presença do Estado, do que propriamente de um cenário de invasão por terra.

Além disso, contamos aqui com o legado do Barão do Rio Branco: não temos problemas de fronteira com nenhum dos nossos vizinhos, a despeito de sermos o terceiro país do mundo em número de vizinhos.

Assim, no que parece dar razão à Mahan, é preciso reforçar a Armada contra ameaças vindas do mar. Um bom início é a decisão estratégica (Cf. LBDN, 2012, p. 196) de ampliar em aproximadamente $80 \%$ os efetivos da Marinha, que irá dos atuais 65.528 para 115.370. Entretanto, este incremento, lento, tem como horizonte o longínquo ano de 2030.

Como dissemos anteriormente, na formulação de Hipótese de Emprego, se considera a possibilidade de uma guerra no Atlântico Sul. É premente dar consequência a isto, considerando inclusive às recomendações de Mahan sobre a importância de termos bases de operação ou postos avançados fora de nosso território físico. Antes de mais nada, no próprio Atlântico Sul, que defronta nosso território e, como se vê, é altamente vulnerável.

Eventualmente, poderíamos projetar força naval no Atlântico Sul, constituindo bases navais de porte na ilha de Trindade - com a bacia do Pré-sal localizada entre esta ilha e o continente, aproximadamente -, numa possibilidade, aliás, aventada pela Marinha, mas, todavia, não decidida. Ao norte, há o território de Fernando de Noronha . Além disso, numa situação ideal, em termo estratégico-militar, poderia ser desenvolvida uma solução técnica que permitisse uma base naval no Arquipélago de São Pedro e São Paulo - mirando, por exemplo, o que fazem pequenos países do Oriente Médio que expandem seu território artificialmente. 
Também, do "outro lado do rio", chamado Oceano Atlântico, é necessário intensificar a cooperação - por exemplo, realizar parceria com a Marinha da Namíbiaque se traduza, num futuro breve, em franqueamento de acesso da Armada brasileira à bases navais da costa oeste africana. É válido lembrar, entretanto, que a cada iniciativa, em relação a nosso entorno geoestratégico, há contramovimentos das potências centrais - por exemplo, vide a recente campanha de agências de notícias de países centrais a respeito do "imperialismo brasileiro" na África.

Do ponto de vista do poder naval, o Brasil deve dar importância estratégica superior às relações com o continente africano. Por exemplo, como desconsiderar a hipótese de emprego, num caso extremo, a necessidade de bloquear o que no Livro Branco é denominado de "garganta atlântica".

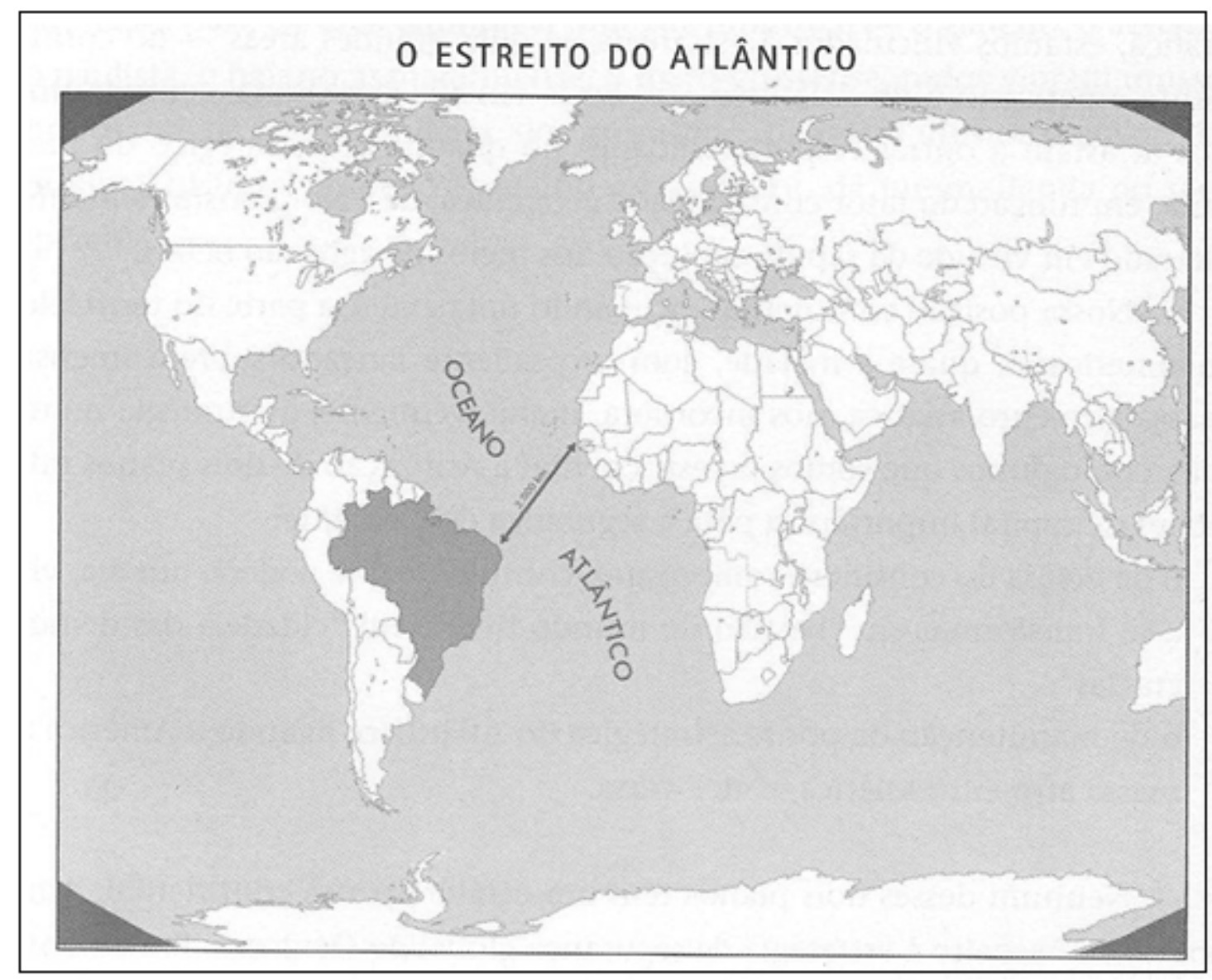

MAPA 14. Fonte: Meira Mattos, p. 44. Geopolítica. Rio de Janeiro: Editora FGV, 2011. 
Ressalte-se aqui, que a possibilidade desta decisão brasileira, de ter franqueado acesso à bases "do outro lado do rio", nada teria a ver com as razões que levam as potências coloniais a manterem bases muito distantes de seus países - ou o fato de os Estados Unidos possuírem comandos navais que cobrem toda a esfera global. No caso brasileiro, a projeção de poder tem a ver com o impedimento da imposição de vontades de outros, o que se faz, necessariamente, pela capacidade de dissuasão - aqui, compreendida não apenas como dissuasão defensiva, mas também ofensiva. Voltaremos a este tema.

O problema da descolonização do Atlântico Sul é questão estratégica chave, seja para o Brasil seja para a Argentina e o Uruguai, seja para os países do oeste da África. Essa deve ser uma questão central para a diplomacia brasileira.

Nesse sentido, é urgente um movimento que vise relançar e fortalecer a Zopacas - Zona de Paz e Cooperação do Atlântico Sul, ousada iniciativa brasileira que, entretanto, encontra-se numa situação de "banho-maria".

\section{Membros da Zopacas}

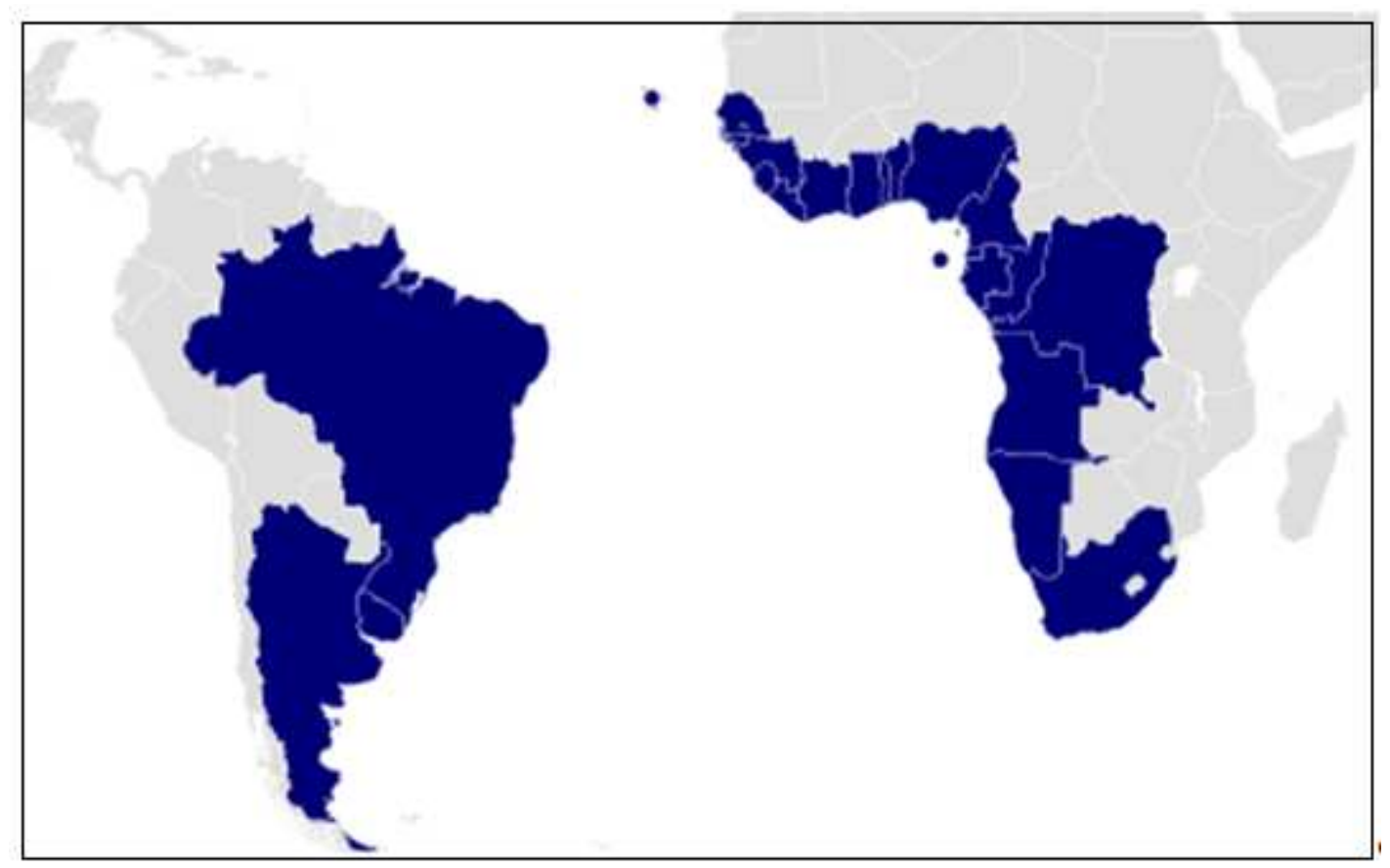

MAPA 15 
Chama atenção a dispersão e vulnerabilidade da África ocidental. Por exemplo, preocupa a ostensiva presença de forças estratégicas dos países centrais na região do Golfo da Guiné, rica em petróleo. Na Guiné Bissau, país irmão "de sangue" do Brasil, por exemplo, há um potente radar do Comando Africano dos Estados Unidos, embrião do que poderá ser uma importante base militar.

Dada a condição estratégica da África ocidental para o Brasil, nossa política em relação à eles se caracteriza pela extrema timidez ${ }^{94}$.

$\mathrm{Na}$ prospecção e mapeamento geológico do Atlântico Sul, é preciso, por exemplo, considerar em que medida as ilhas localizadas neste oceano configuram como certamente é o caso dos rochedos de São Pedro e São Paulo, ao norte, e das Ilhas Malvinas, em relação à Argentina, ao sul - a extensão do território sul-americano ou africano - no que permitiria, seja por razões históricas ou geológicas, reivindicar mais fortemente a exigência de soberania destes territórios, hoje nas mãos de potências extrarregionais.

O lançamento de uma ousada iniciativa brasileira - e sul-americana, em coordenação com a Argentina e o Uruguai -, por exemplo, relançando com todo peso político e econômico a Zopacas, é urgente. O próprio fato, discutido no capitulo III, do deslocamento do eixo geoestratégico para o Pacífico - a despeito, entretanto, da permanência da OTAN e sua expansão para o Atlântico Sul - pode representar uma margem maior para isto.

Nesta mesma chave de debate, o Brasil também precisa ter novo olhar estratégico para a CPLP (Comunidade de Países de Língua Portuguesa). Tendo como prioridade absoluta os cinco países da África ocidental (Angola, Guiné Bissau, Guiné Equatorial, São Tomé e Príncipe e Cabo Verde), o Brasil precisa expandir sua influência em Moçambique - localizado na estratégica costa oriental africana, base para salvaguardar interesses nacionais, nosso e dos países do hemisfério sul, sendo o Oceano Indico uma importante rota de comércio, inclusive para o Brasil. Também o Timor Leste - próximo ao novo centro geoestratégico naval, a região do Oceano Pacifico -,

${ }^{94}$ A despeito de haver sido, no governo Lula, relançada uma política africanista do Brasil, como ressaltam diversos analistas, como SOMBRA SARAIVA (2012) 
hoje alvo de investidas neocolonialistas da Austrália, precisa ter maior capacidade de iniciativa brasileira. Ademais, claro, de Portugal, país que num quadro de decadência europeia, pode voltar-se mais diretamente ao Brasil.

\section{O submarino a propulsão nuclear: meio para projetar poder no Atlantico, o mare nostrum}

Em termos do meio a empregar para a política atlântica do Brasil, a questão da projeção de poder por meio da Força de Submarinos, mais especificamente por parte do Submarino de propulsão nuclear, passa a ser uma questão chave no pensamento estratégico brasileiro, dada as características deste vetor.

Como dizem os oficiais da Marinha, trata-se de um "guerrilheiro do mar", dada sua capacidade de ocultação e surpresa. A decisão política e estratégica brasileira deveria prever a aceleração da construção deste artefato, previsto, hoje, para o relativamente distante ano de 2023. Afinal, como é ressaltado no Livro Branco (p.99), desde os anos 1970, "a Marinha constatou que dispor de submarinos convencionais não era suficiente para enfrentar possíveis ameaças no Atlântico Sul". Se isso foi uma verdade há 40 anos, que dirá hoje.

A descoberta das imensas reservas off shore petrolíferas e gasíferas do Pré-sal, coloca-nos, como país, numa excepcional posição estratégica no que diz respeito a questão energética, um dos problemas chave no cenário internacional do próximo período. Estas reservas nos levarão a uma verdadeira Marcha para o Leste, como disse recentemente um embaixador ${ }^{95}$, em alusão à célebre Marca para o Oeste, promovida pelo governo de Getulio Vargas.

A evidente vulnerabilidade desta riqueza salta aos olhos, sendo justificativa explícita para o relançamento da Armada, já que se justifica aumento de investimentos para proteger as plataformas petrolíferas. Como é apresentado no Livro Branco, há um salto exponencial dos gastos em investimentos com a Marinha, que precisa se

${ }^{95}$ Como denominou o embaixador Carlos Eduardo Cardim, no prefácio à PAIM, Maria Augusta. O Petróleo no Mar. Rio de Janeiro: Renovar Editora, 2011. 
incrementar. De R\$ 318 milhões de investimentos em 2006, passamos a R\$ 4, 165 bilhões em 2010 e R $\$ 2,840$ bilhões em 2011 (p. 230).

A Marcha para o Leste tem grande potencial para reforçar nossa maritimidade, característica e vocação (a rigor, desde os descobrimentos) de nossa formação social, que se potencializará pela existência deste fator objetivo - possibilidade de riqueza e prosperidade nacional.

\section{Questões de natureza estratégico-militar}

Por fim, mas não menos importante, há dois blocos de temas sobre relevantes questões de natureza estratégico-militar - quiçá, nesta dimensão, aspecto dos mais importantes em Mackinder e em Mahan.

O primeiro deles, caro ao pensamento mackinderiano, é a valorização da mobilidade, base de seu pensamento estratégico-militar. Para este autor, podemos dizer, a capacidade de domínio das vastas estepes eurasianas pelos mongóis e o acossamento dos europeus na periferia oeste da grande massa territorial se deu essencialmente por duas razoes, para além da questão geográfica em si: a posse de recursos naturais por um lado, e por outro, a enorme mobilidade de tropas movidas a cavalo.

Nas recentes definições estratégicas brasileiras, em especial na Estratégia Nacional de Defesa, documento que versa sobre os meios no processo de reequipamento e modernização das Forças, trata-se o problema da mobilidade como um tema chave não somente para o domínio do próprio território, mas também para projeção de poder.

Nas definições da END (seja na versão original, de 2008, seja na revista, de 2012), encontramos a seguinte definição sobre a importância do fator mobilidade:

A mobilidade estratégica - entendida como a aptidão para se chegar rapidamente ao teatro de operações - reforçada pela mobilidade tática entendida como a aptidão para se mover dentro daquele teatro - é o complemento prioritário do monitoramento/controle e uma das bases do poder de combate, exigindo das Forças Armadas ação que, mais do que conjunta, seja unificada.

O imperativo de mobilidade ganha importância decisiva, dadas a vastidão do espaço a defender e a escassez dos meios para defendê-lo. O esforço de presença, sobretudo ao longo das fronteiras terrestres e nas partes mais estratégicas do litoral, tem limitações intrínsecas. É a mobilidade que permitirá superar o efeito prejudicial de tais limitações (END, 2012). 
Em seguida, se discute a importância dos meios para efetivar a mobilidade. Assim, "mobilidade depende de meios terrestres, marítimos e aéreos apropriados e da maneira de combiná-los. Depende, também, de capacitações operacionais que permitam aproveitar ao máximo o potencial das tecnologias do movimento". (END, p.3, versão 2012).

Estas definições têm implicações latentes para as três Forças. Para a Marinha, que por definição tem seus meios de deslocando de forma mais lenta, tendo em vista o contato com a água, a prioridade passa a ser o mais veloz dos vetores marítimos, o submarino a propulsão nuclear.

Para o Exército, se especifica a importância do imperativo da mobilidade para o reequipamento da Força:
O entendimento da mobilidade tem implicações para a evolução dos blindados, dos meios mecanizados e da artilharia. Uma implicação desse entendimento é harmonizar, no desenho dos blindados e dos meios mecanizados, características técnicas de proteção e movimento. Outra implicação - nos blindados, nos meios mecanizados e na artilharia - é priorizar o desenvolvimento de tecnologias capazes de assegurar precisão na execução do tiro" (END 2012, p.14).

Por fim, a Força Aérea passa a ter papel essencial no fator mobilidade - esta questão não estava totalmente presente quando da primeira conferência de Mackinder; na época, o fator de modernização da mobilidade era a emergência de ferrovias, meio importante também para o deslocamento estratégico.

Para a FAB, a END propõe papel chave no fator mobilidade:

\begin{abstract}
A primeira implicação é a necessidade de dispor de aviões de transporte em número suficiente para transportar em poucas horas uma brigada da reserva estratégica, do centro do País para qualquer ponto do território nacional. As unidades de transporte aéreo ficarão baseadas no centro do País, próximo às reservas estratégicas da Força Terrestre" (END 2012, p.17).
\end{abstract}

Para a efetivação deste preceito, grande importância terá o avião de transporte de tropas KC-390, atualmente em desenvolvimento pela Embraer. De tecnologia nacional, substituirá o Hércules C-130, de fabricação norte-americana, representando um salto de qualidade no fator mobilidade das Forças Armadas, permitindo, assim, o deslocamento de uma importante quantidade de tropas em poucas horas a qualquer ponto do território nacional e também, em alguma medida, ao exterior. 
Uma segunda questão de corte estratégico militar, refere-se à defesa, medular no pensamento de Mahan sobre a importância da Armada possuir postura ofensiva. Para não alongar demasiado estas conclusões é desnecessário retornar aos argumentos do almirante norte-americano, detalhado no capitulo correspondente. Mas discutamos esta orientação mahaniana vis-à-vis com a estratégia brasileira.

Com todas as letras, lê-se no LBDB, p. 100, que "a Marinha deverá atuar, prioritariamente, dentro de uma postura estratégica defensiva". Afinal, do que vale para as três Forças, o Brasil adotar uma "postura estratégica dissuasória".

Segundo ROCHA PAIVA (2012, p. 322-323), em primeiro lugar, a dissuasão pode ser nuclear ou convencional. Sendo convencional, esta pode

\begin{abstract}
optar por uma postura dissuasória ofensiva ou defensiva. A primeira implica disposição e capacidade para revidar ou mesmo antecipar-se a uma agressão, atuando não só contra forças militares inimigas como também contra outros interesses e bens, inclusive não diretamente envolvidos no conflito. (...) A segunda está mais restrita à disposição e capacidade de deter ou revidar a agressão do oponente dentro de um teatro de operações ou agindo sobre o objetivo onde ela se concretize.
\end{abstract}

Cabe dizer que a teoria da dissuasão surgiu no contexto da guerra fria, diante da possibilidade, pelo uso de armas nucleares, de destruição mútua assegurada entre as duas grandes potências, o que gera efeito claro de dissuasão, isto é, uma das partes não usará por que se o fizer ambos os lados se destruirão mutuamente.

O Brasil fez a opção de não possuir vetor nuclear, inserindo esta proibição em sua Constituição. Mas ao fazê-lo, não abdicou de adquirir capacidade em termos de conhecimento para, num outro contexto, a partir de decisão politico-estratégica da sociedade brasileira, mudar de opinião. O domínio do ciclo completo do combustível nuclear e o desenvolvimento de artefatos espaciais nos colocarão em condições de reverter a decisão, se for o caso, para proteger-se de ambiente de franca deterioração nas relações internacionais.

Hoje, portanto, a estratégia do Brasil, de natureza dissuasória, é realizada por meios convencionais.

Como dissemos, o Brasil é um país territorialmente satisfeito, não tem objetivos expansionistas ou imperialistas, no que seria uma contradição com a própria natureza de nossa formação social. Mas tampouco isso quer dizer que devamos aguardar, passivos, 
avolumar-se ameaças contra a soberania e a integridade nacional, num ambiente internacional de luta por posições e crescentemente em deterioração.

O Brasil deve ser proativo estrategicamente. Ser passivo - ou defensivo poderia ser tarde demais no caso de uma agressão ao país de potência com poder de fogo altamente superior ao nosso.

A prioridade conferida a construção do Submarino a propulsão nuclear é o melhor exemplo de como uma postura defensiva pode rapidamente ser convertida em postura ofensiva, a partir de decisão estratégica nacional. Como um "guerrilheiro do mar", tendo em vista seu poder de ocultamento e ataque surpresa, pode paralisar toda uma esquadra inimiga que nos ouse atacar. O exemplo clássico disto é o uso, pelos ingleses na Guerra das Malvinas deste artefato, que impediu que os argentinos utilizassem sua Armada. Segundo o Almirante Othon Silva,

com a chegada dos submarinos nucleares às zonas de conflito, os britânicos estabeleceram uma Zona de Exclusão Total (ZET) de 200 milhas marítimas $(370 \mathrm{~km})$ de raio em torno das ilhas, o que negou o uso do mar aos argentinos numa região muito próxima ao seu país ${ }^{96}$ (SILVA, 1994, p. 26).

O Submarino, pois, demonstra que a linha que divide uma postura defensiva da ofensiva é bastante tênue. Assim, a postura brasileira parece ser somente a de não declarar o que está, de fato, ao alcance das mãos. Mas para isso, imprescindível é a viabilização de meios e equipamentos que permitam uma ou outra postura, a depender da evolução e do curso do cenário estratégico.

\section{Por um projeto de nação: “os reis passavam, mas a política naval permanecia"}

A atualização do pensamento estratégico brasileiro tem o potencial de realizar uma ampla convocação nacional pela grandeza da nação, que será derivada da realização de suas grandes potencialidades nacionais.

Aqui, para finalizar, cabe retomar o debate proposto por Mahan sobre o "caráter do governo", no qual o autor nos apresenta questões chaves.

\footnotetext{
${ }^{96}$ SILVA, Othon Luiz Pinheiro da. Submarino de propulsão nuclear no Brasil. Revista do Clube Naval, 1994. p. 26.
} 
Afirma, referindo-se a centralidade da questão naval para a própria existência da nação inglesa, que "os reis passavam, mas a política naval permanecia".

O desafio de um projeto nacional que consagre a busca por autonomia estratégica e geopolítica do Brasil, no terreno das nações, é o grande desafio posto para o povo brasileiro. Este mais será exitoso, na medida em que se estruture de forma mais perene como objeto de coesão dos brasileiros, em torno de um projeto de futuro, de uma causa coletiva comum. Este é o desafio da geopolítica brasileira e do pensamento estratégico nacional ao ingressarmos na segunda década do século XXI.

A geopolítica brasileira, pela natureza de nosso povo e de nossa formação social, não possui características expansionistas. Somos um povo territorialmente satisfeito com o território conquistado basicamente no período colonial. Como podemos observar no primeiro parágrafo da Estratégia Nacional de Defesa $(2012$, p.):

O Brasil é pacífico por tradição e por convicção. Vive em paz com seus vizinhos. Rege suas relações internacionais, dentre outros, pelos princípios constitucionais da não intervenção, defesa da paz e solução pacífica dos conflitos. Esse traço de pacifismo é parte da identidade nacional e um valor a ser conservado pelo povo brasileiro.

Tendo esta lógica como pressuposto, não é, entretanto, ingênuo, saber que para realizar seu projeto nacional de desenvolvimento precisa ter capacidade de contraditar quem ouse desafiar a soberania e a independência nacional. 


\section{BIBLIOGRAFIA}

ALMEIDA PINTO, J. R. de. (Org.). Reflexões sobre defesa e segurança: uma estratégia para o Brasil. Brasília: Ministério da Defesa, 2004 (Pensamento brasileiro sobre defesa e segurança). 4 volumes.

ALMEIDA, Francisco Eduardo Alves de. Alfred Thayer Mahan: o homem. Revista Marítima Brasileira, Rio de Janeiro, v. 129, n. 04/06, p. 147-173, abr./jun. 2009a.

A história segundo Alfred Thayer Mahan. Revista Marítima Brasileira, Rio de Janeiro, v. 129, n. 07/09, jul./set. 2009b.

Alfred Mahan e os elementos do poder marítimo. Revista Marítima Brasileira, Rio de Janeiro, v. 129, n. 10/12, out./dez. 2010.

. Alfred Thayer Mahan e os princípios da Estratégia Naval. Revista Marítima Brasileira, Rio de Janeiro, v. 130, n. 01/03, jan./mar. 2010.

Alfred Thayer Mahan e a Geopolítica. Revista Marítima Brasileira, Rio de Janeiro, v. 130, n. 04/06, abr./jun. 2010.

AMADO, Rodrigo. (Org.). Araujo Castro. Brasília: Editora Universidade de Brasília, 1982.

ANDRADA E SILVA, José Bonifácio. Obras científicas, políticas e sociais (3 tomos). Brasília: Câmara dos Deputados, 2006.

ARON, Raymond. Paz e guerra entre as nações. Brasília: Editora Universidade de Brasília, 1986.

AYERBE, Luis Fernando. De Clinton a Obama: política dos Estados Unidos para a América Latina. São Paulo: Editora Unesp, 2009.

BACKHEUSER, Everardo. A geopolítica geral e do Brasil. Rio de Janeiro: Biblioteca do Exército Editora, 1952.

BAUMANN, Ricardo. (Org.). O Brasil e os demais BRICs: comércio e política. Brasília: Cepal/IPEA, 2010.

BATISTA JÚNIOR, Paulo Nogueira. Paulo Nogueira Batista: pensando o Brasil. Brasília: Fundação Alexandre de Gusmão, 2009.

BARBOSA, Rubens. Mercosul e a integração regional. São Paulo: Fundação Memorial - Imprensa Oficial, 2009.

BARRIOS, Miguel Angel. Diccionario latinoamericano de seguridad y geopolitica. Buenos Aires: Editorial Biblos, 2009.

BEAUFRE, André. Introdução à estratégia. Rio de Janeiro: Biblioteca do Exército Editora, 1998. 
BECKER, Berta. Geografia: Manual do Candidato. Brasília: Fundação Alexandre de Gusmão, 2010.

BONFIM, Uraci Castro. Geopolítica. Brasília: Escola de Comando e Estado-Maior do Exército, 2005.

BRASIL. Livro Branco de Defesa Nacional - LBDN. Brasília, 2012. Disponível em: https://www.defesa.gov.br/arquivos/2012/mes07/lbdn.pdf Acessado em 01 nov 2012

BRASIL. Estratégia Nacional de Defesa - END. Brasília, 2012. Disponível em: https://www.defesa.gov.br/arquivos/2012/mes07/end.pdf Acessado em 01 nov 2012

BRASIL. Estratégia Nacional de Defesa - END. Brasília, 2008. Disponível em: http://www.defesa.gov.br/projetosweb/estrategia/arquivos/estrategia_defesa_nacional_p ortugues.pdf Acessado em 01 nov 2012

BRASIL. Política Nacional de Defesa - PND. Brasilia, 2012. Disponível em: https://www.defesa.gov.br/arquivos/2012/mes07/pnd.pdf Acessado em 01 nov 2012

BRASIL. Política de Defesa Nacional - PDN. Brasilia, 2005. Disponível em http://www.planalto.gov.br/ccivil_03/_Ato2004-2006/2005/Decreto/D5484.htm

Acessado em 01 nov 2012

BRASIL. Política de Defesa Nacional - PDN. Brasilia, 1996. Disponível em http://www.casacivil.gov.br/ Acessado em 01 nov 2012

BRASIL. Doutrina Militar de Defesa. Brasilia, 2007.

BRZEZINSKI, Zbigniew. El gran tablero mundial: la supremacia estadunidense y sus imperativos geoestratégicos. Barcelona: Paidós, 1998.

EUA - URSS: o grande desafio. Rio de Janeiro: Editorial Nordica, 1986.

. Strategic Vision. America and the crisis of global Power. New York: Basic Books, 2012.

CABRAL, Severino. Brasil, megaestado: nova ordem mundial multipolar. Rio de Janeiro: Editora Contraponto, 2004.

CARMONA, Ronaldo. O Brasil esboça sua "grande estratégia" - notas sobre a Política, a Estratégia e o Livro Branco de Defesa Nacional. Revista Princípios, São Paulo, n. 121, p. 14-21, out./Nov. 2012

Revisitando a teoria geopolítica clássica: permanências e descontinuidades em Mahan e Mackinder. São Paulo, 2011.

Desafios e dilemas na política externa brasileira. Revista Princípios, São Paulo, n. 108, p.58-64, jul./ago. 2010 b. 
O surgimento do Conselho de Defesa Sul-americano: relevante novidade para os estudos estratégicos contemporâneos. São Paulo, 2010a.

- Reações ao protagonismo brasileiro e a união sul-americana. Revista Princípios, São Paulo, n. 104, p.69-75, nov./dez. 2009.

A ameaça do terrorismo e o caso do Afeganistão: algumas aproximações teóricas e políticas. São Paulo, 2009.

- Elementos introdutórios ao debate teórico e contemporâneo sobre nãoproliferação de armas nucleares. São Paulo, 2009

Crises e conflitos num mundo em transição. Revista Princípios, São Paulo, n. 98, out./nov. 2008b.

Contra-ofensiva imperialista: contexto da agressão colombiana ao Equador. Revista Princípios, São Paulo, n. 95, abr./maio 2008a.

Características da nova luta pelo socialismo na América Latina. Revista Princípios, São Paulo, n. 92, out./nov. 2007.

Ciclo progressista e luta pelo socialismo na América Latina. Revista Princípios, São Paulo, n. 88, fev./mar. 2007.

. Formação social Brasileira: uma introdução ao debate. 2006. Trabalho de Conclusão de Curso (Sociologia e Política) - Escola de Sociologia e Política de São Paulo, São Paulo, 2006.

A nacionalização do gás boliviano e a (re)emergência da questão nacional. Revista Princípios, São Paulo, n. 85, jun. 2006.

América Latina: na luta pela segunda independência. Revista Princípios, São Paulo, n. 83, fev./mar. 2006.

Comunidade Sul-americana de Nações: progressos e obstáculos. Revista Princípios, São Paulo, n. 76, dez. 2004/jan. 2005.

CARVALHO, Delgado de; CASTRO, Therezinha de. Atlas de relações internacionais. Rio de Janeiro: IBGE/Conselho Nacional de Geografia, 1960.

Record, 1971.

Relações internacionais. Rio de Janeiro: Biblioteca do Exército e Distribuidora

CASTRO, Therezinha de. Geopolítica: princípios, meios e fins. Rio de Janeiro: Biblioteca do Exército Editora, 1999.

Nossa América: geopolítica comparada. Rio de Janeiro: Biblioteca do Exército Editora, 1994. 
Editora, 1984.

José Bonifácio e a Unidade Nacional. Rio de Janeiro: Biblioteca do Exercito

COSTA FREITAS, Jorge Manoel. A escola geopolitica brasileira. Rio de Janeiro: Biblioteca do Exercito Editora, 2004.

COSTA, Darc. Fundamentos para o estudo da estratégia nacional. São Paulo: Editora Paz e Terra, 2009.

Estratégia Nacional: A cooperação sul-americana como caminho para a inserção internacional do Brasil. Rio de Janeiro: Editora L\&PM Editores, 2003.

COSTA FRANCO, Álvaro de. Documentos da política externa independente. Brasília: Fundação Alexandre de Gusmão, 2007 e 2008. 2 v.

COSTA, Wanderley Messias da. Geografia política e geopolítica. São Paulo: Edusp, 2008.

COUTO E SILVA, Golbery. Geopolítica do Brasil. Rio de Janeiro: Editora José Olympio, 1967.

Conjuntura política nacional: o poder executivo e geopolítica do Brasil. Rio de Janeiro: Editora José Olympio, 1981.

DALLIN, Alexander (Org.). A conduta soviética nas relações internacionais. Rio de Janeiro: Edições GRD, 1964.

DEL VECCHIO, Ângelo. (Org.). Brasil e Estados Unidos no contexto da globalização. São Paulo: Editora Sociologia e Politica, , 2010.

DOUHET, Giulio. O domínio do ar. Rio de Janeiro: Instituto Histórico Cultural da Aeronáutica, 1988.

DONADIO, Marcela; TIBLIETTI, Maria da Paz. Atlas 2012. Buenos Aires: RESDAL, 2012.

DINIZ, Eugenio. Política internacional: guia de estudos das abordagens realistas e da balança de poder. Belo Horizonte: Editora PUC Minas, 2007.

PROENÇA JÚNIOR, Domício; RAZA, Salvador Ghelfi. Guia de estudos de estratégia. Rio de Janeiro: Jorge Zahar Editor, 1999.

ESCOLA SUPERIOR DE GUERRA. O General Meira Mattos e a Escola Superior de Guerra. Rio de Janeiro, ESG, 2007.

ESTATÍSTICAS. Brasília: Fundação Alexandre de Gusmão, 2009. 
FERREIRA SIMÕES, Antonio José. Integração: sonho e realidade na América do Sul. Brasília: Fundação Alexandre de Gusmão, 2011.

FERREIRA VIDIGAL, Armando Amorim. et al. Amazônia azul: o mar que nos pertence. Rio de Janeiro: Editora Record, 2006.

FIORI, José Luís. Guerra na África é nova corrida imperialista, diz especialista. Folha de S. Paulo, São Paulo, 04 abr. 2011. Disponível em: <http://www1.folha.uol.com.br/mundo/896777-guerra-na-africa-e-nova-corrida-imperialistadiz-especialista.shtml>. Acesso em: 04 abr. 2011.

Caleidoscópio mundial. Valor Econômico, cidade, 29 dez. 2010, p. A13. Disponível em: <http://www.valor.com.br/arquivo/864997/caleidoscopio-mundial>. Acesso em: dia mês abreviado ano.

; MEDEIROS, Carlos; SERRANO, Franklin. $O$ mito do colapso do poder americano. Rio de Janeiro: Editora Record, 2008.

O poder global e a nova geopolítica das nações. São Paulo: Boitempo Editorial, 2007.

FONSECA JR., Gelson. A Legitimidade e outras questões internacionais. São Paulo: Editora Paz e Terra, 2004.

FREYRE, Gilberto. Casa grande e senzala: introdução à história da sociedade patriarcal no Brasil. Rio de Janeiro: Editora Record, 1998.

1949.

Nação e exército. Rio de Janeiro: Livraria José Olympio Editora,

FRIEDMAN, George. Os próximos 100 anos: uma previsão para o século XXI. Editora Rio de Janeiro: Best Business, 2009.

GLOBAL GOVERNANCE 2025: AT A CRITICAL JUNCTURE, de setembro de 2010, publicado pelo National Intelligence Council do governo norte-americano. Disponível em: <http://www.dni.gov/nic/PDF_2025/2025_Global_Governance.pdf>. Acesso em: 01 dez. 2010.

GUIMARÃES, Samuel Pinheiro. Quinhentos anos de periferia. Porto Alegre/Rio de Janeiro: Editora da Universidade UFRGS/Contraponto, 1999.

Desafios brasileiros na era de gigantes. Rio de Janeiro: Contraponto, 2005.

GUGLIALMELli, Juan Enrique. Geopolitica del cono sur. Buenos Aires: El Cid Editor, 1979.

HONÓRIO RODRIGUES, José. Interesse nacional e política externa. Rio de Janeiro: Editora Civilização Brasileira, 1966. 
HUGON, Philippe. Geopolítica da África. Rio de Janeiro: Editora FGV, 2009.

HUNTINGTON, Samuel P. O Choque de civilizações e a recomposição da ordem mundial. Rio de Janeiro: Biblioteca do Exército Editora, 1998.

JALIFE-RAHME, Alfredo. El hibrido mundo multipolar: un enfoque multidimensional. Ciudad de Mexico: Orfila, 2010.

JOBIM, Nelson; ETCHEGOYEN, Sergio W.; ALSINA, João Paulo. (Org.). Segurança Internacional: perspectivas brasileiras. Rio de Janeiro: Editora FGV, 2010.

KAGAN, Robert. El retorno de la Historia y el Fin de los Sueños. Ciudad de México: Taurus, 2008.

KANT, Immanuel. À paz perpétua. Porto Alegre: L\&PM Editora, 2008.

KAPLAN, Robert D. The geography of chinese power. Foreign Affairs, New York, v. 89 , n. 3, p. 22-41, maio/jun. 2010.

KENNEDY, Paul. Ascensão e Queda das Grandes Potencias: transformação econômica e conflito militar de 1500 a 2000. 2ed, Rio de Janeiro: Campus, 1989.

KHANNA, Parag. O Segundo mundo. São Paulo: Editora Intrínseca, 2008.

KISSINGER, Henry. Diplomacia. Lisboa: Gradiva, 2007.

O mundo restaurado. Rio de Janeiro: Livraria José Olympio Editora, 1973.

LACOSTE, Yves. Geopolítica: la larga história del presente. Madrid: Editorial Sintesis, 2008.

A geografia: isso serve, em primeiro lugar, para fazer a guerra. Campinas: Editora Papirus, 2010.

LENIN, Vladimir Ilitch. Obras escogidas. Moscou: Editorial Progreso, Moscou, 1981. $3 \mathrm{v}$.

LESSA, Carlos. A inferioridade brasileira: uma conveniente convicção da elite. Jornal Valor Econômico, 02 ago. 2006.

LESSA, Renato; BUARQUE DE HOLLANDA, Cristina. San Tiago Dantas: coletânea de textos sobre política externa. Brasília: Fundação Alexandre de Gusmão, 2009.

LIGTH, Kenneth. (Org.). A Transferência da capital e corte para o Brasil: 1807-1808. Lisboa: Editora Tribuna da História, 2007.

MACKINDER, Halford J. Democratic ideals and reality. New York: Henry Holt and Company, 1942. 
. El Mundo redondo y la conquista de la paz. In: WEIGERT, Hans W.; STEFANSSON, Vilhjalmur. (Org.). Politica y poder em um Mundo mas Chico. Buenos Aires: Editorial Atlântida, 1948.

. El eje geográfico de la Historia. In: RATTENBACH, Augusto B. (Org.). Antologia Geopolítica. Buenos Aires: Editorial Pleamar, 1985.

MAGNOLI, Demétrio. (Org.). História das guerras. São Paulo: Editora Contexto, 2006 .

História da paz. São Paulo: Editora Contexto, 2008.

MAFRA, Roberto Machado de Oliveira. Geopolítica: introdução ao estudo. São Paulo: Sicurezza Editora, São Paulo: 2006.

MAHAN, Alfred Thayer: The influence of sea power upon history: 1660-1805. Hong Kong: Prentice-Hall Inc., 1984.

MARTIN, André Roberto. Brasil, geopolítica e poder mundial: o anti-Golbery. 2007. 118 f. Tese (Tese de livre docência em Geografia Humana), Departamento de Geografia, Universidade de São Paulo, São Paulo. 2007.

.. Fronteiras e nações. São Paulo: Contexto, 1997.

MATHIEU, Hans; GUARNIZO, Catalina Niño. Anuário 2010 de la seguridad regional de América Latina y el Caribe. Bogotá: Friedrich Ebert Stiftung, 2010.

MEIRA MATTOS, Carlos de. Geopolítica e modernidade - geopolítica brasileira. Biblioteca do Exército Editora, Rio de Janeiro, 2002.

. Geopolitica y teoria de las fronteras. Buenos Aires: Circulo Militar, 1997.

. Geopolítica e trópicos. Rio de Janeiro: Biblioteca do Exército Editora, 1984.

. Uma geopolítica pan-amazônica. Rio de Janeiro: Biblioteca do Exército Editora, 1980.

A geopolítica e as projeções do poder. Rio de Janeiro: Biblioteca do Exército Editora, 1977.

1975.

Brasil, geopolítica e destino. Rio de Janeiro: Livraria José Olympio Editora,

Geopolítica. Rio de Janeiro: Editora FGV, 2011.

MELLO, Leonel Itaussu Almeida. Quem tem medo da geopolítica?. São Paulo: Editora Hucitec e EDUSP, 1999. 
Argentina e Brasil: a balança de poder no cone sul. São Paulo: Editorial Annablume, 1996.

MENZIE, Gavin. 1421: O ano em que a China descobriu o mundo. Tradução Maria Eduarda Colares. Lisboa: Dom Quixote, 2004.

MONIZ BANDEIRA, Luiz Alberto. Geopolítica e política exterior: Estados Unidos, Brasil e América do Sul. Brasília: Fundação Alexandre de Gusmão, 2009.

O Brasil como potência regional e a importância estratégica da América do Sul para sua política exterior. Disponível em: 〈www.amersur.com.ar〉. Acesso em: dia fev. 2009.

La importancia geopolítica de América del Sur, en la estratégia de los Estados Unidos. . Disponível em: 〈www.amersur.com.ar〉. Acesso em: dia fev. 2009.

MIYAMOTO, Shiguenoli. Geopolítica e poder no Brasil. São Paulo: Papirus Editora, 1995.

MORGENTHAU, Hans J. A política entre as nações: a luta pela guerra e pela paz. Brasília: Editora Universidade de Brasília/Instituto de Pesquisas de Relações Internacionais; São Paulo: Imprensa Oficial do Estado de São Paulo, 2003.

NATIONAL SECURITY STRATEGY. The White House, maio 2010. Disponível em: $<$ http://www.whitehouse.gov/sites/default/files/rss_viewer/national_security_strategy.p df $>$. Acesso em: 12 ago 2012

NYE JR. Joseph S. Cooperação e conflito nas relações internacionais. São Paulo: Gente editora, 2009.

OLIVEIRA, Eliézer Rizzo de (Org.). Segurança e Defesa Nacional: da competição à cooperação regional. São Paulo: Fundação Memorial da América Latina, 2007. 288p.

PAIM, Maria Augusta. O Petroleo no Mar. Rio de Janeiro: Renovar Editora, 2011.

PATRIOTA, Antonio de Aguair. O Conselho de Segurança após a guerra do golfo: a articulação de um novo paradigma de segurança coletiva. Brasília: Fundação Alexandre de Gusmão, 2010.

REBELO, Aldo. Raposa-Serra do Sol: o índio e a questão nacional. São Paulo: Editora Thesaurus, 2010.

; FERNANDES, Luís. Política de defesa para o século XXI. Brasília: Câmara dos Deputados, 2003.

; FERNANDES, Luís. Política externa do Brasil para o século XXI. Brasília: Câmara dos Deputados, 2003.

RIBEIRO, Darcy. O Povo brasileiro. São Paulo: Editora Schwarcz, 2006. 
ROCHA FILHO, Álvaro; GARCIA, João Carlos Vitor. Renato Archer: energia atômica, soberania e desenvolvimento - depoimento. Rio de Janeiro: Contraponto, 2006.

SANTOS, Milton. Por uma outra globalização: do pensamento único à consciência universal. São Paulo: Record, 2000.

SECRETARIA DE ASSUNTOS ESTRATÉGICOS. Brasil 2022. Brasília, 2010.

SELSER, Gregorio. Cronologia de las intervenciones estranjeras en América Latina. Quatro tomos, 1776-1990. Ciudad de Mexico: Universidad Autonoma de la Ciudad de Mexico, 2010.

SEVERSKY, Major A. P. A vitória pela força aérea. Belo Horizonte: Editora Itatiaia, 1988.

SILVA, Othon Luiz Pinheiro da. Submarino de propulsão nuclear no Brasil. Revista do Clube Naval, 1994.

SPEKTOR, Matias. Kissinger e o Brasil. Rio de Janeiro: Zahar Editora, 2009.

SPYKMAN, Nicholas J. Estados Unidos frente al mundo. Ciudad de Mexico: Fondo de Cultura Económica, 1944.

SOMBRA SARAIVA, José Flávio. África parceira do Brasil atlântico: relações internacionais do Brasil e da África no início do século XXI. Brasília: Editora Fino Traço, 2012.

TRAVASSOS, Mário. Projeção continental do Brasil. Rio de Janeiro: Livraria José Olympio Editora, 1938.

Introdução à geografia das comunicações brasileiras. Rio de Janeiro: Livraria José Olympio Editora, 1942.

TEIXEIRA DA SILVA, Francisco Carlos; CABRAL, Ricardo Pereira; MUNHOZ, Sidnei J. Impérios na história. Rio de Janeiro: Editora Campus, 2009.

VESENTINI, José William. Novas geopolíticas. São Paulo: Editora Contexto, 2008.

VIEIRA, Maria Graciana Espellet de Deus. Formação social brasileira e geografia: reflexões sobre um debate interrompido. 1992. Dissertação (Mestrado em Geografia) Centro de Ciências Humanas, Universidade Federal de Santa Catarina, Santa Catarina, 1992.

VILLA, Rafael Antonio Duarte. Da crise do realismo à segurança global multidimensional. São Paulo: Annablume Editora, São Paulo: 1999.

ZAKARIA, Fereed. O Mundo pós-americano. São Paulo: Companhia das Letras, 2008. 